\title{
FLUIDIZED BED STEAM REFORMING FOR TREATMENT AND IMMOBILIZATION OF LOW- ACTIVITY WASTE
}

\author{
W.M. Hewitt \\ YAHSGS LLC \\ Richland, WA 99352 \\ U.S. Department of Energy Contract DE-AC27-08RV14800 \\ EDT/ECN: \\ UC: \\ Cost Center: $2 \mathrm{GH} 00$ \\ Charge Code: 200993 \\ B\&R Code: \\ Total Pages: 75
}

Key Words: Low-Activity Waste, LAW, Fluidized Bed Steam Reforming, FBSR

Abstract: This report is one of four reports written to provide bacground information regarding immobilization technologies remaing under consideration for supplemental immobilization of Hanford's low-activity waste. This paper prvides the reader a general understanding of fluidized bed steam reforming and its possible application to treat and immobilize Hanford low-activity waste.

TRADEMARK DISCLAIMER. Reference herein to any specific commercial product, process, or service by trade name, trademark, manufacturer, or otherwise, does not necessarily constitute or imply its endorsement, recommendation, or favoring by the United States Government or any agency thereof or its contractors or subcontractors.

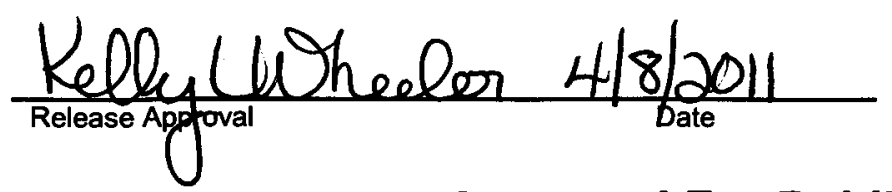

\section{Approved For Public Release}

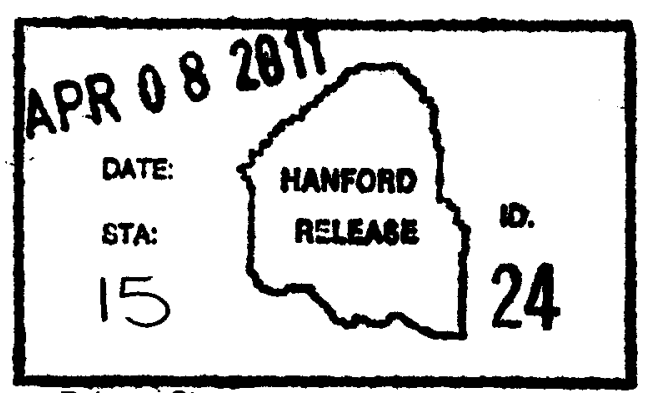

Release Stamp 
RPP-48903, Rev 0

\section{FLUIDIZED BED STEAM REFORMING FOR TREATMENT AND IMMOBILIZATION OF LOW-ACTIVITY WASTE}

Author:

W. M. Hewitt

YAHSGS LLC under Contract 37874, Release 4 to Washington River Protection Solutions, LLC

Date Published

April 2011

Prepared for the U.S. Department of Energy

Office of River Protection

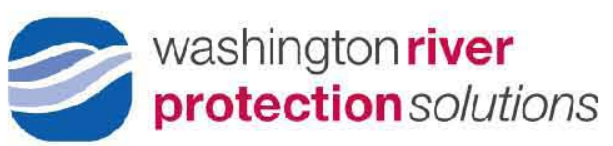

P. O. Box 850

Richland, Washington

This report was prepared as an account of work sponsored by an agency of the United States Government. Neither the United States Government nor any agency thereof, nor any of their employees, nor any of their contractors, subcontractors or their employees, makes any warranty, express or implied, or assumes any legal liability or responsibility for the accuracy, completeness, or any third party's use or the results of such use of any information, apparatus, product, or process disclosed, or represents that its use would not infringe privately owned rights. Reference herein to any specific commercial product, process, or service by trade name, trademark, manufacturer, or otherwise, does not necessarily constitute or imply its endorsement, recommendation, or favoring by the United States Government or any agency thereof or its contractors or subcontractors. The views and opinions of authors expressed herein do not necessarily state or reflect those of the United States Government or any agency thereof. 


\section{RPP-48903, Rev 0}

\section{PURPOSE}

The U.S. Department of Energy is building a Waste Treatment and Immobilization Plant to treat the approximately 55 million gallons of wastes from reprocessing spent nuclear fuel stored in 177 underground tanks at the Hanford Site in Washington State. Following treatment to remove key radionuclides to the maximum extent practical, approximately $90 \%$ of the tank waste mass (excluding water) will be immobilized as low-activity waste. The remainder will be immobilized as high-level waste.

The Waste Treatment and Immobilization Plant Low-Activity Waste Vitrification Plant should be capable of immobilizing approximately one-third of the total low-activity Hanford waste. A supplemental low-activity waste immobilization facility will be required to immobilize the remaining low-activity waste in order to complete the treatment mission on or before 2047 in accordance with the Hanford Federal Facility Agreement and Consent Order, which is also referred to in this report as the Tri-Party Agreement. Based on extensive reviews that started in 2002 by the Department of Energy, the Washington Department of Ecology, the U.S., the Environmental Protection Agency, and the Department of Energy contractors, four-candidate supplemental low-activity waste immobilization technologies remain under consideration.

1. Second Low-Activity Waste Vitrification Plant (RPP-48395, A Joule-Heated Melter Technology for the Treatment and Immobilization of Low-Activity Waste) (same technology as the LAW vitrification plant currently under construction).

2. Bulk Vitrification (RPP-48703, Bulk Vitrification Technology for the Treatment and Immobilization of Low-Activity Waste) (an in-container vitrification technology).

3. Cast Stone (RPP-49062, Cast Stone Technology for the Treatment and Immobilization of Low-Activity Waste) (a grout-based immobilization technology tailored to Hanford low-activity waste).

4. Fluidized Bed Steam Reforming (RPP-48903, Fluidized Bed Steam Reforming for Treating and Immobilizing Low-Activity Waste) (a thermal technology that produces a mineral waste form).

Four reports, as numbered above, have been prepared by Washington River Protection Solutions. Each report is designed to stand-alone or be used in conjunction with the others to provide background information about these technologies. The reports do not attempt to directly or indirectly recommend, compare, or contrast any one technology over the other. Rather, the goal is to present information as a high-level introduction to the four technologies, and assist the reader in further exploration of any given topic. Each of the reports will follow the same basic structure as outlined below.

- Common introduction providing background to the Office of River Protection mission.

- Introduction to the specific technology.

- Current state of knowledge for the technology.

- Current information needs.

- Risks and data needs.

- References. 
Note: The above sections are not numbered as each topic may require less or more sections to delineate the information on the topics.

This report is focused on Fluidized Bed Steam Reforming Technology.

The information in this report is primarily digested from scientific information published in the literature, vendor information, independent reports, and studies funded by DOE. Information from those sources is presented in this report in a format and style intended to be understandable by non-technical readers yet to also be informative to DOE, regulators, and other technically informed readers.

The intent of the document is to summarize information in an easily assimilated format with references to source documents. The intent is not to compare the merits of Fluidized Bed Steam Reforming to other technologies nor promote the use of Fluidized Bed Steam Reforming. The selection decision regarding which technology will be used in accordance with applicable DOE Orders, the National Environmental Policy Act, and the Tri-Party.

This report describes known data gaps, technical risks, and other issues to be addressed through waste form qualification test programs or through subsequent maturation tests or engineering studies.

It should be noted that discussions of these technologies are based on pre-conceptual design information. As such the level of design descriptions is intended to be general. Current and accurate cost information specific to each technology is not available. 


\section{EXECUTIVE SUMMARY FLUIDIZED BED STEAM REFORMING}

The U.S. Department of Energy is building a Waste Treatment and Immobilization Plant to treat the approximately 55 million gallons of wastes resulting from reprocessing irradiated nuclear fuel as part of the defense program. That waste is currently stored in 177 underground tanks at the Hanford Site in Washington State. Following treatment to remove key radionuclides to the maximum extent practical, approximately $90 \%$ of the tank waste mass (excluding water) will be immobilized as low-activity waste. The Department of Energy plans to immobilize and dispose of the low-activity waste stream on-site

The remainder of the tank waste, which will contain approximately $95 \%$ of the total tank waste radioactive inventory, will be vitrified as high-level waste. The vitrified high-level waste will be interim-stored on-site until a final disposal solution is identified. A simplified Hanford tank waste cleanup, treatment, and disposal flowsheet is depicted in Figure ES-1.

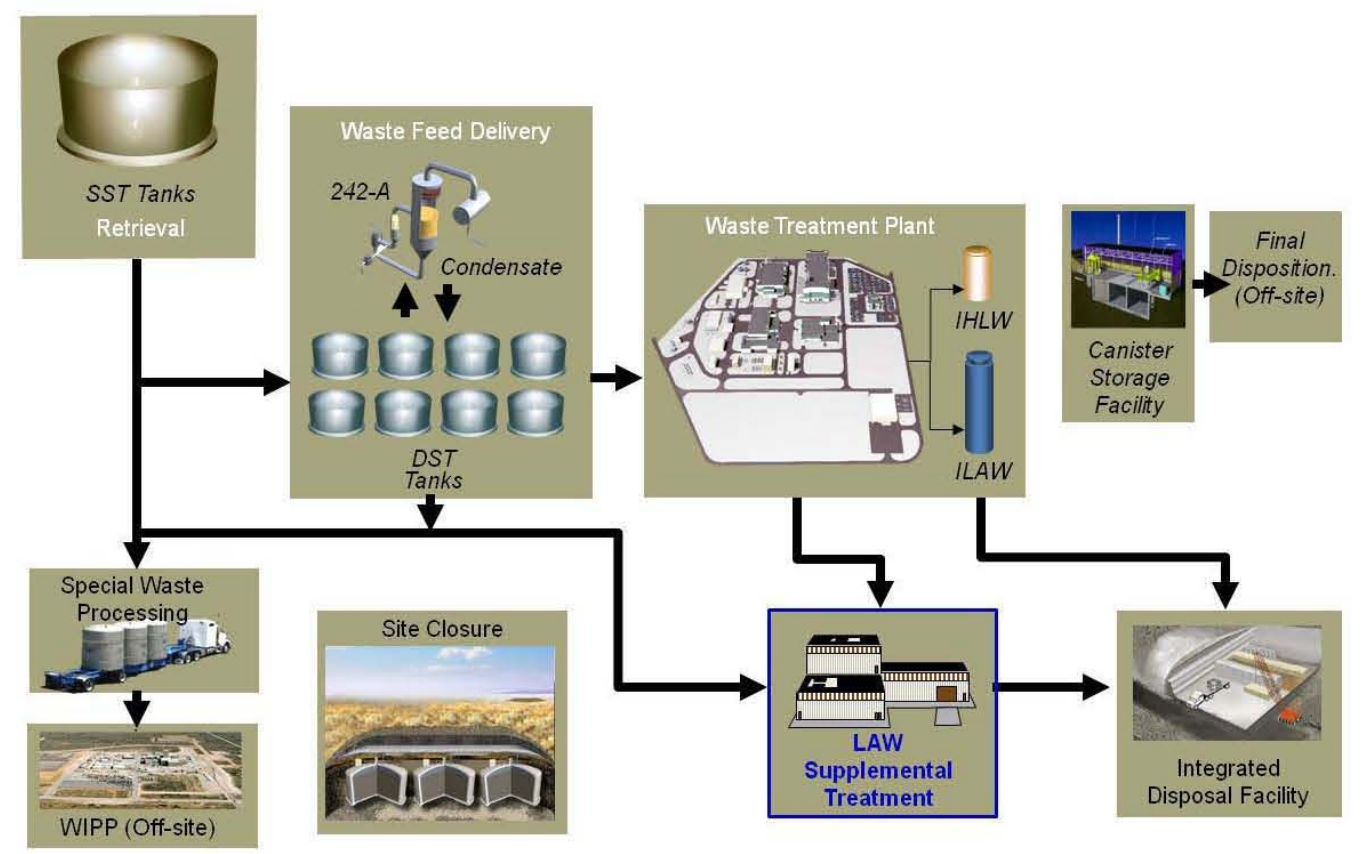

Figure ES-1. Hanford Nominal Tank Waste Treatment \& Disposition Flowsheet

The Waste Treatment and Immobilization Plant Low-Activity Waste Vitrification Plant should be capable of vitrifying approximately one-third to one-half of the total low-activity waste. Supplemental low-activity waste immobilization will be required to immobilize the remainder. The Hanford Federal Facility Agreement and Consent Order, which is also referred to in this report as the Tri-Party Agreement or TPA, requires all Hanford tank waste treatment and immobilization to be completed by 2047 .

Because waste retrieved from the tanks is separated into high-level waste and low-activity waste fractions during pretreatment, unless the low-activity waste can be immobilized at the rate at which it is produced, the pretreatment processing and high-level waste vitrification will operate below the nominal production capacity throughput required to complete the mission on or before 


\section{RPP-48903, Rev 0}

2047. Accordingly, the Department of Energy is currently considering ways to supplement the Waste Treatment and Immobilization Plant low-activity waste vitrification plant capacity in a manner that is protective of human health and the environment while also fiscally responsible.

Based on extensive reviews that started in 2002 by the Department of Energy, the Washington Department of Ecology, and the U.S. Environmental Protection Agency, four candidate supplemental low-activity waste immobilization technologies are under consideration:

1. Second Low-Activity Waste Vitrification Plant (same technology as currently in the WTP).

2. Bulk Vitrification (an in-container vitrification technology).

3. Cast Stone (a grout-based immobilization technology tailored to Hanford lowactivity waste).

4. Fluidized Bed Steam Reforming (a thermal technology that produces a mineral waste form).

The decision regarding which of the four candidate technologies will be ultimately deployed will be made in accordance with Department of Energy Orders, the National Environmental Policy Act, and the Tri-Party Agreement. It is not known as of this writing which of those technologies will be selected.

This report focuses on Fluidized Bed Steam Reforming. Similar reports are being developed for the other three technologies.

Steam reforming has been used for over 100 years in the chemical industry. Over the past decade the Fluidized Bed Steam Reforming process has been used commercially in Erwin, Tennessee to treat radioactive wastes. The Department of Energy has selected Fluidized Bed Steam Reforming to treat certain tank wastes at the Idaho National Laboratory and the Savannah River Site. The Integrated Waste Treatment Unit at Idaho National Laboratory is in the final stages of construction with commissioning scheduled to start in 2011.

The Fluidized Bed Steam Reforming process is essentially the same at each of these locations. The Hanford low-activity waste form will be made more durable than the waste forms used at the other sites by mixing clay with the low-activity waste feed and converting the waste feed/clay mixture to durable sodium aluminosilicate minerals in the Fluidized Bed Steam Reforming. Those minerals, principally nepheline and sodalites, are of the feldspathoid class of minerals.

The scientific literature indicates that the mineral waste form produced by Fluidized Bed Steam Reforming should perform comparably to low-activity waste glass-based on minerals produced from Hanford low-activity waste feed surrogates that were treated by Fluidized Bed Steam Reforming and tested using the same types of testing protocols that are used to predict long-term low-activity waste glass performance. The surrogate low-activity waste feeds were created to chemically mimic low-activity waste. 
In order to confirm Fluidized Bed Steam Reforming waste form suitability, Fluidized Bed Steam Reforming runs are also being conducted using actual Hanford low-activity waste wastes. Minerals created during those runs will be tested for durability to determine where technetium resides within the mineral, and to build correlations with results from surrogate tests (Figure ES-2). The runs with actual Hanford low-activity waste feed are scheduled for 2011 in the Savannah River National Laboratory Bench-Scale Reformer. Waste forms produced during the runs with

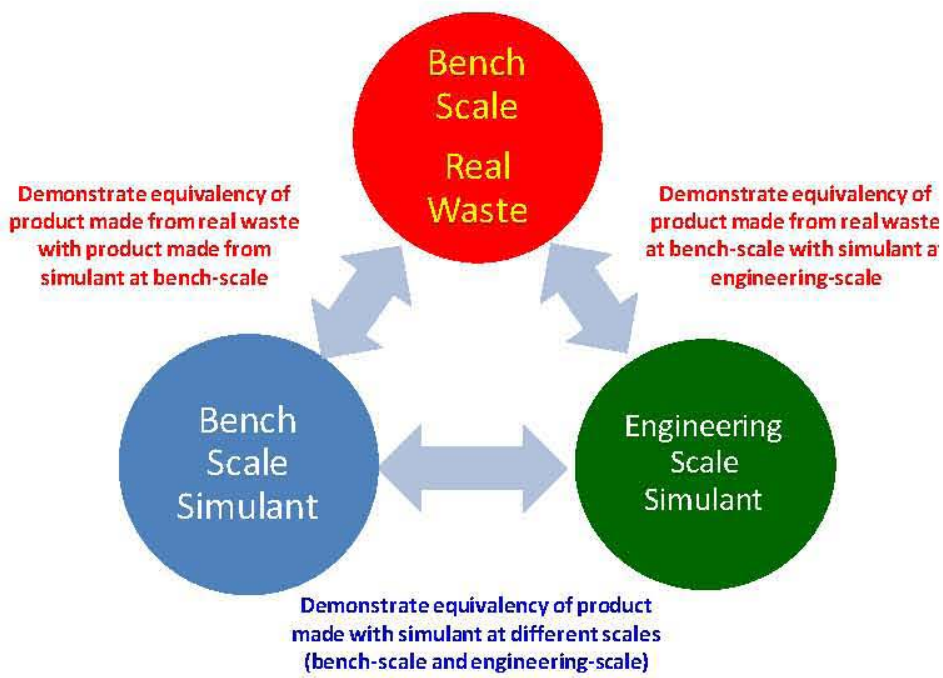

Figure ES-2. Testing with Actual Hanford Tank Waste Provides Important Correlations Necessary to Validate Results Obtained with Surrogate Wastes actual Hanford low-activity waste at SRNL in 2011 will undergo extensive durability testing at Savannah River National Laboratory, Pacific Northwest National Laboratories, and Oak Ridge National Laboratory.

The mineral waste form produced by Fluidized Bed Steam Reforming is a combination of mineral granules and fines, both of which have the same mineral properties. For disposal at Hanford the mineral product will be mixed with a binder to form solid monoliths. The binder material will be selected to be compatible with the minerals and to provide the compressive strength required for disposal in the Hanford Integrated Disposal Facility. Durability tests will be conducted on both the mineral product and the monolith waste forms. Data obtained will substantially enhance the current understanding of long-term durability, monolith performance, technetium placement within the mineral matrices, and the Fluidized Bed Steam Reforming material balance. The Department of Energy will make information resulting from those tests available to the Hanford regulators and stakeholders through reports and presentation materials.

Among the benefits reported in the literature to be associated with the Fluidized Bed Steam Reforming approach to low-activity waste treatment and immobilization are waste form durability; high capture percentages for radionuclides including technetium-99, cesium-137, and iodine-129; creation of Resource Conservation and Recovery Act-compliant waste forms; and moderate capital and operating costs.

The Fluidized Bed Steam Reforming process will face significant regulatory challenges as it matures through the Hanford regulatory and stakeholder acceptance processes. Notwithstanding a current strong preference for vitrified waste forms, Fluidized Bed Steam Reforming may provide a means to complement Waste and Immobilization Plant low-activity waste vitrification that results in lower net environmental and programmatic risk.

A number of questions remain to be satisfactorily answered regarding whether Fluidized Bed Steam Reforming is suitable for deployment at Hanford for low-activity waste immobilization. 
In general these questions are focused on obtaining mechanistic explanations that explain scientific observations (e.g., how are key radionuclides bound within the mineral matrices); closing material balances (e.g., accounting for where feed materials are in the waste, off-gas, or system following treatment); and increasing the overall level of confidence that the phenomena observed with surrogate low-activity waste feed at laboratory and engineering scales will translate into similar performance at production scales.

Fluidized Bed Steam Reforming is one of four technologies that have emerged as candidates for treating and immobilizing low-activity waste. One of those technologies will be selected for use to supplement the Waste and Immobilization Plant Low-Activity Waste Vitrification Plant in accordance with Department of Energy Orders, National Environmental Policy Act, and the TriParty Agreement over the next two to three years. 


\section{TABLE OF CONTENTS}

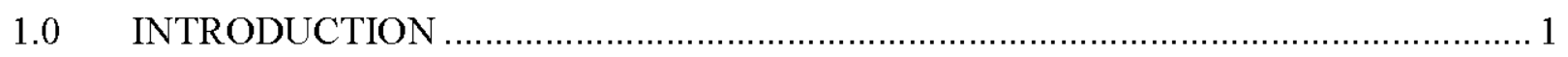

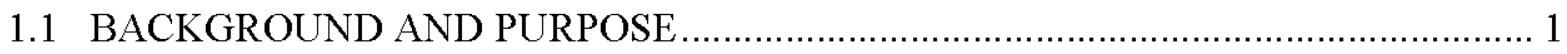

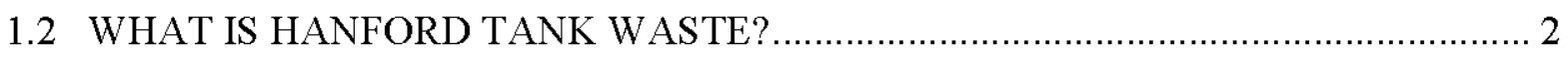

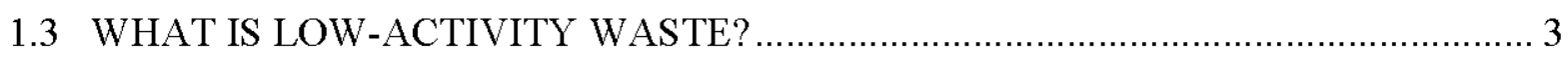

1.4 WHY MORE WTP LAW IMMOBILIZATION CAPACITY IS NECESSARY ............ 5

1.5 HOW WERE THE CANDIDATE LAW TECHNOLOGIES SELECTED? .................... 6

1.6 REGULATORY REQUIREMENTS FOR ON-SITE DISPOSAL OF LAW .................. 7

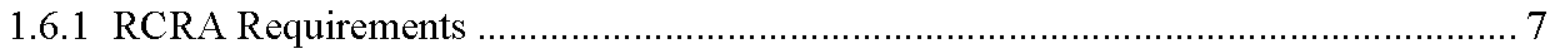

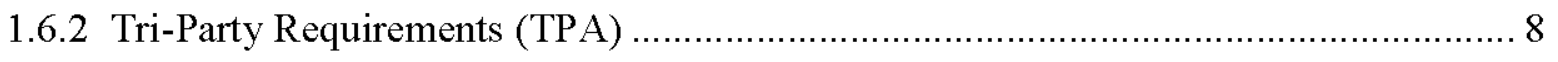

1.6.3 DOE Manual 435.1-1 Waste Incidental to Reprocessing (WIR) ............................... 8

1.6.4 DOE Manual 435.1-1 Disposal Authorization..................................................... 9

1.6.5 IDF Waste Acceptance Criteria Requirement....................................................... 9

1.6.6 IDF Permit Requirement............................................................................... 9

1.7 DETERMINING WASTE FORM PERFORMANCE ........................................... 10

1.7.1 Tests Used to Predict Long-Term Waste Form Performance ……............................ 10

1.7.2 Performance Objectives Used to Evaluate Performance Assessment Results............. 13

1.8 DESIRED ATTRIBUTES OF SELECTED TECHNOLOGIES …………….............. 16

2.0 INTRODUCTION TO FLUIDIZED BED STEAM REFORMING ............................ 17

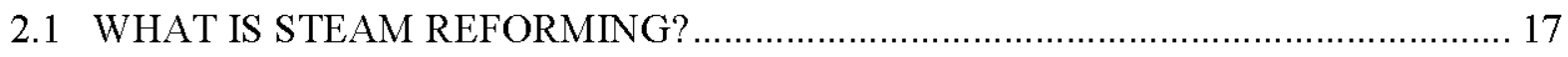

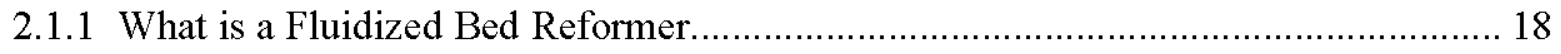

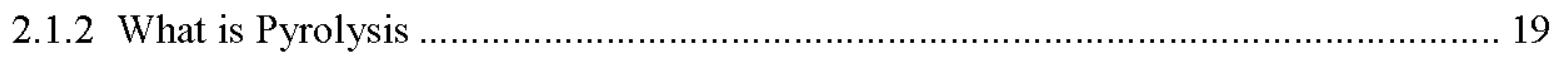

2.2 WHY FBSR IS BEING CONSIDERED AT HANFORD ………............................. 19

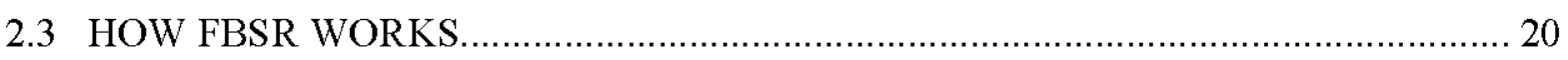

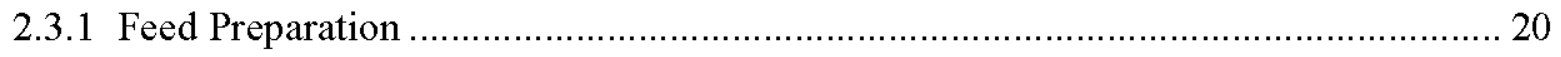

2.3.2 Immobilization Process Overview ……………………………………………... 21

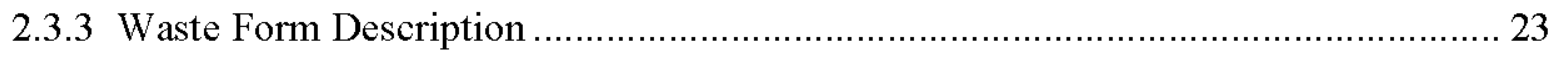

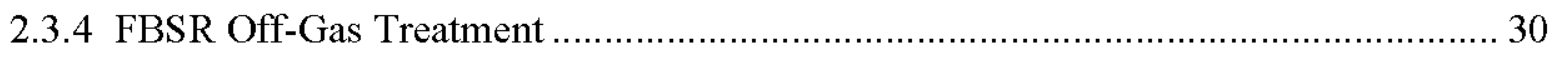

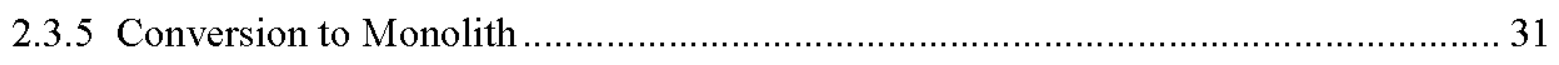

3.0 FBSR HISTORY RELEVANT TO RADIOACTIVE WASTE TREATMENT............. 34

3.1 PREVIOUS USES WITHIN THE DOE COMPLEX …………….............................. 34

3.2 PREVIOUS USES WITHIN COMMERCIAL INDUSTRY ………………............. 37 
4.0 CURRENT STATE OF KNOWLEDGE FOR USING FBSR AT HANFORD ............ 38

4.1 HOW FBSR MIGHT FIT INTO HANFORD FLOW SHEET .................................. 44

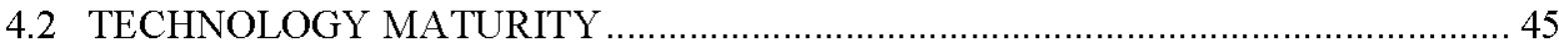

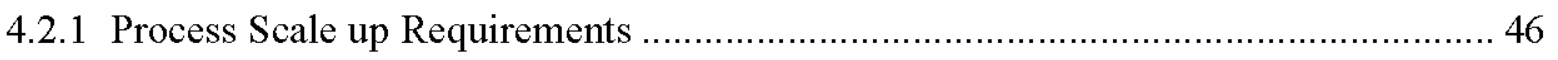

4.3 PROCESS SAFETY CONSIDERATIONS/CONCERNS .................................... 47

4.4 COST CONSIDERATIONS/CONCERNS ................................................... 48

4.5 WASTE FORM CHARACTERISTICS INCLUDING STRENGTHS, WEAKNESSES,

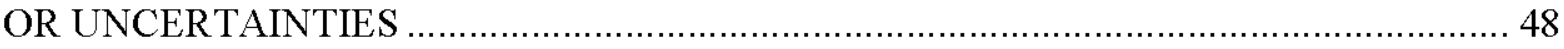

4.6 OFF-GAS TREATMENT REQUIREMENTS AND CONSTITUENTS RELEASED. 49

4.7 SECONDARY WASTE STREAMS ................................................................. 49

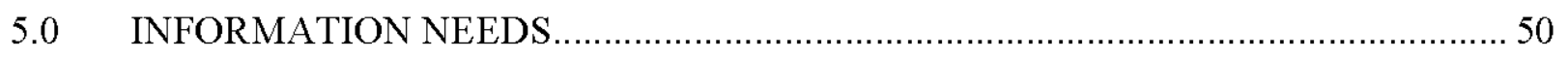

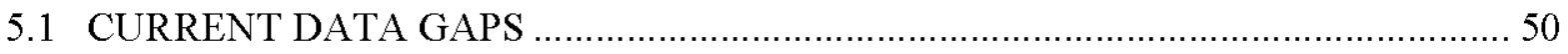

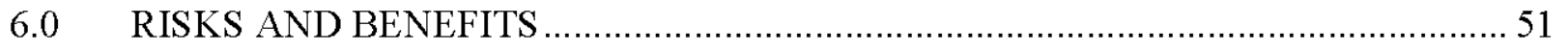

6.1 KEY TECHNICAL AND PROGRAMMATIC RISKS ASSOCIATED ..................... 51

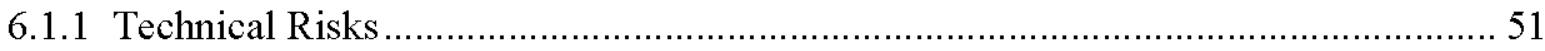

6.1.2 Regulatory/Programmatic Risks ........................................................... 51

6.2 BENEFITS AND PRINCIPAL ADVANTAGES …........................................... 52

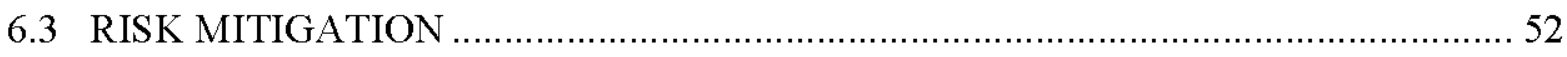

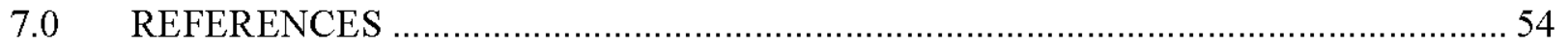

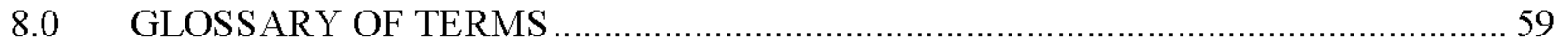

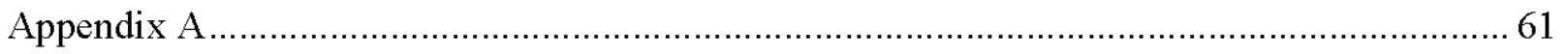


RPP-48903, Rev 0

\section{TABLE OF FIGURES}

Figure ES-1. Hanford Nominal Tank Waste Treatment \& Disposition Flowsheet ..................... iii Figure ES-2. Testing with Actual Hanford Tank Waste Provides Important Correlations

Necessary to Validate Results Obtained with Surrogate Wastes............................ V

Figure 2-1. Commercial Steam Reforming to Produce $\mathrm{H}_{2}$ Gas ............................................ 17

Figure 2-2. Simplified Depiction of the Fluidized Bed Concept ......................................... 18

Figure 2-3. Simplified Depiction of the FBSR Process to Produce a Mineral Waste Form........ 21

Figure 2-4. Simplified Depiction of FBSR Fines Entrainment, Separation in Product Separation

Filter, and Recombination with FBSR Product Stream ................................... 22

Figure 2-5.Photo of Typical Sample Material from FBSR including Granular, Fines, Clay, and Carbon 23

Figure 2-6. Molecular Arrangement in a Glass ............................................................... 26

Figure 2-7. Molecular Arrangement in a Crystal .............................................................. 27

Figure 2-8. Crystalline Structure of Nepheline .................................................................. 27

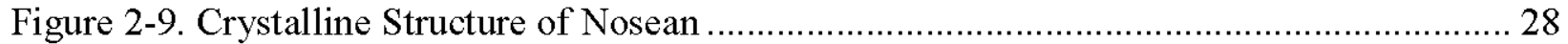

Figure 2-10. Comparison of FBSR Surface Area Estimation Techniques .............................. 30

Figure 2-11. Nominal FBSR Process and Off-Gas Treatment ............................................ 31

Figure 2-12. Depiction of Potential FBSR Product Conversion to Monolith........................... 32

Figure 2-13. Photo of Cylindrical GEO-7 Monoliths Formed to Test FBSR Product ............... 33

Figure 3-1. Depiction of Integrated Waste Treatment Unit at INL ....................................... 35

Figure 3-2. Commercial FBSR Resin/Sludge Treatment in Erwin, TN ............................... 37

Figure 4-1. Engineering and Bench-Scale FBSR Tests Conducted with Hanford Simulants ..... 38

Figure 4-2. Formation of Sodalite from Kaolin Clay during FBSR ..................................... 39

Figure 4-3. Depiction of Rhenium Bonded within the Crystal Lattice of a Single Sodalite Cell. 40 Figure 4-4. Testing with Actual Hanford Tank Waste Provides Important Correlations Necessary to Validate Results Obtained with Surrogate Waste Tests

Figure 4-5. Relationship Between Anions in Waste Feed and Mineral Phases Formed during

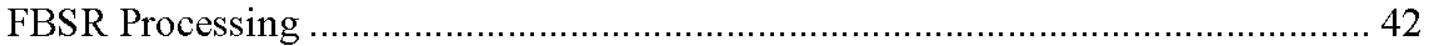

Figure 4-6. Integrated Summary Schedule for Technology Readiness Level and Critical Decision Process 45

Figure 4-7. Artist Depiction of a Dual Train FBSR Treatment Facility for Hanford LAW ........ 47

\section{TABLE OF TABLES}

Table 1-1. Principal Waste Form Test Protocols 11

Table 1-2. Key Performance Objectives for Performance Assessment.................................. 15

Table 4-1. Phases Identified by X-Ray Diffraction in FBSR Samples ..................................... 43

Table 4-2. FBSR Critical Technology Elements Technical Readiness Level ............................ 46 


\section{ACRONYMS}

Al

BDAT

BPP

CD

CRR

CERCLA

${ }^{137} \mathrm{Cs}$

DET

DMR

DOE

Ecology

EIS

EPA

ETF

FBSR

HEPA

HLW

${ }^{129} \mathrm{I}$

IDF

INL

IWTU

LAW

LLW

LDR

LFRG

LLW

MACT

MTGD

NAS

NEPA

NRC

OGC

ORNL

ORP

PA

PCT

PHOC

PNNL

PSF

PUF

PUREX

RCRA

REDOX

PNNL

PR

aluminum

Best Demonstrated Available Technology

Bismuth Phosphate Process

Critical Decision

Carbon Reduction Reformer

Comprehensive Environmental Response, Compensation, and Liability Act

cesium-137

Determination of Equivalent Treatment

Denitration Mineralization Reformer

U.S. Department of Energy

Washington State Department of Ecology

Environmental Impact Statement

U.S. Environmental Protection Agency

Effluent Treatment Facility

Fluidized Bed Steam Reforming

High-Efficiency Particulate Air

High-Level Radioactive Waste

iodine-129

Integrated Disposal Facility

Idaho National Laboratory

Integrated Waste Treatment Unit

Low-Activity Waste

Low-Level Waste

Land Disposal Restrictions

Low-Level Waste Federal Review Group

Low-Level Radioactive Waste

Maximum Achievable Control Technology

Metric Tons of Glass per Day

Sodium Aluminosilicate

National Environmental Policy Act

U.S. Nuclear Regulatory Commission

Off-Gas Cooler

Oak Ridge National Laboratory

DOE Office of River Protection

Performance Assessment

Product Consistency Test

Principal Organic Hazardous Constituents

Pacific Northwest National Laboratory

Product Separation Filter

Pressurized Unsaturated Flow

Plutonium Uranium Extraction

Resource Conservation and Recovery Act

Reduction-Oxidation

Pacific Northwest National Laboratory

Product Receiver 


$$
\text { RPP-48903, Rev } 0
$$

\begin{tabular}{|c|c|}
\hline ROD & Record of Decision \\
\hline RPP & River Protection Project \\
\hline SBW & Sodium-Bearing Waste \\
\hline SEM-EDS & Scanning Electron Microscopy with Energy-Dispersive Spectrometry \\
\hline SPFT & Single Pass Flow-Through \\
\hline SRNL & Savannah River National Laboratory \\
\hline SRS & Savannah River Site \\
\hline${ }^{90} \mathrm{Sr}$ & strontium-90 \\
\hline${ }^{99} \mathrm{Tc}$ & technetium-99 \\
\hline TCLP & Toxicity Characteristic Leaching Procedure \\
\hline TEM-EDS & Transmission Electron Microscopy with Energy-Dispersive Spectrometry \\
\hline THOR & THermal Organic $\underline{\text { Reduction }}$ \\
\hline TOC & Tank Operating Contractor \\
\hline TOE & Total Operating Efficiency \\
\hline TPA & Tri-Party Agreement \\
\hline TRL & Technology Readiness Level \\
\hline TTT & THOR Treatment Technologies, LLC \\
\hline TV & Treatability Variance \\
\hline $\begin{array}{l}\text { TWRS } \\
{ }^{238} \mathrm{U}\end{array}$ & $\begin{array}{l}\text { Tank Waste Remediation System } \\
\text { uranium- } 238\end{array}$ \\
\hline VHT & Vapor Hydration Test \\
\hline WAC & Waste Acceptance Criteria \\
\hline WIPP & Waste Isolation Pilot Plant \\
\hline WIR & Waste Incidental to Reprocessing \\
\hline WTP & Waste Treatment and Immobilization Plant \\
\hline \multirow[t]{2}{*}{$\mu \mathrm{XRD}$} & Micro X-ray Defraction \\
\hline & UNITS \\
\hline ci & curies \\
\hline $\mathrm{g}$ & grams \\
\hline gpm & gallons per minute \\
\hline $\mathrm{hr}$ & hour \\
\hline in & inch \\
\hline $\mathrm{kg}$ & kilogram \\
\hline 1 & liter \\
\hline lb & pound \\
\hline M & molar \\
\hline $\mathrm{m}^{2}$ & square meter \\
\hline MT & metric ton \\
\hline ppm & parts per million \\
\hline $\mathrm{R} / \mathrm{hr}$ & REM (roentgen equivalent man) per hour \\
\hline SCFM & standard cubic feet per minute \\
\hline
\end{tabular}




\subsection{INTRODUCTION}

\subsection{BACKGROUND AND PURPOSE}

The United States Department of Energy (DOE) is currently storing over 55 million gallons of wastes in underground storage tanks at it Hanford Site in Washington State. The DOE plans to separate the wastes into a High-Level Waste (HLW) stream and a Low-Activity Waste (LAW) stream. The HLW stream will be vitrified and ultimately disposed of off-site. Following treatment to remove key radionuclides to the maximum extent practical, the LAW stream will be immobilized for on-site disposal. Because tank wastes include both radioactive and hazardous waste constituents, the LAW will be treated, immobilized, and disposed of in a manner that meets performance objectives comparable to those in the U.S. Nuclear Regulatory Commission (NRC) regulations ${ }^{1}$ for the disposal of Low-Level Waste (LLW) ${ }^{2}$ and Resource Conservation and Recovery Act (RCRA) Land Disposal Restriction (LDR) requirements.

The DOE is currently building a LAW vitrification plant as part of the Waste Treatment and Immobilization Plant (WTP) that will convert a portion of the projected LAW waste stream into glass. The LAW Vitrification plant does not have the throughput capacity to vitrify all of the LAW. Accordingly, DOE is evaluating several immobilization techniques that could potentially be used to supplement the WTP LAW vitrification plant and convert the LAW into a solid waste form that safely meets applicable disposal requirements. Figure 1-1 depicts a nominal Hanford River Protection Project (RPP) flowsheet and indicates how supplemental LAW immobilization fits into the overall flowsheet regardless of the technology deployed.

The immobilization technologies currently under consideration include:

- Second $\left(2^{\text {nd }}\right)$ LAW vitrification;

- Cast Stone Technology (grout-based waste form tailored to Hanford LAW);

- Bulk Vitrification (in-container vitrification technology); and

- Fluidized Bed Steam Reforming (FBSR) (thermal process producing a mineral waste form).

The decision regarding which of the four technologies identified above will be ultimately deployed to supplement WTP LAW vitrification will be made in accordance with DOE Orders, the National Environmental Policy Act of 1968 (NEPA), and Hanford Federal Facility Agreement and Consent Order (Ecology et al. 1989) also known as the Tri-Party Agreement or TPA. It is not known as of this writing which technology will be selected. Discussions of these technologies are based on pre-conceptual design information. As such the level of design descriptions is general and specific cost information is not available.

\footnotetext{
${ }^{1} \mathrm{DOE}$ is not subject to NRC regulations for LAW waste treatment and disposition activities at Hanford; however, DOE does consult with the NRC on the classification of LAW as low-level waste and certain sections of NRC regulation $10 \mathrm{CFR}$ Part 61 are used in the classification processes.

${ }^{2}$ Note that while LLW and LAW are essentially the same relative to radioactivity, the term LAW only applies to DOE tank waste that has been pretreated to remove key radionuclides.
} 


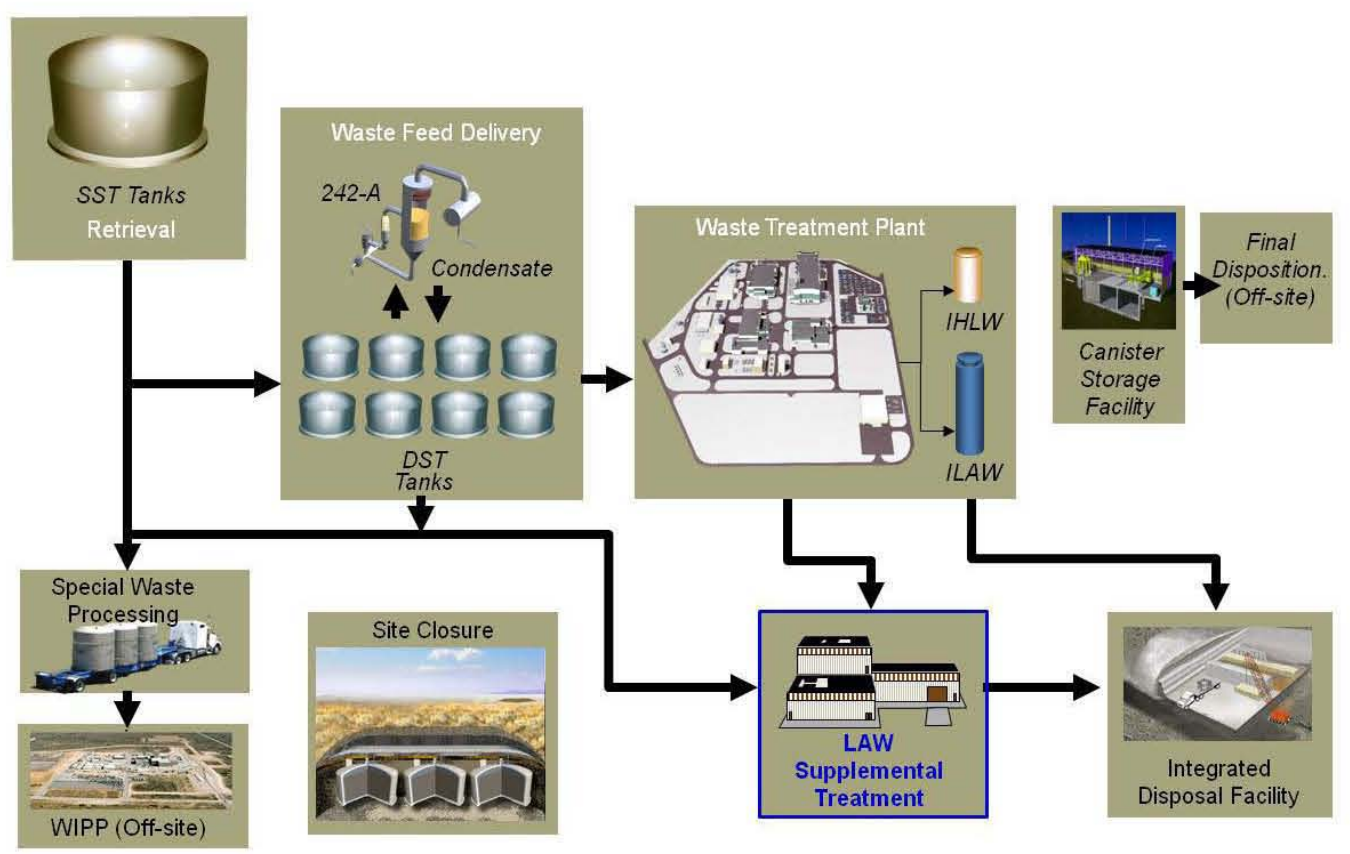

Figure 1-1. Hanford Nominal Tank Waste Treatment \& Disposition Flowsheet

\subsection{WHAT IS HANFORD TANK WASTE?}

The 177 Hanford underground storage tanks managed under the RPP contain over 55 million gallons of liquid (referred to as supernatant), saltcake, and sludge wastes, much of which was generated during the reprocessing of nuclear fuel to produce weapons grade plutonium $(\mathrm{Pu})$ for national defense. A variety of irradiated nuclear fuel reprocessing and chemical separations processes and campaigns were conducted at Hanford between 1945 and 1989, which resulted in highly complex chemical wastes in the Hanford tanks. Moreover, because Hanford started operations during World War II when stainless steel was in high demand, the Hanford tanks were constructed of carbon steel. The use of carbon steel required that the acidic reprocessing wastes be neutralized with sodium hydroxide $(\mathrm{NaOH})$ to prevent acid attack. This greatly added to the mass of chemicals stored in the tanks. In addition, the reprocessing technology used at Hanford for the first ten years was the Bismuth Phosphate Process (BPP). While that process produced very high purity $\mathrm{Pu}$ for the first nuclear weapons ever produced, the BPP created one hundred times more waste per ton of Pu recovered than the PUREX Process, which later became the standard for DOE uranium $(\mathrm{U})$ and $\mathrm{Pu}$ as well as for commercial spent nuclear fuel reprocessing.

The result is that the Hanford tank wastes are far more chemically complex and heterogeneous than tank wastes at other DOE production sites. The Hanford tank wastes also tend to have substantially lower average radionuclide concentrations than other DOE tank wastes because of the inefficient recovery processes initially used (BPP), and the more than one hundred million curies of radionuclides [particularly cesium-137 $\left({ }^{137} \mathrm{Cs}\right)$ and strontium-90 $\left.\left({ }^{90} \mathrm{Sr}\right)\right]$ that were removed from the Hanford tanks forty years ago.

It is generally understood that the highly radioactive materials resulting from the reprocessing of spent nuclear fuel are HLW (NWPA 1983, Nuclear Waste Policy Act of 1983, Public Law 97425; 96 Stat. 2201). Given the high cost and limited availability of potentially suitable deep 
geologic disposal sites for HLW, DOE recognizes that the high chemical content of the Hanford tank waste was unsuitable for total immobilization as vitrified HLW. Figure 1-2, which was derived from data in the Hanford Tank Waste Information Network System (TWINS) database, illustrates the relationships between the mass of radionuclides and the mass of chemicals that make up the Hanford tank wastes.

The pretreatment processes that will be carried out in the WTP pretreatment plant accomplish two key activities. First they separate the chemical wastes from the radioactive materials to the maximum extent practical to minimize the mass of wastes that will require vitrification as HLW. Second, by removing key radionuclides from the chemical waste fraction to the maximum extent technically and economically practical, the pretreatment processes should satisfy the first Waste Incidental to Reprocessing (WIR) criterion in DOE Manual 435.1-1,

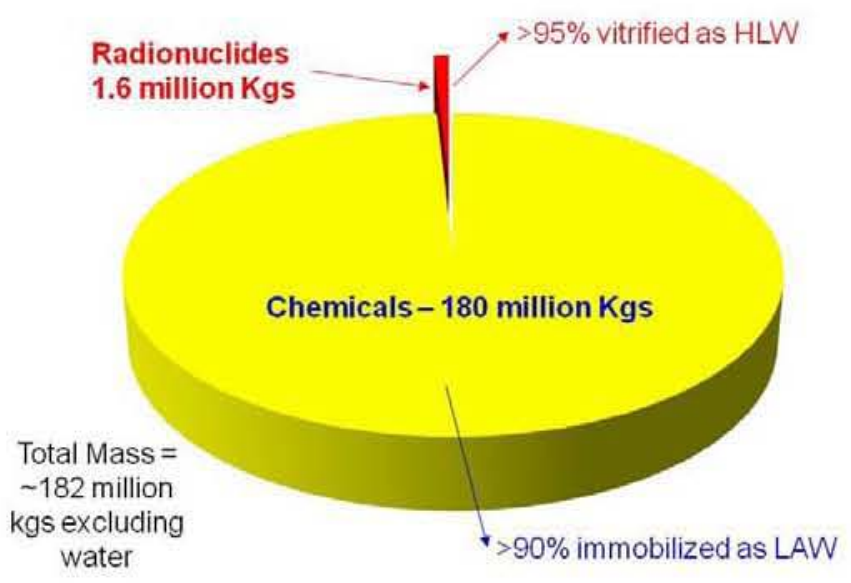

Figure 1-2. Radionuclides Make Up a Small Fraction of Hanford Tank Waste

Radioactive Waste Management. The second factor is a critical element to classifying the LAW as non-HLW suitable for disposal on-site at Hanford. In addition to the chemicals in the tanks, substantial quantities of process sodium $(\mathrm{Na})$ will be added during the pretreatment of the tank wastes. The Hanford tanks contain approximately 48,000 metric tons (MT) of Na, essentially all of which will require immobilization as LAW. Additional process $\mathrm{Na}$ will be added during the waste pretreatment in the WTP.

The largest contributor to pretreatment $\mathrm{Na}$ additions will result from $\mathrm{NaOH}$ added to remove $\mathrm{Al}$ from HLW sludge waste during hot sludge leaching and the additional $\mathrm{NaOH}$ added to keep the aluminum (Al) in solution as the leachate is cooled from $80^{\circ}-90^{\circ}$ Celsius (leach temperature) to $25^{\circ}-45^{\circ}$ Celsius for processing through the cesium (Cs) ion exchange system. Because the LAW storage and treatment systems in the WTP pretreatment plant are not designed to handle solids (solids are separated and sent to the HLW storage and treatment systems), it is important that solids do not precipitate in those systems. For purposes of this report it is estimated that the total mass of $\mathrm{Na}$ that will require immobilization will be in the range of 65,000 to $70,000 \mathrm{MT}$.

\subsection{WHAT IS LOW-ACTIVITY WASTE?}

Low activity waste is the fraction of the tank wastes that is mostly chemicals and from which key radionuclides have been removed to the maximum extent technically and economically practical to render the waste not highly radioactive. The DOE will use a formal process to establish that the LAW waste produced through its planned pretreatment and immobilization processes is not 


\section{RPP-48903, Rev 0}

HLW and is suitable for disposal on-site. The criteria used to make a determination ${ }^{3}$ that the LAW is not HLW were developed in concert with the NRC (Bernero 1993) and the NRC will consult with DOE on its analyses showing that those criteria are met. The criteria are contained in DOE Manual 435.1-1, "Waste Incidental to Reprocessing (WIR) Requirements". The process by which the waste determination is made is called the WIR evaluation process. That process requires that $\mathrm{DOE}$ demonstrate that:

1. Waste is processed to remove key radionuclides ${ }^{4}$ to the maximum extent technically and economically practical,

2. If the treated and immobilized waste is disposed of by land disposal, that performance objectives comparable to those set forth in 10 CFR 61, Subpart C will be met, and

3. Waste is converted into a solid material with radionuclide concentrations that do not exceed 10 CFR 61.55 Class C concentration limits.

The resulting waste would be radioactively equivalent to LLW (i.e., no longer highly radioactive) and proven to be safe for disposal on-site. Given the derivation of the waste from tank wastes, DOE applies the term LAW to avoid confusion with wastes that are LLW at the point of generation. Because the Hanford tank wastes are regulated under the RCRA, LAW wastes are mixed LLW.

A two-step treatment approach removes the key radionuclides to the maximum extent technically and economically practical. The first step conducts solid and liquid separations on the liquid waste (supernatant) from the tanks to remove insoluble radionuclides such as transuranic isotopes and ${ }^{90} \mathrm{Sr}$. The second step performs Cs ion exchange on those wastes to remove ${ }^{137} \mathrm{Cs}$. The Hanford WTP implements this key radionuclide removal approach in the pretreatment plant. The plant produces the LAW liquid feed that will be converted to glass in the LAW melters. Figure 1-3 depicts the basic pretreatment concept to produce Hanford LAW feed from tank waste.

\footnotetext{
${ }^{3}$ The same criteria and process will also be applied to other tank waste related waste streams such as residuals remaining following the retrieval of wastes from tanks in accordance with TPA retrieval requirements.

${ }^{4}$ Key radionuclides generally refers to those radionuclides that if not removed would result in the most significant impacts to human health.
} 


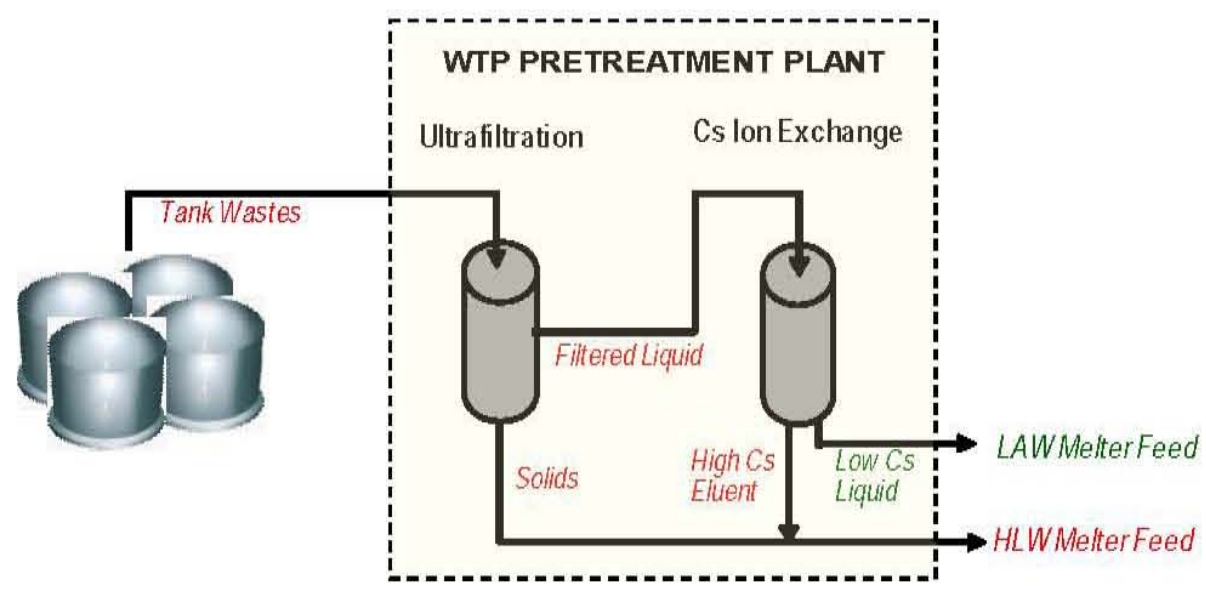

Figure 1-3. Depiction of Basic Pretreatment Processes to Remove Key Radionuclides from Hanford Tank Waste and Produce LAW Feed for Immobilization

While Figure 1-3 illustrates the WTP pretreatment processes currently under construction, DOE is also considering supplemental pretreatment approaches that would provide filtration and ion exchange pretreatment of LAW feed in the tank farms. This latter approach could potentially decrease the treatment mission duration by enabling the WTP pretreatment plant to primarily focus on the sludge pretreatment processes.

\subsection{WHY MORE WTP LAW IMMOBILIZATION CAPACITY IS NECESSARY}

The Hanford WTP Project was established in the 1990's. It was under a privatization concept wherein a private contractor would design, build, and operate the WTP using its own funding sources, i.e., no upfront federal funding. The contractor was to be paid on a unit basis as waste was successfully treated and immobilized.

Given project uncertainties and the high cost of building treatment facilities, a phased implementation approach was planned. The first phase would include a pretreatment facility, a HLW vitrification facility, and a LAW vitrification facility. The initial WTP would treat at least $10 \%$ of the tank waste mass containing at least $25 \%$ of the tank waste radioactivity during Phase I. Based on lessons learned during Phase I, the WTP would be upgraded to complete treatment and immobilization of the remaining tank wastes during Phase II.

The pretreatment plant was to be designed to process all of the tank waste over both mission phases, but would operate at a relatively low throughput capacity during Phase I. The HLW vitrification plant was designed to accommodate two melters, each processing 3 metric tons of glass per day (MTGD), however, only one 1.5 MTGD melter was to be initially installed and used for Phase I operations. The LAW vitrification plant was initially planned for three LAW melters, but the design was finalized for two LAW melters having a total net throughput capacity of net 30 MTGD, which was sufficient to handle all LAW generated during Phase I. The LAW immobilization throughput would need to be increased for Phase II to several times the throughput that could be provided by the first LAW plant. While economies of scale made it practical to design the Pretreatment and HLW vitrification facilities to accommodate the higher throughput required for Phase II, the same was not true for the LAW vitrification plant for two reasons. 


\section{RPP-48903, Rev 0}

The first was uncertainty regarding how much LAW immobilization capacity would actually be required to complete the overall treatment mission. One of the principal objectives of the WTP is to transfer as much non-radioactive waste mass as reasonable from the HLW fraction to the LAW fraction in order to minimize the amount of geologic repository space and disposal cost required to accommodate the HLW. DOE was conducting studies to determine how much $\mathrm{Al}$ and other non-radioactive wastes could be leached from the HLW sludge from the tanks, as well as to determine how much non-waste, sodium hydroxide $(\mathrm{NaOH})$ would need to be added during pretreatment to reach its objectives. Whatever waste was leached from the HLW sludge and whatever Na needed to be added to the process to effect that removal was to be immobilized as LAW. Consequently, DOE did not know how large the LAW immobilization capacity would be during Phase II.

A second reason was uncertainty regarding whether LAW vitrification would prove to be the best immobilization solution for all of the LAW that would be generated. DOE and international entities in the United Kingdom and France had experience with the vitrification of HLW. Vitrification of LAW, however, was unique to Hanford. The Tank Waste Remediation System (TWRS) Environmental Impact Statement (EIS) Record of Decision (ROD) (62 FR 8693, Record of Decision for the Tank Waste Remediation System) left open the possibility other remediation approaches could result as information emerged during the conduct of the mission.

"The Phased Implementation alternative was selected because it provides a balance among short-and long-term environmental impacts, meets all regulatory requirements, addresses the technical uncertainties associated with remediation, and provides the flexibility necessary to accommodate future changes in the remediation plans in response to new information and technology development." [TWRS EIS ROD, DOE 1997]

\subsection{HOW WERE THE CANDIDATE LAW TECHNOLOGIES SELECTED?}

In 2002 and 2003 DOE initiated a series of meetings with Washington State Department of Ecology (Ecology) and the U.S. Environmental Protection Agency (EPA) that were focused on determining whether an approach other than building a Second WTP LAW Vitrification Plant would best fill out the RPP flowsheet and, if so, what technologies should be considered ${ }^{5}$. Over the course of a year, a joint work group with representatives from each of those agencies and the Hanford Tank Farm Contractor reviewed several dozen potential technical approaches; four of which were evaluated in detail as the primary contenders for completing the LAW immobilization mission. Those four are the same as were listed earlier in the Introduction of this report, Second LAW Vitrification Plant, Bulk Vitrification, Cast Stone, and FBSR.

A procurement process was initiated to obtain design, cost, and waste form data for the latter three technologies. This was not considered necessary for the Second LAW Vitrification Plant given the significant DOE investment in that technology and information available from the WTP Project.

\footnotetext{
${ }^{5}$ The meetings were held as a subgroup of the Cleanup, Constraints, and Challenges Team (C3T), an informal forum where ideas and concepts could be discussed openly between DOE, EPA, and Ecology. Ideas were developed and evaluated to determine whether they could accelerate cleanup; reduce costs; or protect workers, the public, and the environment.
} 


$$
\text { RPP-48903, Rev } 0
$$

On the basis of its meetings with the Ecology and EPA, DOE decided to further evaluate Bulk Vitrification at Hanford based primarily on a substantial cost advantage it appeared to have over a Second LAW Vitrification Plant and FBSR. DOE further decided that Idaho National Laboratory (INL) would conduct FBSR studies considering both INL sodium-bearing waste (SBW) and Hanford LAW. The Savannah River Site (SRS) was already substantially invested in Saltstone, the SRS equivalent to Cast Stone, which SRS planned to use to immobilize its counterpart to Hanford LAW.

\subsection{REGULATORY REQUIREMENTS FOR ON-SITE DISPOSAL OF LAW}

There are six sets of regulatory requirements that must be met to dispose of immobilized LAW on-site at Hanford.

- RCRA Requirements, ( Resource Conservation and Recovery Act of 1976)

- TPA Requirements (DOE, 1989, Hanford Federal Facility Agreement and Consent Order - Tri-Party Agreement, (TPA),

- DOE Manual 435.1-1 Waste Incidental to Reprocessing (WIR) Requirements,

- DOE Manual 435.1-1 Disposal Authorization Requirements,

- Integrated Disposal Facility (IDF) IDF 2004, Integrated Disposal Facility Waste Acceptance Criteria, and

- IDF Permit Requirements. (IDF 2004 CEES-0134, Rev. B, Integrated Disposal Facility Waste Acceptance Criteria.)

Each is briefly discussed below.

\subsubsection{RCRA Requirements}

All Hanford tank waste is regulated under RCRA because of the hazardous constituents in the tank wastes. The hazardous (dangerous waste) constituents are also regulated under the Washington State Hazardous Waste Management Act and respective implementing regulations. The tank wastes carry RCRA codes D002 (corrosive), D004 (toxicity arsenic (As)), D005 (toxicity barium (Ba)), D006 (toxicity cadmium (Cd)), D007 (toxicity chromium (Cr)), D008 (toxicity $\mathrm{Pb}$ ), D009 (toxicity mercury (Hg)), D010 (toxicity selenium (Se)), and D011 (toxicity silver (Ag)) for which the RCRA best demonstrated available technology (BDAT) is High Level Vitrification (HLVIT). In order to deploy a non HLW vitrification technology to treat the tank wastes DOE would need to submit a request for a Determination of Equivalent Treatment (DET) to the EPA for the alternative technology. The EPA would need to approve the DET before DOE could deploy the technology. The DET formally establishes the adequacy of the nonvitrification technology to treat the LAW and establish that the final waste product will meet RCRA LDR.

In addition, since DOE plans to base the contents of the immobilized waste on its analysis of what is in the waste feed rather than sample the contents of every immobilized waste package, DOE must also request Ecology to approve a Treatability Variance (TV) to enable that approach. This would be required regardless of the immobilization technology deployed.

DOE must also obtain a RCRA permit to build and operate any facility to treat and immobilize the LAW regardless of the technology deployed. 


\section{RPP-48903, Rev 0}

\subsubsection{Tri-Party Requirements (TPA)}

The TPA (http://www.hanford.gov/?page=82 ) was signed in 1989 by Ecology, EPA and DOE with the purpose of coordinating the Comprehensive Environmental Response, Compensation, and Liability Act (CERCLA) and RCRA cleanup authorities at Hanford. The TPA also identifies specific cleanup milestones to be met; the process for changing, removing, or adding milestones; the conditions under which penalties may be issued; and the requirements for public involvement relating to Hanford cleanup actions. Major changes to the TPA require approval of all three agencies and are only made after a public participation process has been followed.

Appendix D to the TPA, Work Schedule and Designation of Lead Regulatory Authority, establishes key milestones for the processing and immobilization of the HLW and LAW from the Hanford tanks (M-062 milestone series). These include (paraphrased):

M-062-00 Complete all treatment and immobilization of tank wastes by December 31, 2047.

M-062-30 Complete negotiations establishing milestones for implementing near-term (2011 2016) actions related to LAW treatment and immobilization (October 2011).

M-062-40 Multipart milestone that includes requirement for DOE to submit a one-time Hanford Tank Waste Supplemental Treatment Technologies Report if a technology other than a $2^{\text {nd }}$ LAW vitrification facility is proposed.

M-062-45 Multipart milestone that includes requirement for a one-time supplemental LAW treatment selection consistent with M-062-00 including implementing supplemental treatment milestones (April 30, 2015).

M-062-49 Submit a report to Ecology with data certified to be accurate that demonstrates that the WTP is designed to accomplish at least the pretreatment of $100 \%$ of retrievable waste, vitrify $100 \%$ of HLW, and WTP LAW with supplemental treatment can immobilize 100\% of LAW (October 31, 2011).

\subsubsection{DOE Manual 435.1-1 Waste Incidental to Reprocessing (WIR)}

Most of the waste in the Hanford tanks either originated during spent nuclear fuel reprocessing or has been subsequently comingled with reprocessing wastes. In order to manage and dispose of tank waste as other than HLW, DOE must determine the waste to not be HLW using either the citation or evaluation WIR process set forth in DOE Manual 435.1-1. The citation process is primarily applied to wastes that can be readily determined to not be HLW based on inspection, e.g., contaminated tools and clothing. The responsible DOE field element manager makes the process determinations.

Evaluation process WIR determinations are more complex. With evaluation process WIRs, treatment and analyses are required to render the waste not highly radioactive and then demonstrate that it is suitable for disposal in a LLW disposal site. Treatment (e.g., ultra or micro filtration and $\mathrm{Cs}$ ion exchange) is required to remove key radionuclides (typically actinides, ${ }^{90} \mathrm{Sr}$, and ${ }^{137} \mathrm{Cs}$ ) to the maximum extent technically and economically practical. An engineering trade study is required to demonstrate that the degree of radionuclide removal will meet that objective. 


\section{RPP-48903, Rev 0}

A performance assessment and other analyses are required to demonstrate that performance objectives comparable to those in 10 CFR Part 61, Subpart C will be met if the waste is disposed of by land disposal, e.g., in the Hanford IDF. Additional analyses are required to demonstrate that the immobilized waste will have radionuclide concentrations within those set forth in 10 CFR 61.55, Class C concentration limits.

Once the WIR analyses and supporting documentation are approved by DOE HQ, the draft WIR is published in the Federal Register and public comments are elicited. DOE also requests NRC staff consultation on the draft WIR and supporting documentation. This typically takes nine months or longer and involves NRC requests for additional information, DOE responses to those requests, and a NRC Technical Evaluation Report. Once the NRC and public input are integrated into the WIR as appropriate, the formal evaluation process WIR determination is made by the responsible DOE secretarial officer or designee.

\subsubsection{DOE Manual 435.1-1 Disposal Authorization}

In order for a waste to be disposed of in a DOE disposal facility such as the IDF, a formal disposal authorization must be in place that authorizes disposal. The disposal authorization is issued by an EM Deputy Assistant Secretary and is largely based on a recommendation from the Low-Level Waste Federal Review Group (LFRG) that the disposal facility is adequately protective of human health and the environment based on a Performance Assessment (PA) developed for that facility and contributing impacts from near-by facilities.

\subsubsection{IDF Waste Acceptance Criter ia Requirement}

Waste acceptance criteria will be established for the IDF that places restrictions or requirements on wastes received at that facility for disposal in order to ensure that those wastes are properly characterized and documented by the waste generator relative to their origin, constituents, inventory, and characteristics or properties of the waste forms. The waste acceptance criteria is in part derived to be consistent with the waste types/inventories evaluated in the PA for the facility and in part based on engineering considerations such as compressive strength to protect against post-disposal surface subsidence.

At present, the IDF waste acceptance criteria exists in draft form (IDF 2004, CEES-0134, Rev. B, Integrated Disposal Facility Waste Acceptance Criteria). The waste acceptance criteria will need to be finalized prior to waste acceptance for disposal in the IDF.

\subsubsection{IDF Permit Requirement}

Because the ILAW and related secondary waste to be disposed of in the IDF are derived from the Hanford tank waste, those wastes are regulated under RCRA and must meet RCRA LDR.

Moreover, the IDF disposal cells that receive those wastes are subject to a RCRA permit issued by Ecology. The current IDF RCRA permit only covers ILAW glass from the WTP and up to 50 boxes of vitrified waste from Bulk Vitrification. The permit will need to be updated in order to receive secondary wastes from the tank farms and WTP as well as ILAW from other than a Second WTP LAW Vitrification Facility. The permit update will in part be based on the results set forth in the IDF PA. 
RPP-48903, Rev 0

\subsection{DETERMINING W ASTE FORM PERFORMANCE}

\subsubsection{Tests Used to Predict Long-Term Waste Form Performance}

A variety of tests are used to determine the long-term performance properties of candidate waste forms (waste form durability). Information derived from those tests is used to provide waste form performance input to the IDF PA analyses. The types of tests used depend, in part, upon the type of waste form. While ideally a waste form would hold radioactive and hazardous constituents permanently, that just is not practical to achieve. Rather, the purpose of a waste form is to retard the release of radioactive and hazardous constituents such that releases are at very low rates and extend over very long periods, such that impacts to human health and the environment are within levels allowed by environmental laws and regulations. Because the times over which releases can occur are typically measured in thousands, tens of thousands, or even millions of years for $100 \%$ release, the tests and analytical techniques used to measure waste form performance must rely on relatively short-term periods of measurements (days, months, or years) to make very long-term predictions.

Accordingly, scientists have devised ways to approximate the long-term corrosion of waste forms over the shorter time frames during which tests can be reasonably conducted using tests at higher temperatures and higher $\mathrm{pH}$ conditions, both of which accelerate the rate of attack well beyond what would occur in the Hanford vadose zone environment. Some waste forms, such as Cast Stone, release contaminants when water or contaminants move through the waste form by diffusion through the small pores within the waste form. Other waste forms such as glass and minerals suffer surface corrosion, are protected for some period of time by the corrosion product buildup on their surfaces, and then suffer corrosion again when the corrosion products are ultimately flushed or dissolved away. Determining the rates of releases for such waste forms requires batteries of complex tests and complex kinetic rate equations.

For glass and for mineral waste forms such as produced by the FBSR process, the tests are essentially the same due to similarities in the means by which those two waste forms eventually release contaminants to the vadose zone groundwater. In both cases kinetic rate equations are used to calculate the projected release rates, which can span millions of years. Cast stone uses some different test protocols that are focused on diffusion through the waste form over periods of thousands or tens of thousands of years. The applicability of the tests to various waste forms is shown in Table 1-1. A brief discussion of each test protocol ${ }^{6}$ is provided below.

\footnotetext{
${ }^{6}$ The Vapor Hydration Test (VHT), is not discussed because it was specifically developed for glass, has not yet been adequately demonstrated to the scientific community to provide information that correlates well to long-term performance (WSRC-STI-2008-00268), and is not well suited for surrogate testing.
} 
RPP-48903, Rev 0

\begin{tabular}{|l|l|l|l|l|}
\hline \multicolumn{7}{|c|}{ Table 1-1. Principal Waste Form Test Protocols } \\
\hline Test Protocol & $\begin{array}{l}\text { WTP LAW } \\
\text { Glass }\end{array}$ & $\begin{array}{l}\text { Bulk } \\
\text { Vitrification }\end{array}$ & $\begin{array}{l}\text { FBSR } \\
\text { Mineral }\end{array}$ & $\begin{array}{l}\text { Cast } \\
\text { Stone }\end{array}$ \\
\hline Toxicity Characteristic Leaching Procedure (TCLP) & $\checkmark$ & $\checkmark$ & $\checkmark$ & $\checkmark$ \\
\hline Product Consistency Test (PCT or ASTM C1285) & $\checkmark$ & $\checkmark$ & $\checkmark$ & \\
\hline Single Pass Flowthrough Test (SPFT or ASTM C1662) & $\checkmark$ & $\checkmark$ & $\checkmark$ & \\
\hline Pressurized Unsaturated Flow (PUF) test & $\checkmark$ & $\checkmark$ & $\checkmark$ & \\
\hline ASTM D6527, Hydraulic Conductivity in Porous Media & & & & $\checkmark$ \\
\hline ASTM/ANS 16.1, Leachability of Solidified LLW & & & & $\checkmark$ \\
\hline $\begin{array}{l}\text { ASTM C39/C 39M, Compressive Strength of Cylindrical } \\
\text { Concrete Specimens }\end{array}$ & & & & $\checkmark$ \\
\hline
\end{tabular}

TCLP-The EPA Test Method 1311, Toxicity Characteristic Leaching Procedure (TCLP) is designed to determine the mobility of both organic and inorganic analytes present in liquid, solid, and multiphasic wastes. This usually determines if a waste may meet the definition of EPA toxicity, that is, carrying a hazardous waste code under RCRA (40 CFR Part 261) of D004 through D052. The TCLP analysis simulates landfill conditions and determines which of the contaminants identified by the EPA are present in the leachate and the concentrations of such contaminants. For Hanford tank wastes, TCLP analysis will be used to determine whether the treated immobilized waste will meet RCRA LDR (42 USC 6901, Resource Conservation and Recovery Act, 40 CFR 268, and WAC 173-303, Washington State Dangerous Waste Regulations to be suitable for on-site disposal.

$P C T$ - The Product Consistency Test (PCT) was developed between 1987 and 1994 when it became an ASTM standard for HLW borosilicate glass (Jantzen 1994). In 1997 and 2002 the scope was broadened to include hazardous waste glasses, mixed waste glasses, and glass ceramics. Based on extensive testing of glasses and glass-ceramics, including a seven-laboratory round robin, and confirmatory testing with radioactive samples, the PCT has been shown to be reproducible to distinguish between waste forms of different durability and homogeneity, to yield reliable results, and to be suitable for radioactive samples testing. Additional PCT testing of ceramic waste forms has occurred since 2002 and application of this test to ceramic waste forms is currently being considered by ASTM (WSRC-STI-2008-00268, "Mineralization of Radioactive Wastes by Fluidized Bed Steam Reforming (FBSR); Comparisons to Vitreous Waste Forms and Pertinent Durability Testing").

The PCT uses a granular waste form product typically between $>74 \mu \mathrm{m}$ and $<149 \mu \mathrm{m}$ at elevated temperature $\left(90^{\circ} \mathrm{C}\right)$ in de-ionized water at a solid-to-water ratio of $10 \mathrm{~g} / \mathrm{mL}$. The PCT testing will be conducted using water solutions developed to represent burial conditions in the IDF,

\footnotetext{
${ }^{7}$ Applied to waste form once in monolithic form.
} 


\section{RPP-48903, Rev 0}

including natural vadose zone water chemistry and vadose zone water chemistry altered by groundwater attack on waste disposed of in the IDF. Ideally, PCT tests should be conducted over extended times (months to years) to better represent in situ weathering processes and to enable modeling of the weathered state of the waste form. The long-term PCT tests will be conducted consistent with ASTM C1285 - 02, 2008, "Standard Test Methods for Determining Chemical Durability of Nuclear, Hazardous, and Mixed Waste Glasses and Multiphase Glass Ceramics: The Product Consistency Test (PCT)".

SPFT - The SPFT test (ASTM C1662-10, Standard Practice for Measurement of the Glass Dissolution Rate Using the Single-Pass Flow-Through Test Method) is designed to measure reaction rates under tightly controlled, dilute solution conditions. Dissolution of silicate glasses or minerals in an aqueous solution is a dissociation-association process in which two or more soluble species are released into or removed from solution. It is subject to the common ion effect, which occurs when a solution already contains the same ions that would be released when a solid dissolves (or precipitates). The presence of common ions released from the glass or from other sources reduces the net rate of release relative to the rate in pure water. Hence, the idea of the SPFT test is to remove the elements released into solution from waste form dissolution by continuously introducing fresh water into the system. Run properly, the SPFT test provides a direct measure of the so-called "forward reaction rate." The forward reaction rate is the maximum rate at which a silicate glass or mineral can dissolve at a given temperature and $\mathrm{pH}$. Once the forward rate is known, it is straight forward to calculate the absolute upper bound on the release rate of any glass component, including a radionuclide such technetium- $99\left({ }^{99} \mathrm{Tc}\right)$.

The SPFT test as a LAW product acceptance test is attractive for several reasons. First, the test provides a direct measure of the maximum possible corrosion rate of a glass or mineral that can be used in performance assessment analyses. Second, the test eliminates ambiguity that is unavoidable in interpreting the results from a closed-system test such as the PCT, where the solution $\mathrm{pH}$ and concentration of waste form components change as a function of time. The changing $\mathrm{pH}$ is particularly problematic because SPFT tests show that the forward reaction rate increases by approximately a factor of 3 for every unit increase in $\mathrm{pH}$ over the $\mathrm{pH}$ range from 7 to 12 . Also, secondary phases can form in the PCT, which means that the solution concentration of some components may not give an accurate measure of the waste form corrosion rate. Finally, because the PCT is a closed-system test, the results, particularly at early times and temperatures $<40^{\circ} \mathrm{C}$, are subject to phenomena such as ion-exchange, dissolution of fines, and reaction of highly strained fracture surfaces that are not true measures of the long-term, waste form dissolution rate.

PUF - PUF tests (McGrail, Accelerated Testing of Waste Forms Using a Novel Pressurized Unsaturated Flow (PUF) Method) are important because they are conducted under hydraulically unsaturated conditions, which are the hydraulic conditions that exist in the vadose zone where the wastes will be ultimately disposed. PUF tests allow the corroding waste form to achieve its final reaction state in the most representative geochemical environment. Accordingly, PUF tests can provide insights into:

- Alteration phases that will form over time when the wastes are contacted by unsaturated groundwater,

- Time-phased changes in leachate (groundwater) chemistry resulting from waste form-groundwater interactions, and 


\section{RPP-48903, Rev 0}

- Waste form water reactions that occur under hydraulically unsaturated conditions similar to those expected in the Hanford disposal-system environment.

The PUF tests are conducted at elevated temperatures that accelerate the rate of attack on the waste form to enable predictions of long-term releases using tests conducted over months or years. Correlations will be developed between PUF test results and those obtained from the simpler (and less expensive) PCT tests and SPFT tests. PUF tests require the use of expensive equipment and protocols that limit the number of tests that can be performed with available equipment.

\section{American Society for Testing Materials (ASTM) tests:}

ASTM D6527 - ASTM test method D6527, Test Method for Determining Unsaturated and Saturated Hydraulic Conductivity in Porous Media by Steady-State Centrifugation, is useful for measuring the hydraulic conductivity of grout-based waste forms. It is useful in measuring hydraulic conductivity in unsaturated disposal sites such as exists in the Hanford vadose zone.

ASTM C39/C39M - ASTM C39/C39M, Standard Test Method for Compressive Strength of Cylindrical Concrete Specimens, is a test used to determine the compressive strength of cylindrical concrete specimens such as molded cylinders and drilled cores with densities in excess of $50 \mathrm{lb} / \mathrm{ft}^{3}\left[800 \mathrm{~kg} / \mathrm{m}^{3}\right]$. The test protocols are also used for the FBSR monolithic waste form.

American National Standards Institute (ANSI)/American National Standards (ANS) test:

ANSI/ANS 16.1 - ANSI/ANS 16.1, Measurement of the Leachability of Solidified Low-Level Radioactive Waste, leaching procedure is used to determine the concentration and to calculate the leach rate for $\mathrm{Tc}, \mathrm{U}$, I, nitrate, nitrite, $\mathrm{Cr}$, and $\mathrm{Cs}$. This standard provides a uniform procedure to measure and index the release of radionuclides from waste forms as a result of leaching in demineralized water for five days (seven data points). The results can be interpreted to apply to specific environmental situations through correlative studies of actual disposal site conditions.

\subsubsection{Performance Objectives Used to Evaluate Performance Assessment Results}

The ILAW waste form selected for use must be evaluated in the IDF PA and be shown to be protective of human health and the environment. The PA will evaluate the first 10,000 years following IDF closure and will also identify the time and magnitude of maximum doses if those peaks occur after 10,000 years. From a practical point of view, however, predictions of waste form performance and the fate and transport of long-lived radionuclides (such as ${ }^{99} \mathrm{Tc},{ }^{129} \mathrm{I}$, and ${ }^{238} \mathrm{U}$ ) over tens of thousands of years are subject to a number of uncertainties. These include those associated with using accelerated testing techniques to predict long-term waste form performance, as well as those associated with uncertainties regarding the chain of events assumed to occur in performance assessments. The latter are illustrated in Figure 1-4, which is adapted from RPP-15834, Revision 0, Integrated Disposal Facility Risk Assessment. As such, the performance assessment does not make a prediction of what will occur, but rather, tests the durability and robustness of the waste form and waste disposal system to perform acceptably given the variety of conditions (uncertainties) that could exist over the long time frames considered. 


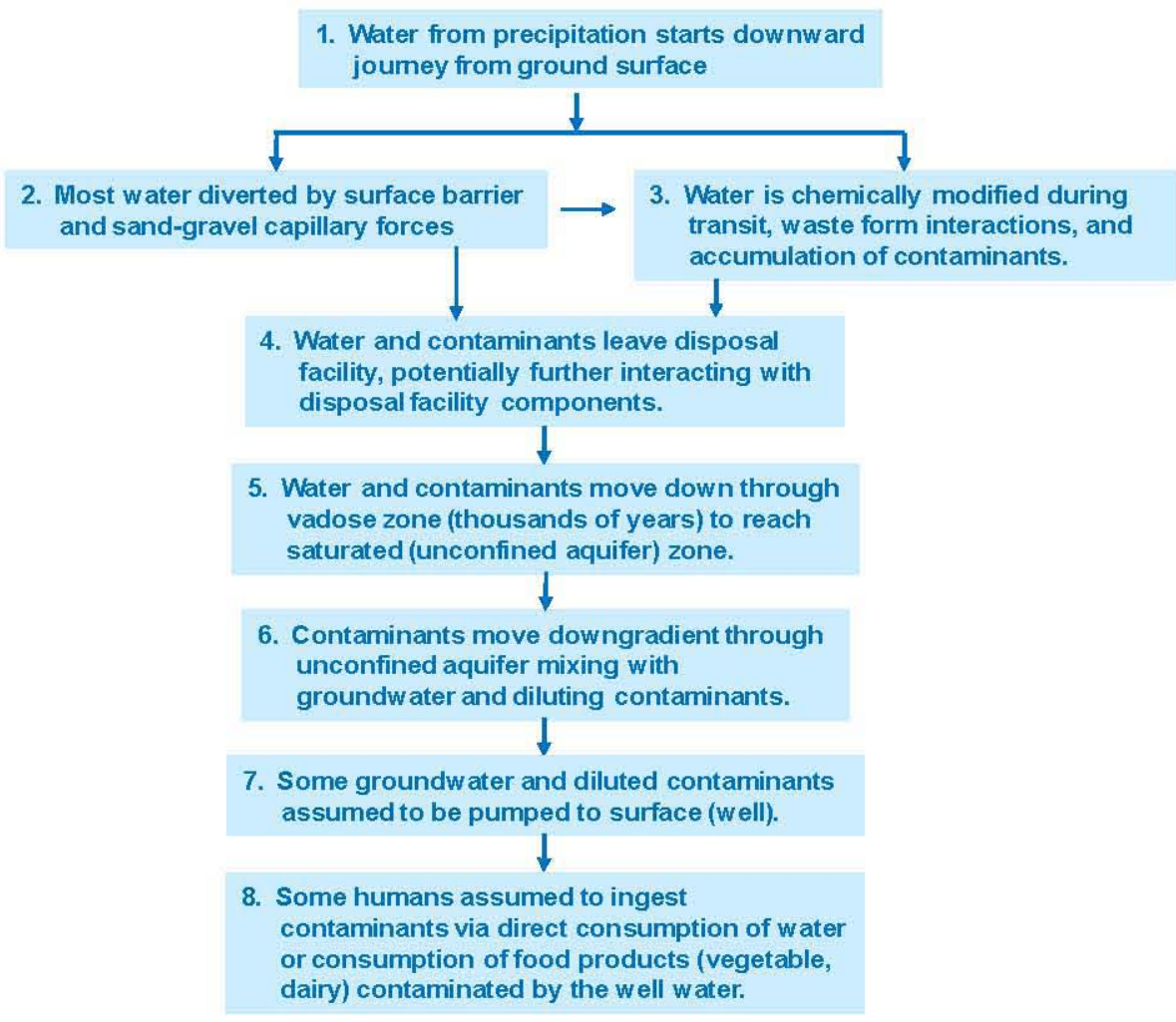

Figure 1-4. Eight Steps Assumed in Performance Assessment Groundwater Pathway Models

Such uncertainties include long-term climate changes that affect rainfall; long-term effectiveness of surface barriers that promote evaporation of precipitation over penetration into native soils; chemical reactions between the groundwater and soils and waste forms disposed of in the facility; influence of human-caused changes involving land use, technology, and current food chain-based predictive model applicability; and other currently unforeseen factors.

The PA analyses ultimately result in projections of doses to members of the public in close proximity to the disposal facility (e.g., drinking water or eating vegetables using water from a well adjacent to the disposal facility), lifetime cancer risks, and radionuclide concentrations; all of which are measured against established regulatory standards. The regulatory performance objectives or standards typically used are listed in Table 1-2 which was derived from RPP14283, Performance Objectives for Tank Farm Closure Performance Assessments. 
Table 1-2. Key Performance Objectives for Performance Assessment

\begin{tabular}{|c|c|}
\hline \multicolumn{2}{|c|}{ Protection of General Public and Workers ${ }^{a, b}$} \\
\hline All-pathways dose from only this facility & 25 mrem in a year ${ }^{\mathrm{c}, \mathrm{d}}$ \\
\hline All-pathways dose including other Hanford Site sources & $100 \mathrm{mrem}^{\text {in a year }}{ }^{\mathrm{e}, \mathrm{d}}$ \\
\hline Chemical Carcinogens (Incremental Lifetime Cancer Risk) & $10^{-5} \mathrm{c}, \mathrm{f}$ \\
\hline Non cancer-cause chemicals (hazard index) & $1^{\mathrm{c}, \mathrm{f}}$ \\
\hline \multicolumn{2}{|c|}{ Protection of an Inadvertent Intruder ${ }^{\mathrm{a}, \mathrm{g}, \mathrm{h}}$} \\
\hline Acute and Chronic exposure & 500 mrem \\
\hline \multicolumn{2}{|c|}{ Protection of Groundwater Resources ${ }^{\mathrm{a}, \mathrm{b}, \mathrm{e}, \mathrm{i}}$} \\
\hline \multicolumn{2}{|l|}{ Alpha emitters } \\
\hline${ }^{226} \mathrm{Ra}$ plus ${ }^{228} \mathrm{Ra}$ & $5 \mathrm{pCi} / \mathrm{R}$ \\
\hline All others (excluding $U$ ) & $15 \mathrm{pCi} / \mathrm{R}$ \\
\hline $\mathrm{U} 30 \mu \mathrm{g} / \mathrm{R}$ & $30 \mu g / R$ \\
\hline Beta and photon emitters & $4 \mathrm{mrem}$ in a year \\
\hline \multicolumn{2}{|c|}{ Protection of Surface Water Resources ${ }^{a, b, j}$} \\
\hline \multicolumn{2}{|l|}{ Alpha emitters } \\
\hline${ }^{226}$ Ra plus ${ }^{228} \mathrm{Ra}$ & $0.3 \mathrm{pCi} / \mathrm{R}^{\mathrm{i}}$ \\
\hline All others (excluding $U$ ) & $15 \mathrm{pCi} / \mathrm{R}^{\mathrm{i}}$ \\
\hline Beta and photon emitters & 1 mrem in a year ${ }^{\mathrm{k}}$ \\
\hline \multicolumn{2}{|c|}{ Protection of Air Resource ${ }^{b, h, 1}$} \\
\hline Radon (flux through surface) & $20 \mathrm{pCi} \mathrm{m}^{-2} \mathrm{~s}^{-1}$ \\
\hline All other radionuclides & $10 \mathrm{mrem}$ in a year \\
\hline \multicolumn{2}{|c|}{ 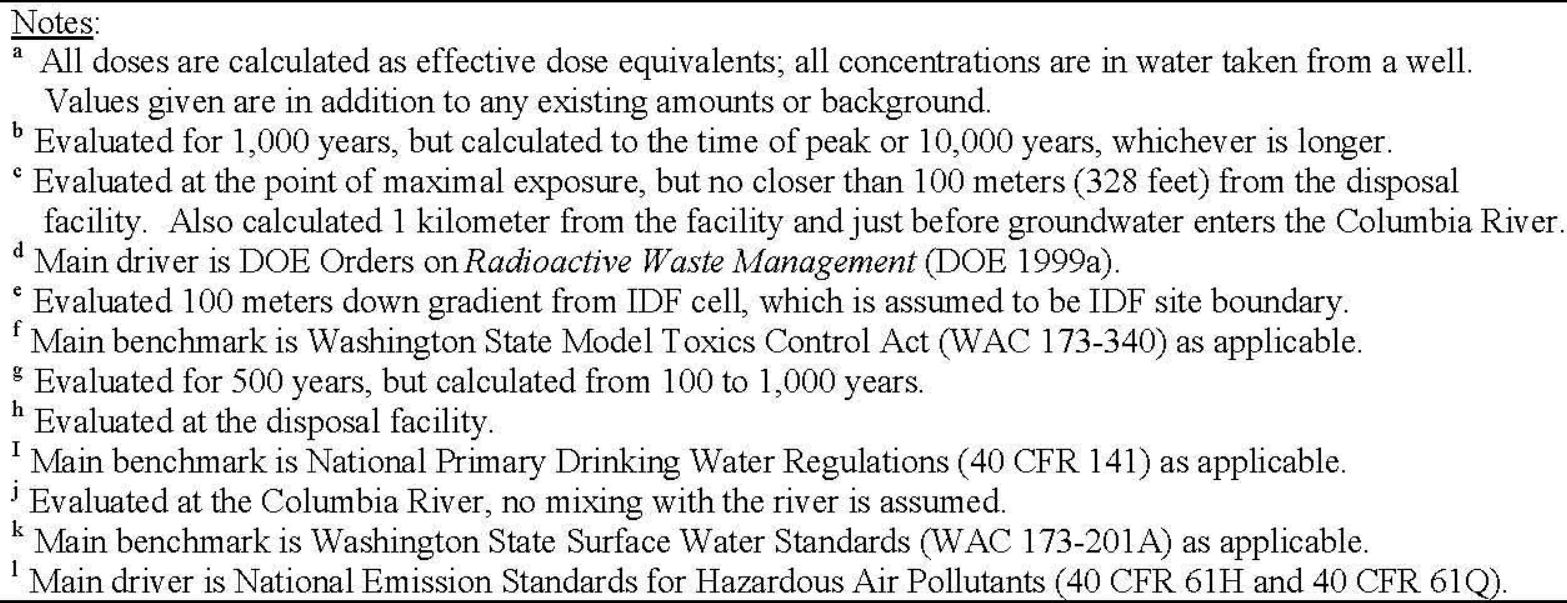 } \\
\hline
\end{tabular}




\subsection{DESIRED ATTRIBUTES OF SELECTED TECHNOLOGIES}

Any technology selected to immobilize Hanford LAW should have the following attributes:

- RCRA Compliant: Can be demonstrated to perform on an equivalent level to HLVIT standards under RCRA such that EPA DET approval is likely.

- Robust treatment: Ability to treat and immobilize the spectrum of LAW chemical and radioactive constituents anticipated to be in LAW feed.

- Operationally Stable: Minimal need for operator adjustments to system during operations for any given batch of feed.

- Predictable: Waste form performance characteristics can be adequately correlated to feed chemistry to support a Treatability Variance.

- Safe: Operationally reliable, stable, and predictable such that risks to operators, the public, and the environment are minimized.

- Durable waste form: Waste form controls release of radioactive and hazardous constituents to sufficiently low levels over sufficiently long time frames that projected impacts to human health and the environment are within applicable environmental regulatory standards.

- Cost Effective: Offers best value (capital and lifecycle costs) to the government considering whether the levels of performance, assurance, benefits, and risks inherent in the other parameters are listed above.

The remainder of this report is focused on the FBSR technology and why it is being considered for use at Hanford for the treatment and immobilization of LAW. 


\subsection{INTRODUCTION TO FLUIDIZED BED STEAM REFORMING}

Steam reforming is a process that has been used at production levels in the petrochemical industry for nearly a century. Steam reforming was invented by an Italian physicist, Felice Fontana, in 1790 as a means of producing hydrogen from hydrocarbons using steam in a catalytic oxidation process. Steam reforming moved into industrial usage in the $1920 \mathrm{~s}$ when BASF $\mathrm{SE}^{8}$ of Germany used steam reforming to produce methane using hydrogen derived from lignite. Steam reforming has been widely used since that time for petroleum cracking and, more recently, for the treatment of radioactive and hazardous wastes.

\subsection{WHAT IS STEAM REFORMING?}

Steam reforming creates a reaction between high temperature steam and organic materials in an oxygen deficient environment. The reforming reaction breaks down the organic materials without combustion. As discussed later in this report, FBSR has been selected to treat certain DOE tank wastes at INL and SRS and is a candidate technology for use at Hanford as well.

Steam reforming has long been used in the petrochemical industry to harvest hydrogen gas from methane. In a basic steam reformation process, energy from high temperature (superheated) steam creates an oxygen deficient reaction between water and a hydrocarbon to form hydrogen gas and carbon dioxide.

There are many types of steam reformers, each specifically designed to achieve a desired outcome such as producing bulk hydrogen for the synthesis of ammonia or for use in hydrogen fuel cells. The DOE Office of Energy Efficiency and Renewable Energy reports that approximately $95 \%$ of hydrogen produced today in the United States is made using steammethane reforming, a process in which high-temperature steam is used to produce hydrogen from a methane

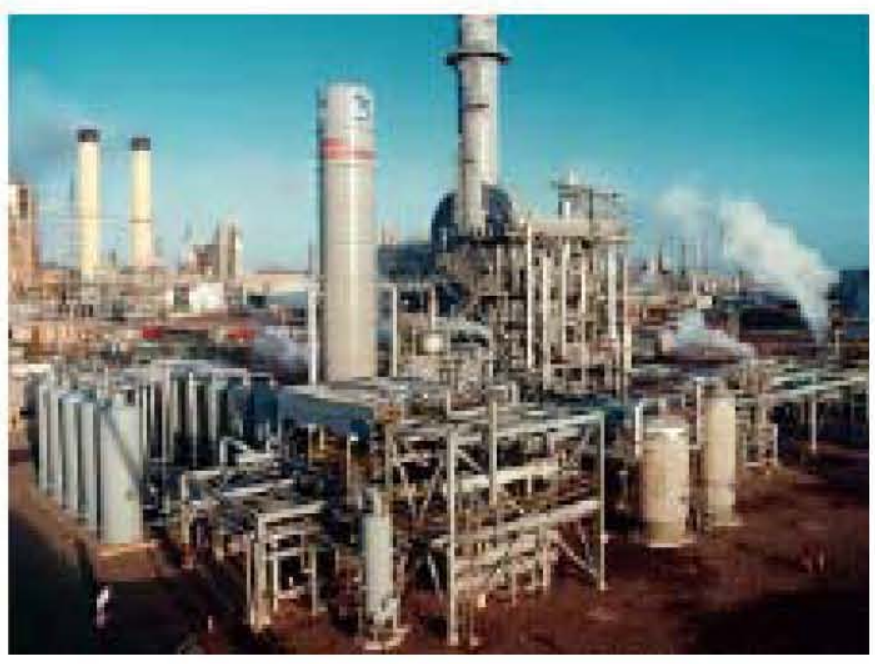

Figure 2-1. Commercial Steam Reforming to Produce $\mathrm{H}_{2}$ Gas source such as natural gas (Figure 2-1 from http://www.getenergysmart.org/files/hydrogen education 6 hydrogenproductionsteammethanereforming.pdf.

\footnotetext{
${ }^{8}$ BASF SE, headquartered in Germany, is the largest chemical company in the world.
} 
For example, between $700^{\circ}$ to $1000^{\circ} \mathrm{Cel}$ sius with nickel $\left(\mathrm{N}_{1}\right)$ as a catalyst, steam reacts with methane to produce hydrogen as depicted in the formulas bel ow:

$\underline{\mathrm{CH}_{4}}($ methane $)+\underline{\mathrm{H} Q \underline{Q}}$ (high temperature steam) $\rightarrow \underline{\mathrm{CO}}$ (carbon monoxide) $+3 \underline{\underline{H}}$ (hydrogen gas)

Then, in a second reaction:

$\underline{\mathrm{CO}}+\underline{\mathrm{H}_{2} \mathrm{O}}$ (high temperature steam) $\rightarrow \underline{\mathrm{CO}}_{2}$ (carbon dioxide) $+\underline{\mathrm{H}}_{2}$

This is one of a large number of applications of steam reforming to industrial processes to create chemical feedstock required for energy and commercial products.

\subsubsection{What is a Fluidized Bed Reformer}

When gas flows upward through granular materials at a sufficient velocity such that the granules begin to be lifted upward, a process known as fluidization occurs. At that point the granules start to exhibit properties that are more like a fluid than a solid mass.

In industry, the equipment that is used to fluidize a bed of solid materials is commonly referred to as a fluidized bed reformer. In the bottom of the fluidized bed reformer there is typically a porous distributor plate or set of injectors that distribute the gas to uniformly pass it through a bed of solid granul ar materials rather than create a flow channel through the bed that would push the granular materials to the side. As the gas pressure is increasedits upward velocity through the bed increases to a point where the upward force of the gas on the granules is sufficient to offset the pull of gravity on the granules. Beyond this point, the solid granule bed starts to expand and move like a fluid and a fluidized bed condition has been achieved.

The fluidized bed concept is illustrated in Figure 2-2. Fluidization of the bed can be achieved by gas flow through a distributor plate or injectors below the bed of solid particles. In industry, the principal advantages of a fluidized bed include uniform particle mixing, uniform temperature gradients throughout the bed, and the ability to operate the reformer in a continuous (rather than batch) mode (1989, J.R. Howard, Fluidized Bed Technology: Principles and Applications).

Additional advantages include:

- Uniform, predictable reactions and consistent product characteristics,

- Complete mixing (fluid-like behavior),

- Better fluid-solid contact,

- Uniform temperature gradients,

- High heat transfer coefficients (efficient), and

- High degree of control.

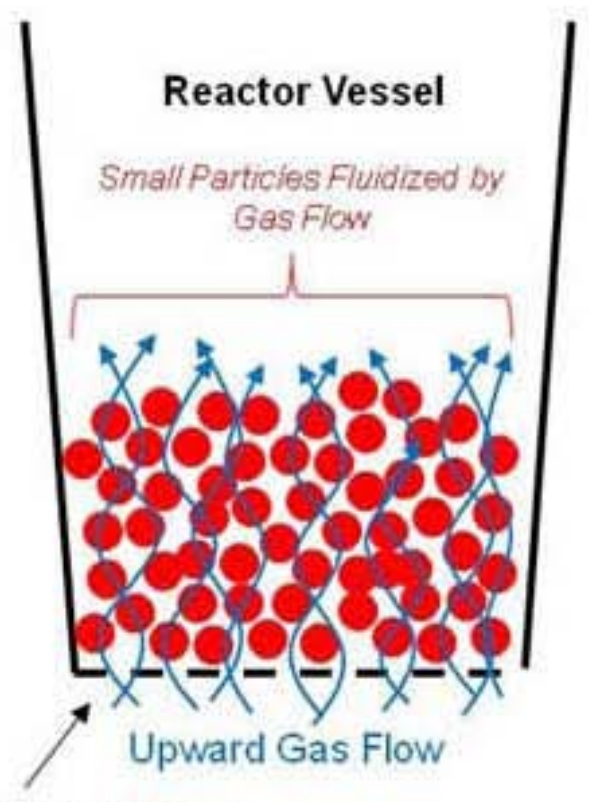

Perforated Media to

Distribute Gas Flow

\section{Figure 2-2. Simplified Depiction of the Fluidized Bed Concept}


Fluidized bed processes came into widespread use during the Second World War when aviation grade gasoline was needed in large quantities. While it had been long recognized that high velocity gas flow could propel solid powder materials through tubes, Warren K. Lewis and Edwin R. Gilliland of the Massachusetts Institute of Technology, while working with Standard Oil Company of New Jersey during World War II, suggested that a low velocity gas flow through a powder might "lift" it enough to cause it to flow in a manner

Using high temperature steam as a fluidizing agent integrated the benefits of fluidized bed processing with steam reformation. This was a key breakthrough that enabled steam reformation of radioactive waste on a continuous basis. similar to a liquid. From their theory a fluidized bed "petroleum cracker" was developed for use in the Baton Rouge Refinery of the Standard Oil Company of New Jersey (now Exxon Corporation). It successfully came on line in 1942. Today over 350 fluidized bed reformers are operating worldwide for the manufacture of petroleum based fuels, chemicals, and plastic materials (2010, American Chemical Society, On Line Education Series, The Fluid Bed Reactor), as well as for food production and waste management. The use of high temperature steam as a fluidizing agent enabled engineers to integrate the benefits of fluidized bed processing with the steam reformation process.

\subsubsection{What is Pyrolysis}

Pyrolysis refers to the thermo-chemical decomposition of organic materials at elevated temperatures in the absence of oxygen ${ }^{9}$. Pyrolysis typically occurs under pressure and at operating temperatures above $430^{\circ}$ Celsius. The word is coined from the Greek-derived elements pyr "fire" and lysis "separating".

Pyrolysis is used heavily in the chemical industry to produce charcoal, activated carbon, methanol, and other chemicals from wood. Pyrolysis differs from other high-temperature processes, like combustion, in that it does not involve reactions with oxygen, water, or other reagents. The term has also been applied to the decomposition of organic material in the presence of superheated water or steam (hydrous pyrolysis), for example in the steam cracking of oil.

Accordingly, the steam reforming process can be used to decompose complex chemical compounds into simpler chemical forms without combustion. This capability opened the potential for pyrolysis via steam reforming to treat radioactive wastes with high organic content that would benefit from volume/mass reduction, e.g., ion exchange resins.

\subsection{WHY FBSR IS BEING CONSIDERED AT HANFORD}

As previously discussed in Section 1, DOE, Ecology, and the EPA conducted a series of meetings/workshops in 2002 to determine whether Bulk Vitrification, Cast Stone, or FBSR should be further developed as technologies to supplement the WTP LAW vitrification plant to complete the treatment mission. Considering cost, maintainability, operability, and other factors,

\footnotetext{
${ }^{9}$ In practice it is not practical to achieve a completely oxygen-free atmosphere (a small amount of oxygen is present in any pyrolysis system) so a small amount of oxidation occurs, however, the predominant reactions do not involve oxidation.
} 


$$
\text { RPP-48903, Rev } 0
$$

the DOE Office of River Protection (ORP) elected to proceed with further tests of Bulk Vitrification at Hanford. Bulk vitrification remains a candidate technology.

Based on preliminary test data, the FBSR technology appears to produce a highly durable mineral waste form. Accordingly, FBSR continues to be under consideration for treating certain Hanford tank wastes including LAW and secondary liquid wastes from LAW vitrification.

\subsection{HOW FBSR WORKS}

\subsubsection{Feed Preparation}

Supernatant (liquid waste) from Hanford DSTs needs pretreatment to create a suitable LAW feed stream for treatment and immobilization. The pretreatment required for FBSR is essentially the same as would be required for the other candidate technologies.

The first pretreatment step is solids/liquid separations using micro- or ultrafiltration. This step serves two important purposes:

1) Filtration removes insoluble radionuclides, principally transuranic radionuclides and Sr-90.

2) Filtration also clarifies (removes solids) from the supernatant that could create process issues with the second pretreatment step.

The second pretreatment step is ${ }^{137} \mathrm{Cs}$ removal. This can be accomplished by any of several technologies including ion exchange and solvent extraction. A project is underway to determine the best path forward for pretreating LAW prior to supplemental immobilization.

The pretreated LAW will be sufficiently low in key radionuclides that it will no longer exhibit the "highly radioactive" characteristics associated with HLW. The low radioactivity levels associated with the pretreated LAW are critical to DOE being able to make a formal WIR determination as discussed in Section 1.6.3, i.e., once solidified and demonstrated to meet the DOE M 435.1-1 criteria the immobilized LAW will not be HLW.

Up to this point, the pretreatment approach is identical for all four supplemental immobilization approaches under consideration.

Once pretreated, the liquid LAW feed to a FBSR system would be staged in receiver tanks and mixed with clay to form LAW/clay slurry. That slurry will be fed to the Denitration \& Mineralizing Reformer (DMR). 
Figure 2-3 depicts the FBSR process in a simplified configuration applicable to Hanford LAW. An overview of the treatment process is provided below.

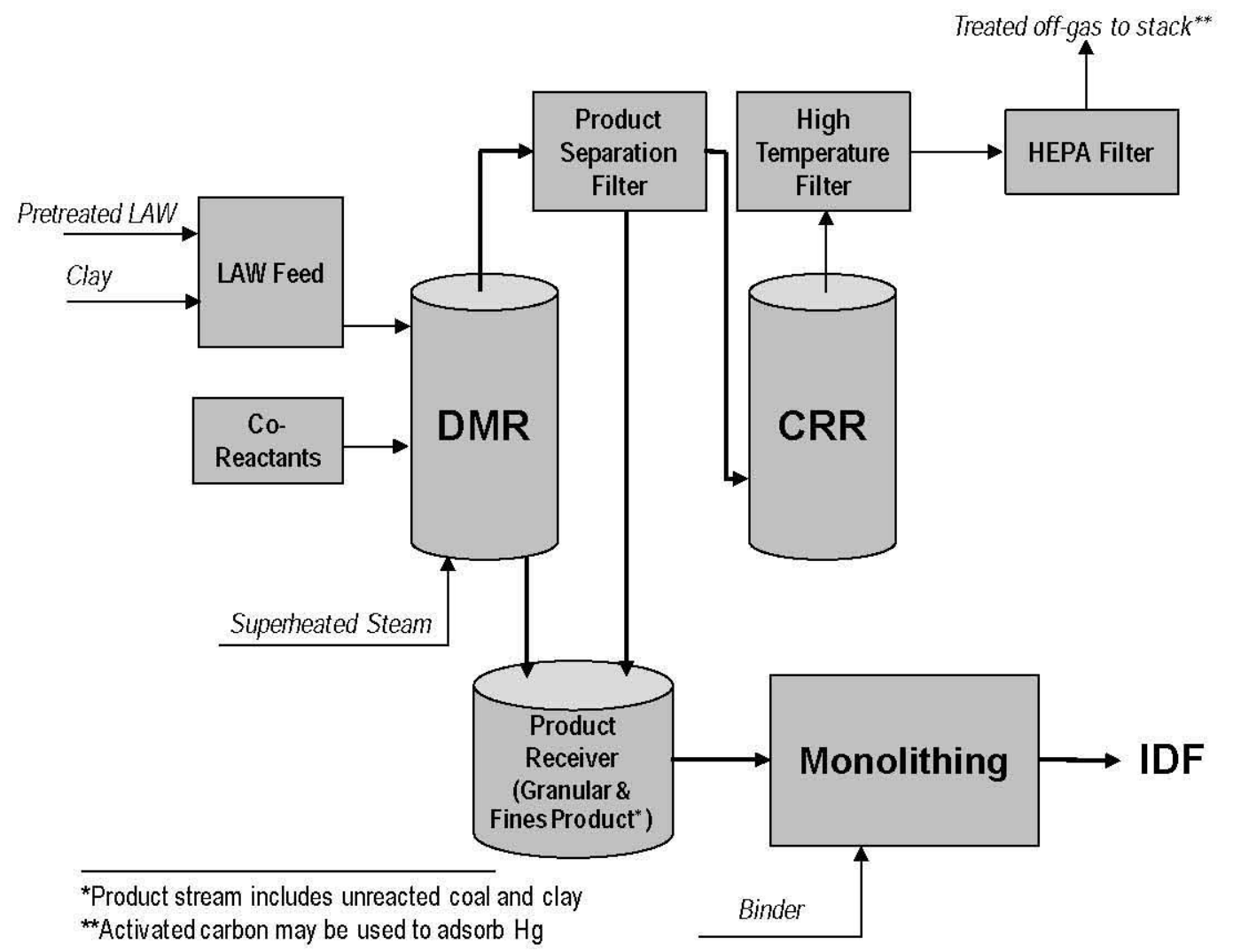

Figure 2-3. Simplified Depiction of the FBSR Process to Produce a Mineral Waste Form

\subsubsection{Immobilization Process Overview}

The DMR is a thermal treatment vessel in which the key FBSR reactions occur. In the DMR 1) liquids are evaporated; 2) organics are volatilized and converted into shorter chain organic species, hydrogen, carbon monoxide, and carbon dioxide; 3) nitrates and nitrites are converted directly into nitrogen gas, with very little $\mathrm{NO}_{\mathrm{x}}$; and 4) radionuclides, alkali metals, non-volatile heavy metals, sulfates, chlorides, fluorides, and phosphates are captured in the solid product.

The pretreated LAW feed/clay slurry is injected into the DMR. In parallel, co-reactants (principally a carbon source such as coal ${ }^{10}$ ) are injected into the DMR and superheated steam and nitrogen gas $\left(\mathrm{N}_{2}\right)$ are injected into the bottom of the DMR. The superheated

The DMR is the heart of the FBSR system. It is the reformer where feed materials are converted into the mineral product streams; the granular product that exits from the bottom of the DMR and the fines removed in the PSR. Both streams are collected in the PR.

\footnotetext{
${ }^{10}$ Although for simplicity "coal" is referred to throughout this report, in practice, other carbon sources could also be used. A decision has not been made regarding the carbon source that would be used if FBSR is selected for Hanford waste immobilization.
} 
steam and $\mathrm{N}_{2}$ provide the gaseous up-flow required to fluidize the bed. The coal reacts with oxygen to give off heat, which provides the bulk of the energy required for the FBSR mineralization and other processes to occur.

In the DMR some chemical bonds in the clay $\left.\underline{\underline{A l}}_{2} \underline{\mathrm{Si}}_{2} \underline{\mathrm{O}}_{5}(\underline{\mathrm{OH}})_{4}\right]$ are altered, which allows some metals and non-metallic chemicals in the waste to substitute in the former clay structure. In this process feldspathoid minerals are formed in both granular and fines form. The granular and fines have the same mineral structures.

Because the DMR operates under reducing conditions, many chemical compounds in the feed are broken down to less complex chemical or even elemental forms. For example, nitrates/nitrites in the LAW feed are reduced to $\mathrm{N}_{2}$, which eliminates the need for $\mathrm{NO}_{\mathrm{x}}$ scrubbing. Other chemicals in the feed react to form sodium aluminosilicate minerals of the feldspathoid class as discussed later in this report. For example, sulfur (S) in the feed reacts to form nosean sodalite $\left[\left(\mathrm{NaAlSiO}_{4}\right)_{6} \mathrm{Na}_{2}\left(\mathrm{SO}_{4}\right)\right]$ which eliminates the need for a scrubber to remove $\mathrm{SO}_{\mathrm{x}}$ from the FBSR off-gas stream.

The heavier granular product tends to remain in the fluidized bed while most of the fines are lifted out of the bed by the gas flow as illustrated in Figure 2-4.

As the fluidized bed grows in size, granular (and some fines) product are periodically removed from the bottom of the DMR using an auger/grinder. The material is pneumatically transferred to the Product Receiver (PR) along with unreacted coal and unreacted clay from the bed using $\mathrm{N}_{2}$ as the transport gas.

Process gases leaving the DMR consist mostly of steam, $\mathrm{N}_{2}$ (from process reactions, instrument purges, and fluidizing gases), carbon monoxide (CO), carbon dioxide $\left(\mathrm{CO}_{2}\right), 0.5 \%$ to $4 \%$ hydrogen gas $\left(\mathrm{H}_{2}\right)$, and very low levels of $\mathrm{NO}_{\mathrm{x}}$, acid gases, and short chain organics. Some carbon and mineral product fines exit the top of the DMR with the process gases. The DMR process gas stream is filtered through the Product Separation Filter (PSR), where the entrained fines product and unreacted carbon are removed from

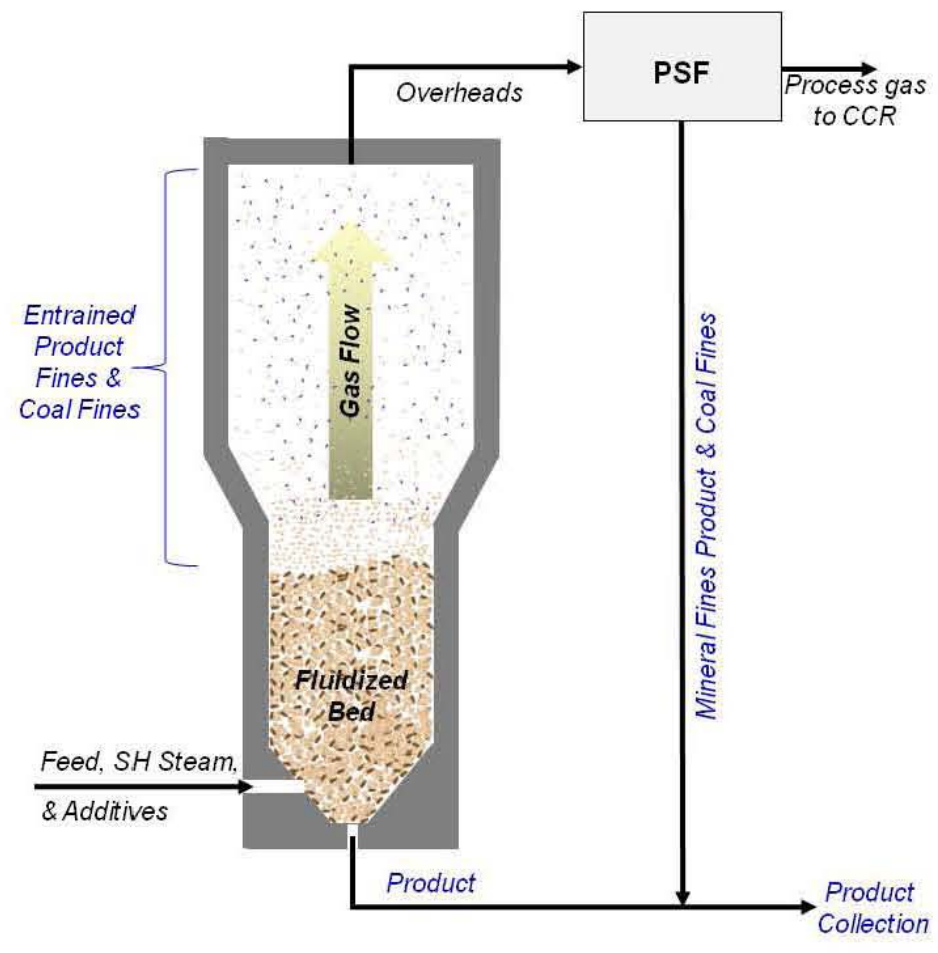

Figure 2-4. Simplified Depiction of FBSR Fines Entrainment, Separation in Product Separation Filter, and Recombination with FBSR Product Stream

the gas and transferred to the PR. 
Fines - Fluidized conditions exist within the DMR because of the steam up-flow through the DMR bed. The steam and other gases formed during the mineralizing reactions continue to flow upward through the DMR until they exit at the top. As illustrated in Figure 2-4, small particl es can become entrained in the upward moving gases, leave the fluidized bed, enter the wider disentrainment zone within the DMR. Those that do not fall back into the fluidized bed will be carried out of the DMR. This includes fine mineral particles that were captured by the gas stream before growing into larger granules as well as fine particles of unreacted coal. This is an expected condition for FBSR reaction environments.

Researchers have noted that the granular and fines materials produced consist of the same (targeted) mineral phases. (INEEL/EXT-04-02492, 2004, "Fludized Bed Steam Reforming of Hanford LAW Using THORSM Mineralizing Technology") Further, both the granular and fines perform at comparable durability levels to LAW glass. (WSRC-TR-2005-00102, 2005, "Durability Testing of Fluidized Bed Steam Reformer (FBSR) Waste Forms for High Sodium Wastes at Hanford and Idaho"; WSRC-STI-2006-00033 Revision 1, 2006, "Fludized Bed Steam Reformer (FBSR) Product: Monolith Formation and Characterization").

The product stream will be pneumatically transferred from the PR to a process area where the product will be converted to a monolithic form. In the monolithing station the product will be mixed with a binder in a pug mill and then extruded into large carbon steel containers where it will cure into a final waste form.

\subsubsection{Waste For $m$ Description}

The mineralized product stream collected in the PR during FBSR operations is made up of sodium aluminosilicate (NAS) minerals (granular and fines) as well as unreacted clay and carbon. Figure 2-5 is a photograph of product material withdrawn from Hazen Research pilotscale production runs with Hanford LAW simulant from RT-21-002, 2009, Report for Treating Hanford LAW and WTP SW Simulants: Pilot Plant Mineralizing Flowsheet. A 5$\mathrm{mm}$ scale is visible in the lower right portion of this photograph. The large dark particles are carbon used as an energy source and reductant in the DMR. Fine solids elutriated from the DMR bed were collected in the PSF and periodically removed and added to the product stream.

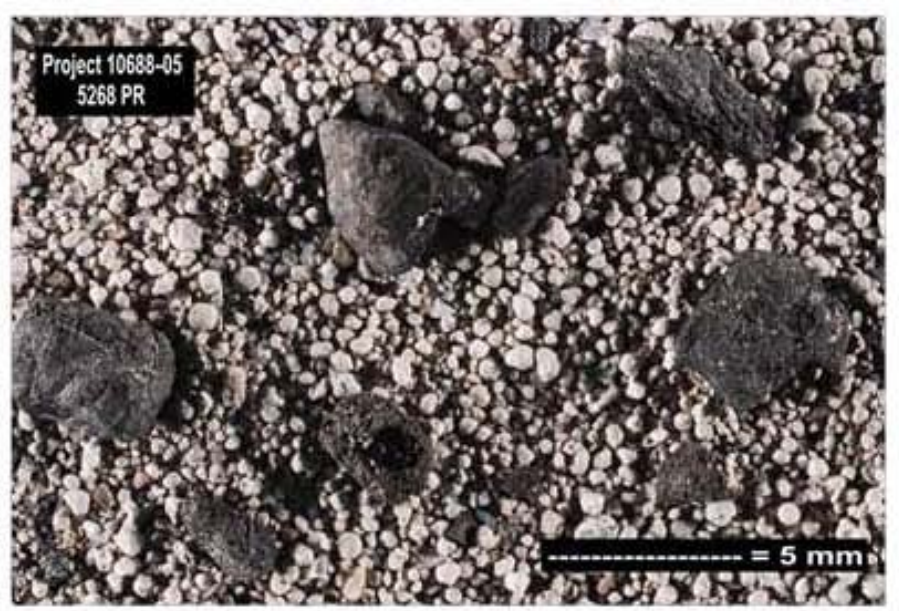

Figure 2-5.Photo of Typical S ample Material from FBSR including Granular, Fines, Clay, and Carb on 


\subsubsection{Why Produce a Mineral Waste Form}

In 2002 the THOR ${ }^{\circledR}$ FBSR process was evaluated by the WTP contractor at Hanford as a means of pretreating feed to the LAW melters in order to increase melter efficiency. The initial intent was to remove sulfates and nitrates from the LAW melter feed which would have simplified off-gas treatment and increased the LAW melter throughput. During tests with a LAW surrogate the very high $\mathrm{Na}$ content typical of Hanford tank wastes resulted in the formation of a sticky material ${ }^{11}$ that was difficult to continually process through the system. Among the techniques tested to prevent buildup of the sticky material was the addition of high alumina clay. The objective was to tie up the $\mathrm{Na}$ in a Na-Al-silica compound that would flow more freely through the system.

When clay was blended with Hanford LAW surrogate feed in the FBSR process, it was discovered that a waste form was produced that was composed of various $\mathrm{Na}$ aluminosilicate (Na-Al-Si or NAS) minerals that are within the feldspathoid class. Feldspathoids are similar to zeolites in that both have large openings in the crystal structure. However, the openings in feldspathoids are separated from each other and do not enable the movement of ions and molecules within the structure as do zeolites. The openings (cages) hold large ions such as $\mathrm{Cl}$, carbonate, and sulfate within the cages. The mineralized product had properties that were potentially suitable for direct disposal as a waste form rather than as an interim step towards a vitrified waste form.

The primary mineral constituents formed during the FBSR process from the combination of Hanford LAW and clay are nepheline, sodalite, and nosean.

McGrail (PNWD-3288, 2003, Initial Evaluation of Steam-Reformed Low-Activity Waste for Direct Land Disposal) performed the initial scientific analyses of the FBSR mineralized waste form produced from Hanford LAW surrogate. McGrail theorized that the rhenium (surrogate for

${ }^{99} \mathrm{Tc}$, which has no non-radioactive isotopes, was trapped in the nosean cages based on the ability of nosean to capture large ions (as discussed above) as well as non-congruent dissolution properties noted during laboratory testing. Other scientists including Jantzen (Jantzen 2004) have made the same observations based on different FBSR runs and subsequent waste form tests. Current theory is that sodalites (including nosean) are the host minerals for halides, ${ }^{99} \mathrm{Tc}$, and sulfate/sulfide. Nepheline appears to be the host for the remaining alkali ${ }^{12}$ materials.

11 This same stickiness issue was noted at INL when high $\mathrm{Na}$ wastes were fed to the calciner as noted in the following excerpt: "Technical difficulties stymied efforts to calcine Na-bearing waste. Waste containing Na is more difficult to calcine, because Na makes the calciner mixture gummy instead of dry. Because the calciner moves the material being treated by air, this gumminess tends to clog the system, requiring more shutdowns for maintenance." Idaho Department of Environmental Quality, About INL Facilities: Calciner History and Issues, http://Www.deq.idaho.gov/inl oversight/about/facilities/calciner history issues 000.cfm\#Na.

${ }^{12}$ Alkali refers to materials containing chemical elements from Group 1 of the periodic table: lithium (Li), sodium $(\mathrm{Na})$, potassium $(\mathrm{K})$, rubidium $(\mathrm{Rb})$, cesium $(\mathrm{Cs})$, and francium $(\mathrm{Fr})$. 
Tests are being conducted on the mineralized waste forms produced from bench-scale tests at SRNL during fiscal year 2011 to ascertain that nosean is the host for ions such as rhenium and ${ }^{99} \mathrm{Tc}$. While it is not imperative ${ }^{13}$ that radioactive species such as ${ }^{99} \mathrm{Tc}$ and ${ }^{129} \mathrm{I}$ are captured in sodalite/nosean cage structures, it would be useful to help explain the low release rates of those radionuclides from the FBSR waste form measured during laboratory tests that simulate very long-term exposure to groundwater.

\subsubsection{Why Mineralized Waste Forms Are Late Comers to Radioactive Waste}

The discussion of minerals/ceramics to encapsulate radioactive materials dates back to a National Academy of Sciences panel convened at the request of the NRC in 1976 to evaluate potential waste forms for high-level radioactive waste. One panel member, Dr. Rustum Roy (professor at Pennsylvania State University) made compelling arguments for the use of mineral/ceramic waste forms. Nonetheless, clay-based ceramic/mineral waste forms were not pursued for radioactive waste treatment until the latter part of the $1990 \mathrm{~s}$. This was, in part, because there were no continuous commercial technologies available that could create the prerequisite hydrothermal environments to produce the waste forms (Lutze, 1988, Radioactive Waste Forms for the Future) on a mass production basis. On the other hand, continuous vitrification processes were available and could be reasonably adapted to incorporate HLW into a borosilicate glass matrix.

When Studsvik AB (Studsvik) built an FBSR facility in Erwin, Tennessee using its THOR ${ }^{\text {sm }}$ process to pyrolyze spent ${ }^{14}$ organic resins from commercial nuclear facilities, it was the first continuous radioactive waste steam reformer put into operation. It was subsequently learned that introducing kaolin clay into the FBSR process could produce a mineral waste form that converted radioactive waste to a mineral waste form on a continuous basis. While this has been demonstrated at the laboratory, pilot, and engineering scales, there are no commercial scale facilities producing the mineral waste form. Hanford would be the first, if FBSR is selected for use with LAW or liquid secondary waste.

\footnotetext{
${ }^{13}$ If the waste form results in very low releases of key radionuclides, the position of various radionuclides is not critical. For example, there are no crystalline cages in an amorphous waste form such as borosilicate glass yet it provides excellent performance.

${ }^{14}$ Spent resins in this context refer to ion exchange resins that were used to remove radionuclides (such as ${ }^{137} \mathrm{Cs}$ ) from primary coolant and from waste streams in commercial nuclear power plants. When the resins become loaded with radionuclides a number of utilities chose to send the resins to disposal rather than regenerate (remove the radionuclides from the resins). This is an economic choice that factors in the additional cost of regeneration and the need to neutralize, treat, and dispose of the regeneration wastes.
} 


\subsubsection{What Is the Difference between Mineral and Glass Waste Forms?}

A comparison between glass and mineralized waste forms is provided below. The purpose of the comparison is to relate the mineral form to the more familiar (at Hanford) glass waste; not to suggest one to be preferable to the other.

Mineralized waste forms differ from glass in several important ways. Key among these differences is that minerals have crystalline structures, while glasses are amorphous (unstructured) and do not have crystalline structures. Many solids have a crystalline structure on microscopic scales. The molecules are arranged in a regular lattice. As the solid is heated the molecules vibrate about their position in the lattice until, at the melting point, the crystal breaks down, and the molecules start to flow. There is a sharp distinction between the solid and the liquid state that is separated by a first order phase transition, i.e. a discontinuous change in the properties of the material such as density.

As a liquid cools its viscosity normally increases. Usually when a liquid cools to below its melting point, crystals form and it solidifies. If the increase in viscosity is sufficient, however; it can impede crystallization and remain non-crystalline below its melting point because there are no nucleation sites to initiate the crystallization. If the viscosity rises sufficiently as the liquid cools further, it may never crystallize. Instead, the viscosity rises rapidly and continuously during cooling, becoming syrup-like and thickening, until an amorphous solid is formed. The molecules then have a disordered arrangement, but sufficient cohesion to maintain some rigidity. In this state it is often called an amorphous solid or glass and the molecules are unordered, i.e., the molecules do not

The degree to which a liquid flows is typically measured in terms of its viscosity, i.e., its resistance to flow. For example, the viscosity of water at room temperature is about 1 to 5 centipoises. Blackstrap molasses has a viscosity of about 5,000 to 10,000 centipoises and peanut butter has a viscosity of 150,000 to 250,000 centipoises at room temperature. Once molten glass is cooled to a solid form, it does not flow and has essentially infinite viscosity. exhibit a repeatable fixed structure. Accordingly, glass (such as the borosilicate glass that will be used to immobilize Hanford HLW and LAW) is typically referred to as an amorphous solid (Gibbs 1996). The amorphous nature of glass is illustrated in Figure 2-6 (from Glass and Other Ceramics", Purdue University website, http://chemed.chem.purdue.edu/genchem/topicre view/bp/materials/ceramic4.html\#top).

$00,000.000 .000 .08$

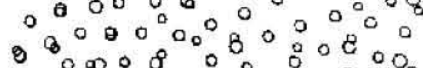
$0_{0}^{\circ} 0.00 .000 .0000000$ 0.808080 .000000 $00_{0} 0.000000 .000$ 00.000 .00000000 0.0000 .000000 $08 \% \frac{0}{0} 0.00000$ $\therefore 0.808800 .000$

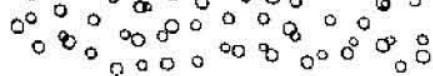

Figure 2-6. Molecular Arrangement in a Glass
The amorphous structure of glass is what makes glasses brittle, i.e., glasses do not contain planes of atoms that can slip past each other to relieve stress. Instead, glass particles at the surface of a crack become separated. The stress is then carried by particles with few neighbors over which the stress can be distributed. As a crack grows within a section of glass, the stress intensity at the forward tip of the crack continues to increase. This increased stress intensity and lack of relief results in the breaking of additional bonds, widening of the initial crack, and 
ultimately in a break in the section of glass (Purdue University website, "Glass and Other Ceramics").

Minerals have ordered crystalline structures such as illustrated in Figure 2-7 (1996, Philip Gibbs, "Is Glass Liquid or Solid'). Figure 2-7 depicts one of many possible crystalline structures that can exist in various minerals.

Minerals possess what are referred to as short range order (SRO), medium range order (MRO), and long range order (LRO). Glass has SRO and MRO but does not have LRO (WSRC-STI-2008-00268, 2008, Jantzen, C.M., Mineralization of Radioactive Wastes by Fluidized Bed Steam Reforming (FBSR); Comparisons to Vitreous Waste Forms and Pertinent Durability Testing). A solid is crystalline if it has LRO which means, in part, that once the positions of an atom and its neighbors are known at one point, the place of each atom is known precisely throughout the crystal due to

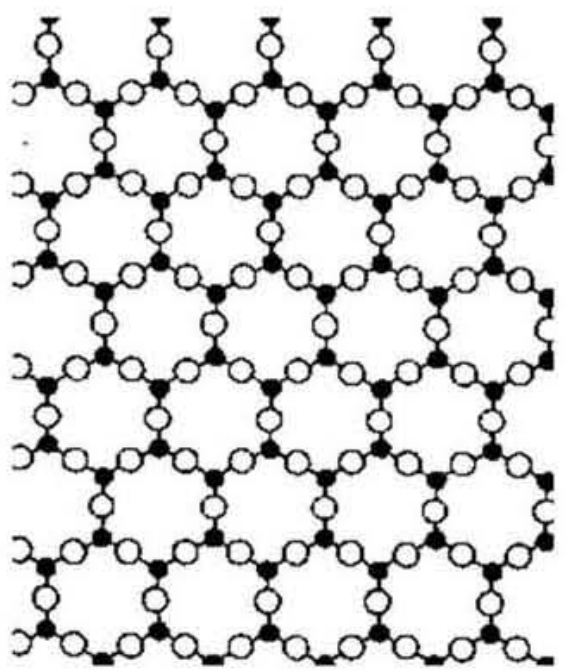

Figure 2-7. Molecular Arrangement in a Crystal the repeating crystalline patterns. Long-range order characterizes physical systems in which remote portions of the same sample exhibit correlated behavior, e.g., the repeating of the same crystal lattice beyond third neighbor environments, which gives crystalline minerals their crystallographic periodicity (Britannica On-Line Encyclopedia, "Long-and short-range order", http://www.britannica.com/EBchecked/topic/145105/crystal/51804/Long-and-short-range-order).

When Hanford LAW is reacted with clay in the FBSR process, NAS mineral structures are formed such as nepheline, sodalite, and nosean. The NAS minerals are formed from the combination of the $\mathrm{Na}$ in the $\mathrm{LAW}$ waste and $\mathrm{SiO}_{2}$ and $\mathrm{Al}_{2} \mathrm{O}_{3}$ contributed from the clay. Additional mineral phases may also be formed because of other waste constituents present in various LAW waste feeds such as phosphate, boron, iron, and other alkali or alkaline earth

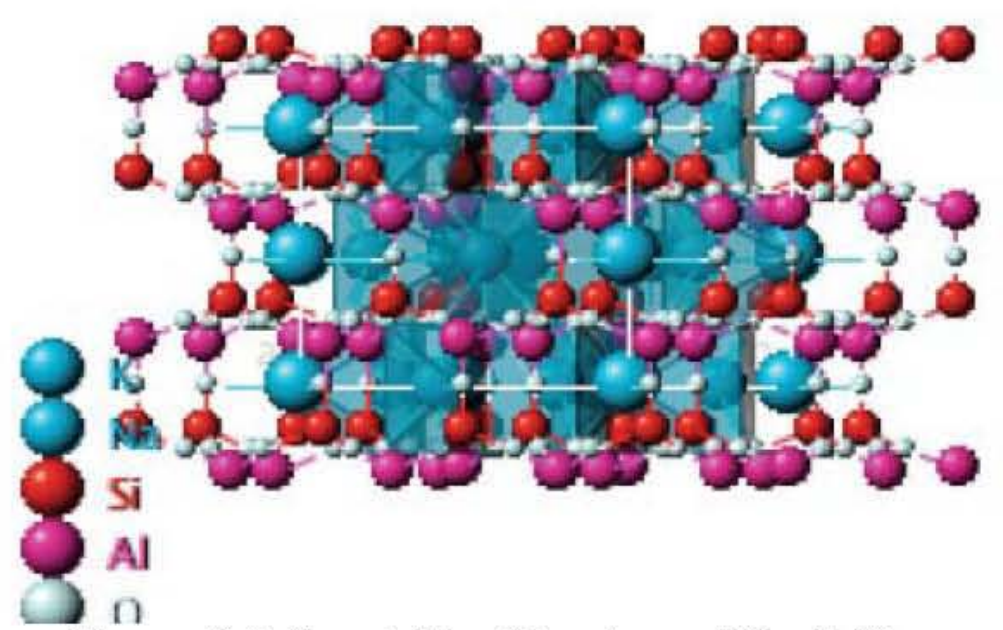

Figure 2-8. Crystalline Structure of Nepheline elements. Figure 2-8 illustrates the crystalline structures of nepheline (from 1947, "The Structure of Nepheline", M. J. Buerger, G. E. Klein, G. E. Hamburger, American Mineralogist, 32, p. 197).

Figure 2-9 illustrates the crystalline structures of nosean (from 1989, "The Structure of Nosean", H. D. Grundy, The Canadian Mineralogist, p. $165-172$ ).

The NAS cage minerals are formed by $\left(\mathrm{SiO}_{4}\right)^{-4}$ and $\left(\mathrm{AlO}_{4}\right)^{-5}$ sharing 
one or more of their four oxygen atoms with another tetrahedra $a^{15}$. The linking $0 x y g e n ' s$ are known as bridging oxygen bonds. The tetrahedra are arranged to form rings (e.g., nepheline in Figure 2-8) or a cage (e.g., sodalite/nosean in Figure 2-9). The other tetrahedral oxygen atoms (known as nonbridging oxygens) are available to bond ionically with the cations in the cage or outside the cage. These cations may be alkali, alkaline earths, hazardous, or radioactive species. The cage and/or ring structures are repeated in the structure at regular periodicity, which is the LRO characteristic of mineral/crystalline structures (WSRC-STI-2008-00268).

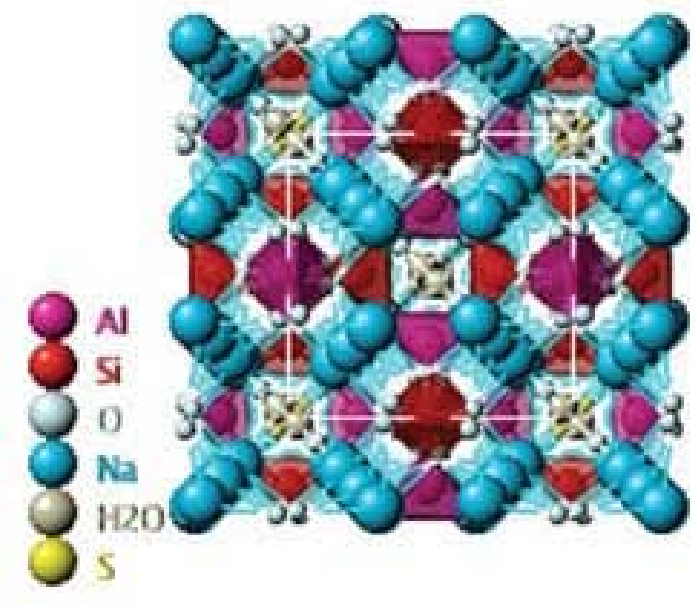

Figure 2-9. Crystalline Structure of Nosean

The rate of attack by water for either a glass or mineral waste form is controlled by the distribution of sites where ion exchange or hydrolysis can occur. That is, the locations where water can react with the waste form and the degree to which water has access to those sites. And, the extent to which water can contact the waste, react with it, carry away reaction products, and be replaced with new water to carry on the reaction.

Glass waste forms have percolation channels that are defined by the SRO and MRO. Mineral waste forms do not have percolation channels, water must attack the ionic bonds of the crystal lattice from the surface. For example, it is reported that the release of Na from crystalline nepheline is slower than its release from a glass that has an identical chemical composition (WSRC-STI-2008-00268).

The dissolution and contaminant release mechanisms for glasses and minerals are similar given the both have SRO and MRO. The existence of LRO in mineral waste forms, however, enables better retention of cationic species (as compared to glass) because of the regularity of the coordination and bonding of any given coordination polyhedra in which a cation (or radi onuclide) resides. While the activation energy required to break $\mathrm{Si}-\mathrm{O}, \mathrm{Al}-\mathrm{O}$, or $\mathrm{B}-\mathrm{O}$ bonds are similar in glasses and minerals due to the $\mathrm{SRO}$, the $\left(\mathrm{SiO}_{4}\right)^{-4},\left(\mathrm{BO}_{4}\right)^{-5},\left(\mathrm{BO}_{3}\right)^{-3}$ and $\left(\mathrm{AlO}_{4}\right)^{-5}$ are more strongly retained in minerals due to the LRO and periodicity (repeated pattern) of the polyhedra Accordingly, the LRO inherent in minerals, results in minerals being more thermodynamically stable than glass (WSRC-STI-2008-00268).

From a practical point of wiew, however, glass and mineral waste forms are both more substantially robust than waste forms typically used for low-level radioactive and mixed wastes and any differences in long-term performance are likely trivial given the uncertainties in the fate and transport of long-lived radionucli des as discussed in Section 1.7 .2

\footnotetext{
15 The term "tetrahedra" in this context re fers to refers to a crystalline struc ture with four triarg ular faces, three of which meet at each at each comer or intersection of the geometric shape.
} 


\section{RPP-48903, Rev 0}

Both glass and FBSR mineral waste forms are predicted to release contaminants slowly over millions of years. Any absolute differences in the long-term performance of glass waste forms currently considered for LAW and the NAS waste forms produced by FBSR are lost in the overlapping uncertainties associated with the analyses. Assuming effective immobilization of the radionuclides in the mineral structures, both waste forms should be sufficiently durable to perform essentially the same (well below current regulatory standards) in terms of very longterm, post-disposal, Hanford soil and groundwater environment.

\subsubsection{Surface Area}

The surface area that a waste form presents to the environment is important since the attack on the waste form by groundwater occurs at the surface for both minerals and glasses. As a result, the means by which surface area should be calculated has been the subject of numerous studies (DOE/ER/14547-1, 2002, Dissolution Rates and Surface Chemistry of Feldspar Glass and Crystal). For glasses, the geometric surface area adequately represents the overall glass surface area to be used in estimating long-term performance given the relatively smooth surface for a glass. This is not the case, however, for minerals. Minerals exhibit both a rough surface and porosity, both of which contribute to a higher reactive surface area, (i.e., the surface area that can react with groundwater).

McGrail (WTP-RPT-097, Rev 0, 2003, Initial Evaluation of Steam-Reformed Low-Activity Waste for Direct Land Disposal) recommended the use of the Brunauer-Emmet-Teller ${ }^{16}$ (BET) technique for estimating the reactive surface area for the FBSR mineralized waste form. While BET is a standard technique for measuring the surface area of finely divided and porous solids, there is still significant uncertainty associated with measurements of bulk BET surface area; (i.e., the actual reactive surface area is not always known). Pierce (Pierce 2007) indicates that a comparison of surface areas calculated using a geometric technique versus $\mathrm{N}_{2}$-adsorption $\mathrm{BET}$ illustrates the difference (Figure 2-10). For the FBSR mineral waste form the $\mathrm{N}_{2}$-adsorption BET surface area is approximately 200 times greater than the surface area calculated using geometric techniques.

Although use of the BET surface area may overestimate the true reactive surface area of the FBSR waste form, the microporosity associated with that waste form clearly indicates that using the geometric surface area would substantially underestimate the true dissolution rate and over predict its performance. Accordingly, there is general scientific agreement (Pierce 2007, Jantzen 2004, WTP-RPT-097), that dissolution rates for the FBSR mineralized product should be normalized to the BET surface area. Additional work would be required to better estimate the reactive surface area of the FBSR product if the conservatism associated with using the BET area is to be reduced.

\footnotetext{
16 The BET technique was developed by Stephen Brunauer, P.H. Emmet and Edward Teller in 1938 while working on ammonia catalysts to estimate the specific surface area of finely divided and porous solids. It has since become the standard method used for determining the reactive surface area of irregular and porous solids and other materials not amenable to simple geometric measurement techniques.
} 

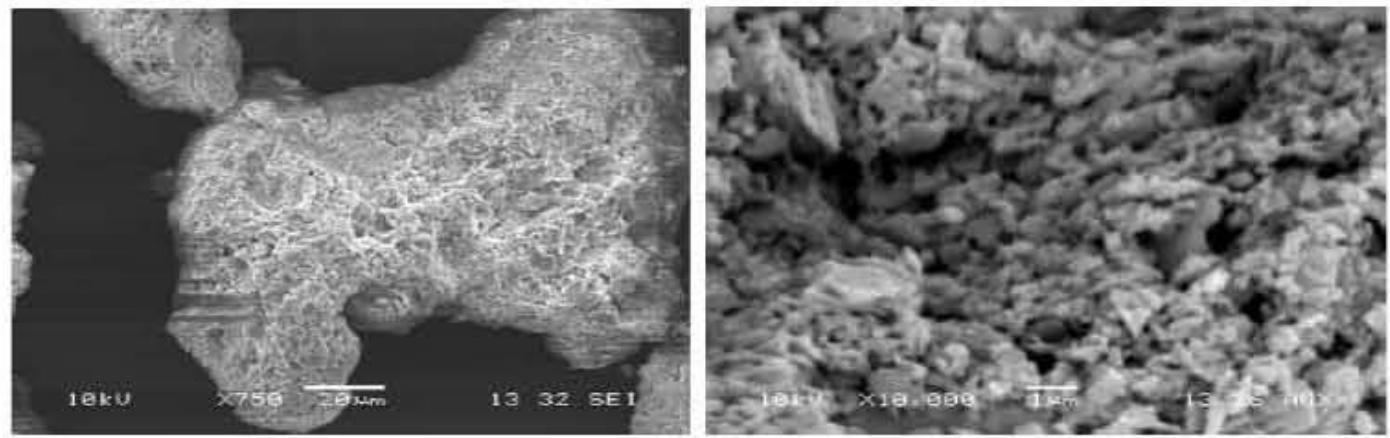

Scanning Electron Microscope image of a FBSR Mineralized Waste Form

Comparison BET and Geom etric Surface A rea for FBSR Mineralized Waste Form

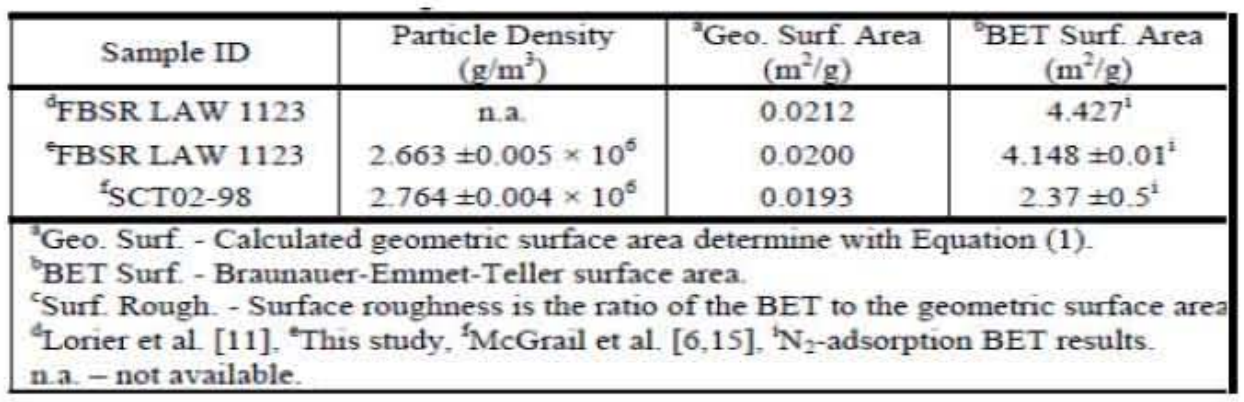

\section{Figure 2-10. Comparison of FBSR Surface Area Estim ation Techniques}

\subsubsection{FBSR Off-Gas Treatment}

Process gas from the DMR that flows through the PSF is treated in the Carbon Reduction Reformer (CRR). The CRR is operated at $\sim 950^{\circ}$ Celsius. The CRR contains a bed of alumina particles that is fluidized with the off-gases flowing from the DMR. The lower portion of the CRR operates in a reducing mode and the upper section operates in an oxidizing mode. In the lower section of the CRR residual $\mathrm{NO}_{\mathrm{x}}$ is reduced to $\mathrm{N}_{2}$ and remaining trace vol atile organics are reduced to more simple chemical or elemental forms. In the upper section of the CCR the gaseous mixture is largely converted to $\mathrm{CO}_{2}$ and $\mathrm{H}_{2} \mathrm{O}$ (as water vapor) plus trace amounts of oxidized materials. Clay is not added in the CRR and thus there are no NAS mineral products formed there.

Off-gas from the CRR then flows to the Off-Gas Cooler (OGC), where it is rapidly cooled from $\sim 950^{\circ}$ Celsius to $\sim 160^{\circ}$ Celsius using a water spray. The off-gas then flows through the hightemperature filter where any residual solids are removed. It then passes through HEPA filters and process gas blowers prior to discharge to the atmosphere. The off-gas does not require scrubbers and consequently, no liquid secondary waste stream is created from the off-gas stream. The process off-gas is reported to be Maximum Achievable Control Technology (MACT) compliant at discharge, consisting almost entirely of water vapor, $\mathrm{CO}_{2}, \mathrm{~N}_{2}$, and $\mathrm{O}_{2}$.

Figure 2-11 depicts the off-gas system components anticipated for a FBSR system that could potentially be used to treat and immobilize Hanford LAW ${ }^{17}$.

\footnotetext{
${ }^{17}$ Note that RPP-RPT-46668, 2010, Supplemental Treatment Pre-Conceptual Engineering Revi ew, reports that an activated carbon bed may also be required in the off-gas train to meet Hanford emission requirements for Hg.
} 
Process and system off-gas streams are continuously monitored at three points. The first is just downstream of the PSF where the continuous process monitoring system (CPMS) monitors the filtered DMR process gas stream for $\mathrm{H}_{2}, \mathrm{O}_{2}, \mathrm{CO}, \mathrm{CO}_{2}$, total hydrocarbons, $\mathrm{NO}, \mathrm{NO}_{2}$, and total $\mathrm{NO}_{\mathrm{X}}$. The $\mathrm{H}_{2}$ concentration is a key parameter for operational control of the DMR (e.g., reducing environment in the DMR) and controlling carbon concentrations in the DMR bed. This is important to controlling $\mathrm{NO}_{\mathrm{x}}$ emissions. A second measurement point is downstream of the CRR to monitor $\mathrm{O}_{2}$ concentration in the exiting process gas to ensure oxidation of $\mathrm{CO}$ to $\mathrm{CO}_{2}$. The final measurement occurs at the stack where the continuous emissions monitoring system (CEMS) monitors for $\mathrm{O}_{2}, \mathrm{CO}, \mathrm{CO}_{2}$, total hydrocarbons, $\mathrm{NO}, \mathrm{NO}_{2}$, total $\mathrm{NO}_{\mathrm{x}}$, and $\mathrm{SO}_{2}$. A radiation monitor also monitors off-gas at the stack (RPP-RPT-46668, Rev 0).

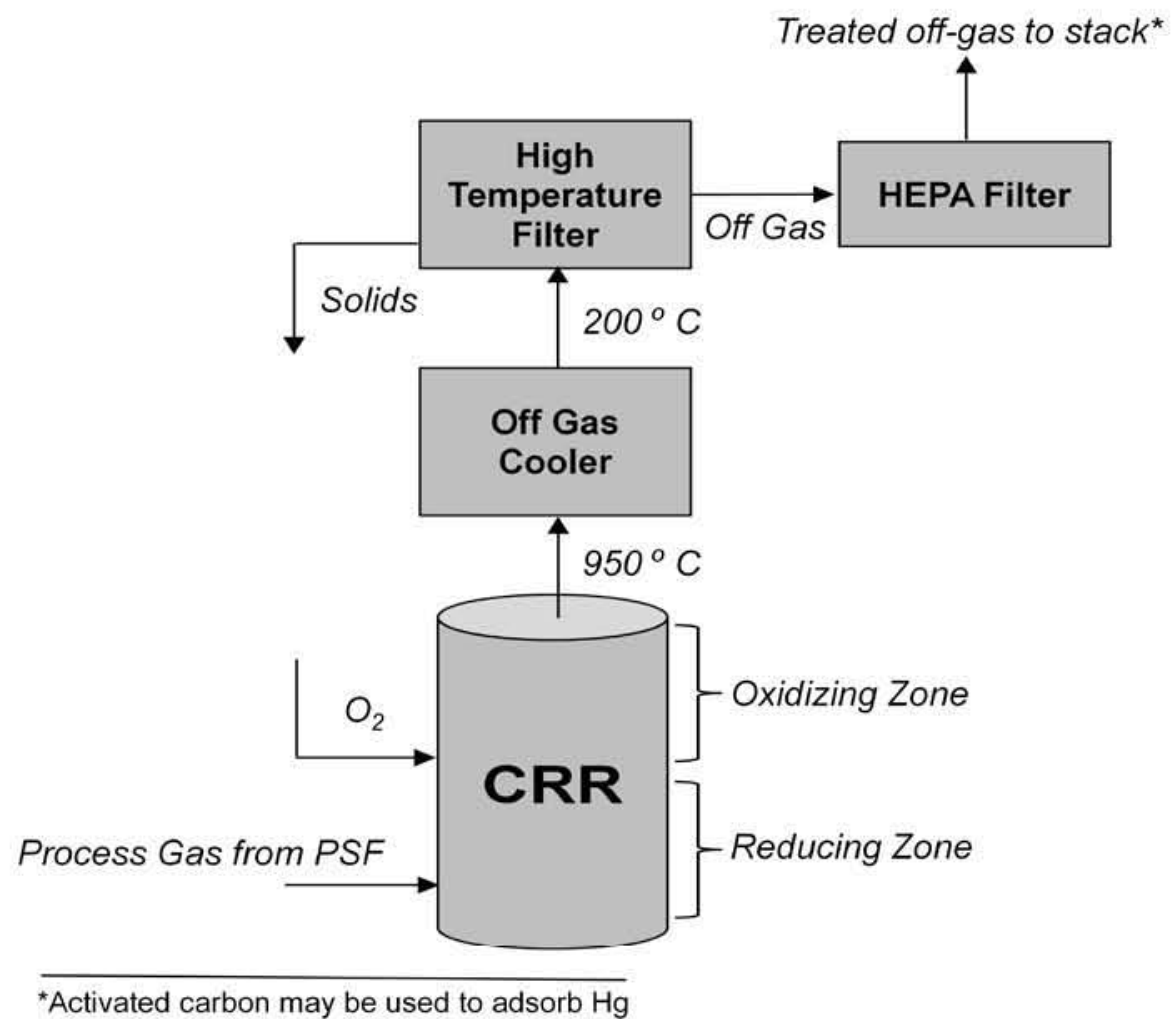

Figure 2-11. Nominal FBSR Process and Off-Gas Treatment

\subsubsection{Conversion to Monolith}

The Hanford IDF draft waste acceptance criteria (IDF 2004, CEES-0134, Rev. B, 2004, Integrated Disposal Facility Waste Acceptance Criteria) include minimum acceptable limits for leach resistance, compressive strength, void space, free liquids, dispersible fines, and waste loading ${ }^{18}$. The FBSR mineralized product appears to meet all known draft IDF disposal requirements except for compressive strength and dispersibility. Therefore, various binder

\footnotetext{
${ }^{18}$ The IDF waste acceptance criteria (WAC) have not been finalized. The IDF 2004 draft WAC (CEES-0134, Rev. $\mathrm{B}, 2004$ ) indicates a minimum compressive strength of $85 \mathrm{psi}$. The paper also includes a reference to a $1991 \mathrm{NRC}$ Staff Technical Position Paper (NRC 1991) that states that using minimum requirements is not recommended and $500 \mathrm{psi}$ should be reasonable for cement waste forms.
} 
materials are being evaluated to convert the granular and fines mineral product into a monolithic waste form.

As currently planned, the granular/fines product in the Product Receiver would be conveyed to a separate building or separate process area (Monolith/Packaging Plant) where the product would be blended with the binder materials in a pug-type mill and extruded into the bulk disposal containers (Figure 2-12). Once filled, the container would be closed, decontaminated, interimstored if/as required for binder curing, and then shipped to the IDF for disposal.

Hanford IDF analyses indicate that a compressive strength greater than 85 pounds per square inch (psi) is sufficient to protect against subsidence, i.e., settling and compaction of the waste and fill materials that could create surface depressions. Accordingly, if the FBSR mineralized waste form is selected for use at Hanford the granular and fines materials would be mixed with a binder to form a monolith with sufficient compressive strength to meet IDF requirements for disposal. Incorporating the mineralized product into a monolith also helps mitigate potential impacts associated with inadvertent human intrusion into the waste site by placing the contaminants in a less dispersible form. A monolith testing program was conducted by SRNL in accordance with the SRNL Quality Assurance Program under contract to TTT (RT-21-002). The

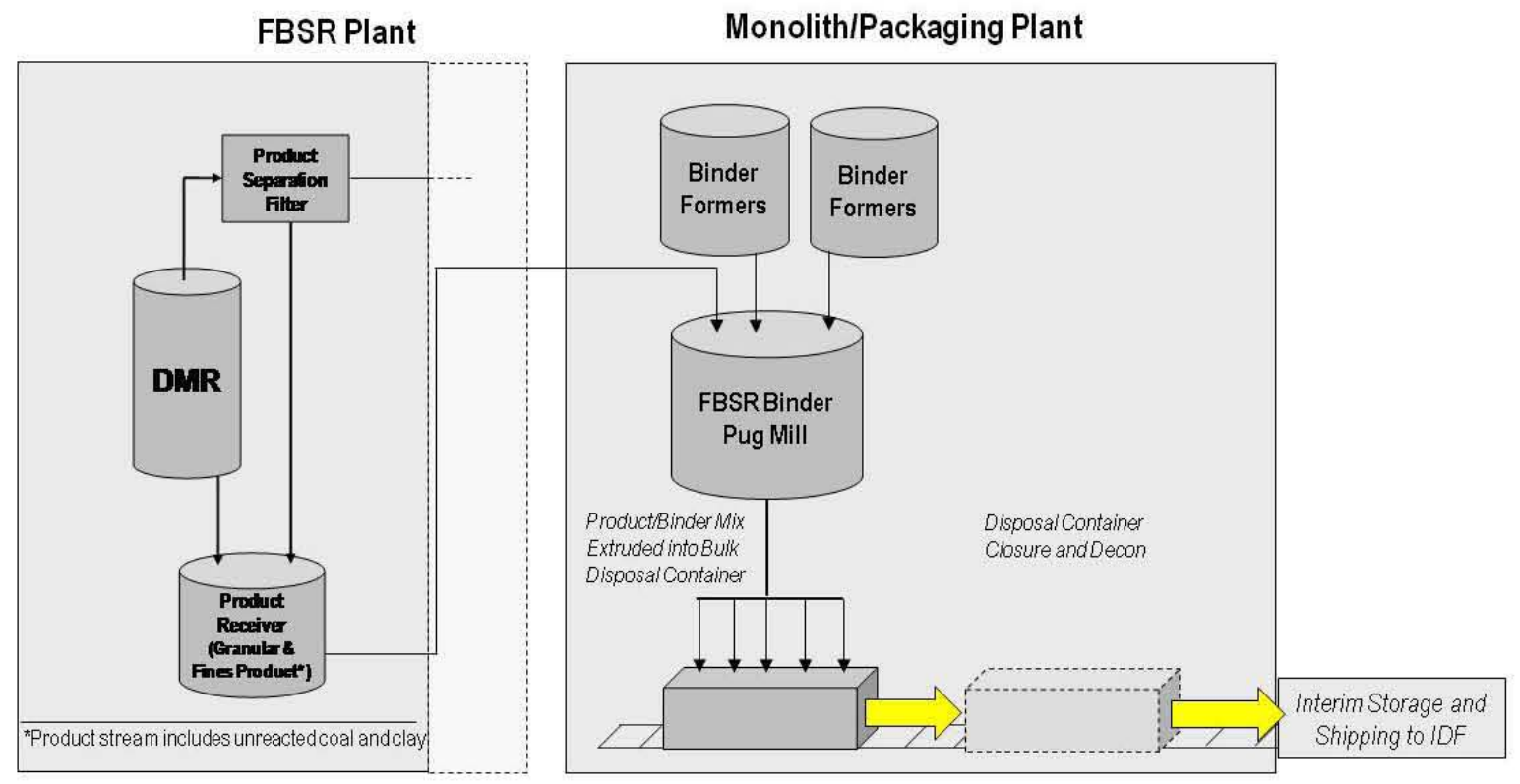

Figure 2-12. Depiction of Potential FBSR Product Conversion to Monolith

purpose was to:

- Determine acceptable binder material(s),

- Determine acceptable waste loadings of the mineral product in the monolith matrix, and

- Analyze monolith properties to ensure adherence to applicable requirements.

The Hazen Engineering Scale Technology Demonstration (ESTD) facility generated the NAS product used for the monolith tests using a Hanford LAW simulant. Five binder materials were selected for monolith testing: 
- Ordinary Portland Cement (OPC), a very common binder consisting mainly of calcium silicates,

- Ceramicrete (CER), a ceramic cement composed of magnesium oxide powder and soluble phosphate powder mixed with Class F fly ash,

- High alumina cements (FON), composed mainly of calcium aluminates rather than calcium silicates (creates lower $\mathrm{pH}$ pore water than $\mathrm{OPC}$ ),

- Geopolymers (GEO), which are amorphous to semi-crystalline, three-dimensional silicoaluminate materials; mineral polymers resulting from mixing clay or fly ash with $\mathrm{Na}$ silicate and/or $\mathrm{NaOH}$, and

- NuCap material, an advanced silicone geopolymer composite material developed by Global Matrechs, Inc.

It should be noted that conceptually the monolith might enhance the durability of the mineral waste form, however; that is not its intent. The intent is to enhance compressive strength and reduce dispersibility without impairing the mineral waste form. Several metals, including cadmium, antimony, and selenium, were added to the LAW and WTP secondary waste simulants. The metals were added at significantly higher levels than expected in actual LAW waste feed to enable successful measurement and their fate/performance determinations. Testing was conducted on 2-inch cubes and, for the better monolith performers, on cylindrical monoliths in two sizes (a photograph reproduced from RT-21-002 is presented in Figure 2-13); 3-inch diameter by 6 inches high, and 6 -inch diameter by 12 inches high.

The monoliths were tested for compressive strength per ASTM-C39/C39M-99, BET Surface Area for PCT analyses, PCT using ASTM 1285, elemental analyses, bulk density, and TCLP. The technical team evaluated all of the data presented above and concluded that, for monoliths tested to date, the formulation known as GEO-7 performed the best considering compressive strength and durability (TCLP and PCT). This is true for both the LAW and WTP SW simulant products. The normalized PCT release rates for $\mathrm{Cs}, \mathrm{Re}$, and I from the GEO-7 formulation were all below the desired value of $2.0 \mathrm{~g} / \mathrm{m}^{2}$ for $\mathrm{Na}$; and well below the LRM glass standard for $\mathrm{Na}$ $\left(0.27 \mathrm{~g} / \mathrm{m}^{2}\right)(\mathrm{RT}-21-002)$.

Continued monolith testing will be conducted during 2011 prior to the selection of a final binder formulation.

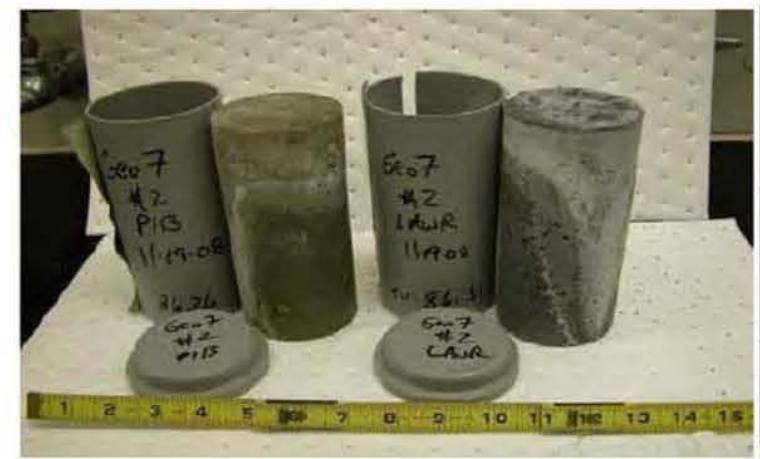

3 -in by 6 -in cylinders

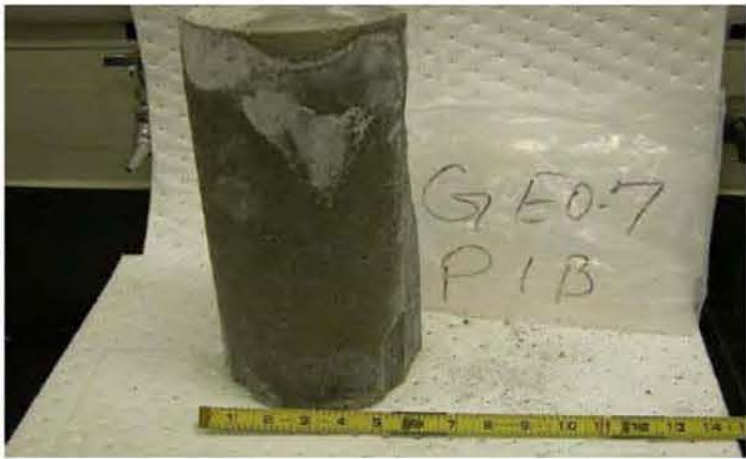

6-in by 12 -in cylinders

Figure 2-13. Photo of Cylindrical GEO-7 Monoliths Formed to Test FBSR Product 


\section{RPP-48903, Rev 0}

\subsection{FBSR HISTORY RELEVANT TO RADIOACTIVE WASTE TREATMENT}

Steam reforming has been used to pyrolyze radioactive wastes containing organics since the $1990 \mathrm{~s}$ in various types of reformers. These included drum-sized reformers and catalytic molten metal reformers, both of which operated in a batch mode, and later in fluidized bed reformers. The fluidized bed approach to steam reformation was a transformational technology, as it enabled the steam reforming treatment process of radioactive wastes to be carried out in a continuous process reformer rather than in separate batch reformer processes. Continuous operations typically enable higher throughput, lower costs, and reduced handling requirements. The remainder of this document focuses on the FBSR process developed by Studsvik, an international nuclear technical services company.

\subsection{PREVIOUS USES WITHIN THE DOE COMPLEX}

The FBSR process has been selected by DOE to treat tank wastes at INL and SRS.

Idaho National Laboratory - A Settlement Agreement (Grumbly 2005) between DOE and the State of Idaho signed in 1995 mandates treatment of approximately 1,000,000 gallons of Nabearing waste (SBW) at the INL by December 31, 2012. DOE evaluated potential treatment technologies over a several year period in order to identify a treatment technology that meets DOE and regulatory treatment requirements. Those studies, including the High-Level Waste and Facilities Disposition Environmental Impact Statement, resulted in the identification of five treatment alternatives as the most appropriate for the SBW. DOE selected steam reforming to treat the SBW in a 2005 ROD (70 FR 242, 2005, Record of Decision for the Idaho High-Level Waste and Facilities Disposition Final Environmental Impact Statement) and in 2006 DOE approved a performance baseline for the treatment of the INL SBW using FBSR (Garman 2006). In the ROD DOE stated that the preferred path for the SBW would be as remote-handled transuranic waste (RH-TRU) at the Waste Isolation Pilot Plant (WIPP) in Carlsbad, New Mexico, but that:

"Until such time as the regulatory approvals are obtained and a determination that the waste is TRU is made, the Department will manage the waste to allow disposal at WIPP or at a geologic repository for spent nuclear fuel (SNF) and HLW."

The FBSR process would be used to produce a carbonate waste form for disposal at WIPP. To mitigate the possible need for HLW geologic repository disposal, if disposal at WIPP cannot be attained, pilot plant tests were conducted to demonstrate the production of a leach-resistant, alkali, aluminosilicate, waste form (e.g., mineral waste form) using the FBSR process. Based on pilot testing, both waste forms were demonstrated to be feasible for production in the Integrated Waste Treatment Unit (IWTU) under construction at INL (Ryan 2008) which is depicted in the lower right corner of Figure 3-1. Cold commissioning of the IWTU is scheduled to start in 2011. Approximately 15 months will be required to process the one million gallons of SBW.

Savannah River Site - SRS Tank 48 is a 1.3 million gallon tank. The tank was isolated from the system and taken out of use in 1983 because of its contents. Tank 48 contains approximately 250,000 gallons of radioactive salt solution with significant quantities of organic tetraphenylborate (TPB), a material not compatible with the SRS Tank Farm operations. The TPB represents a flammability hazard and is not suitable for direct processing in the DWPF. 


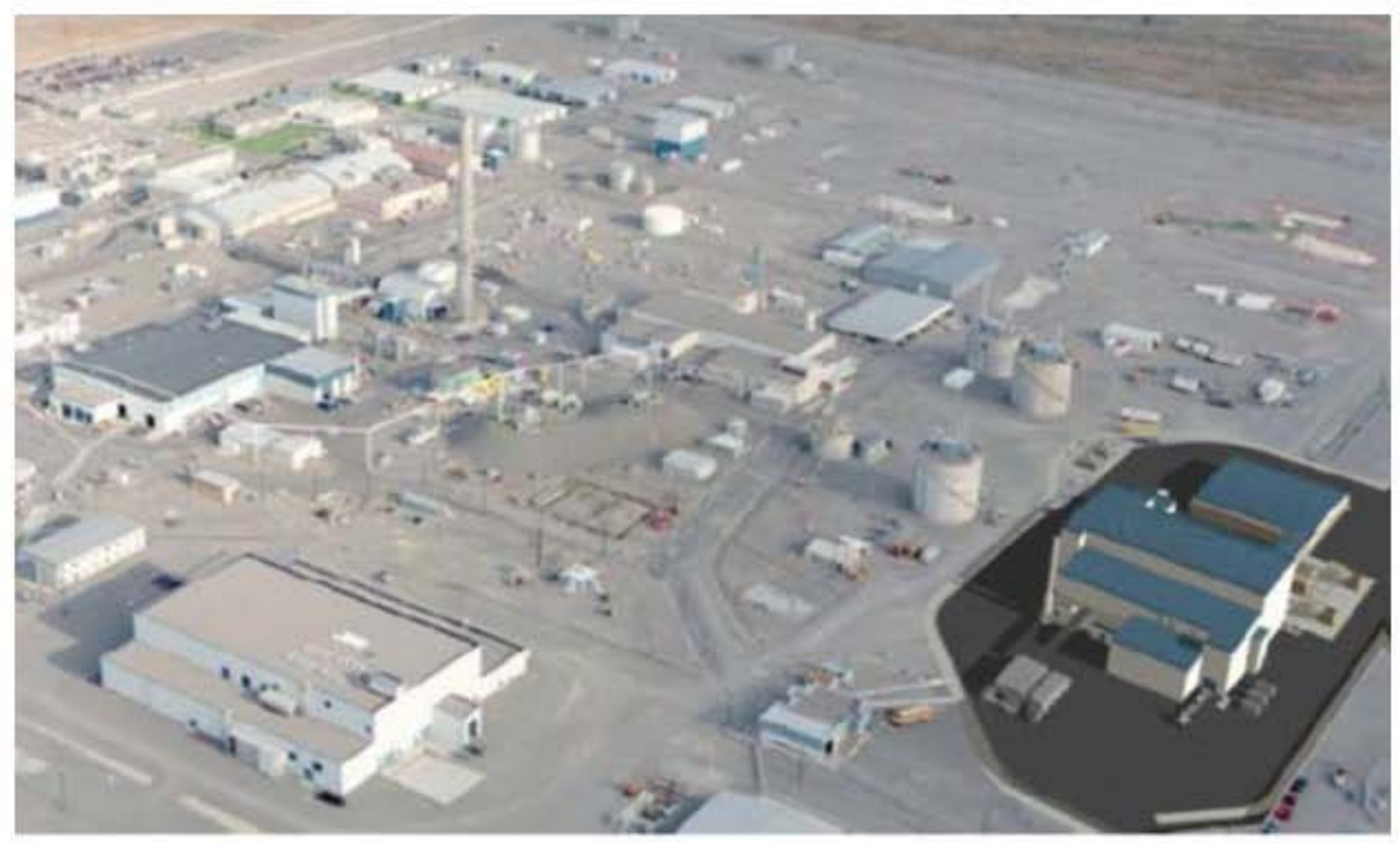

Figure 3-1. Depiction of Integrated Waste Treatment Unit at INL

The Washington Savannah River Company (WSRC) evaluated al ternatives to treat Tank 48 and selected two processes, Wet Air Oxidation (WAO) and FBSR as final candidates. In 2006 an Independent Technical Review Team (IRT) conducted an assessment of the WSRC proposed path forward and concluded that FBSR was the most mature candidate technology for Tank 48 wastes (LWO-SPT-2007-00249, Rev. 1, 2007, Technology Maturation Plan (TMP) Fluidized Bed Steam Reforming (FBSR) For Tank $48 H$ Treatment Project (TTP)) considering the advanced design work for FBSR remote operations currently in-progress for treatment of Na bearing tank wastes at INL.

DOE concurred with the SRR recommendation to proceed with the deployment of the FBSR technology to treat the contents of Tank 48H. SRNL developed and proved the concept with non-radioactive simulants for SRR beginning in 2003.

FBSR pilot scale testing with the Tank $48 \mathrm{H}$ simulant has demonstrated the ability to destroy greater than $98 \%$ of the nitrites and greater than $99.5 \%$ of the nitrates from the Tank $48 \mathrm{H}$ simulant, and to form a solid product that is primarily alkali carbonate. The alkali carbonate product would be dissolved, blended with other SRS tank waste, and transferred to the DWPF for vitrification (Williams 2010).

A Technology Readiness Assessment (TRA) was conducted (SPD-07-195, 2007, Savannah River Stite Tank 48H Waste Treatment Project Technology Readiness Assessment) using guidance contained in the Department of Defense (DoD), Technology Readiness Assessment Deskbook. The Fluidized Bed Steam Reformer System (TRL-4); and the Off-Gas Treatment System (TRL-4) was found to be sufficiently mature for that point in the project. The TRL 
rating is attributed to a combination of the commercial application of this technology at the Studsvik Facility at Erwin, Tennessee; the IWTU at the DOE Idaho Site; and engineering-scale tests using Tank $48 \mathrm{H}$ simulant by THORß Treatment Technologies at Hazen Research, Inc. facility. Lack of actual waste testing prevented these systems from achieving a TRL-5. SRS Tank $48 \mathrm{H}$ will use a unique "dry to wet" product handling system, which was found to be less mature (TRL-3) because the functionality and equipment requirements for that system had not been defined.

By 2008, several pilot scale campaigns had been completed and extensive crucible testing and bench scale testing were performed in the SRNL Shielded Cells using Tank $48 \mathrm{H}$ radioactive sample feed.

Hanford - The additional engineering design, pilot testing, and information learned from the selection of FBSR for INL SBW and SRS Tank 48 wastes has provided DOE with a substantially greater level of understanding of the FBSR technology than it had in 2002 when FBSR was one of the alternatives under consideration for LAW treatment and immobilization. Since that time further testing has been conducted using surrogate Hanford LAW and secondary wastes to better understand its potential application at Hanford. This is further discussed in Section 3.

DOE selected FBSR to treat the INL SBW and the SRS Tank 48 organic wastes in part because of the rigor of the testing and design processes. Its selection to treat those two chemically diverse waste streams attests to the versatility of the FBSR process to treat radioactive wastes with diverse chemical properties in a safe and effective manner.

The solid waste product produced during the FBSR process can be tailored to have the properties required to meet disposition pathway requirements. For example, the product produced at the Erwin, Tennessee facility is an ash-like powder that is suitable for disposal in high integrity containers (HIC) that have been approved by the NRC for use in licensed commercial LLW disposal sites. There are no waste form performance requirements for this material other than it must be class $\mathrm{C}$ or less and be contained in a High-Integrity Container. The waste form that will be produced in the IWTU at INL from the SBW will be carbonate waste form suitable for packaging in canisters for disposal in the WIPP salt repository in Carlsbad, New Mexico. In both of these cases, the final waste form is not relied upon as a barrier against radionuclide release. FBSR processing of the SRS Tank 48 high organic waste stream is used to destroy the organics. Because the treated waste will subsequently dissolved and blended with other tank wastes for treatment in the DWPF ${ }^{19}$, the SRS FBSR product will be intentionally soluble in water.

Accordingly, the waste forms produced by FBSR at Erwin, INL, and SRS are substantially different from the waste form required for Hanford LAW even though the basic equipment is similar. At Hanford, the FBSR process would need to be configured to produce a mineral waste form that is insoluble. The granular and fines materials produced by the FBSR process would also need to be converted into monolithic form to be suitable for on-site disposal in the IDF.

\footnotetext{
${ }^{19}$ The DWPF is the SRS HLW vitrification plant.
} 


\subsection{PREVIOUS USES WITHIN COMMERCIAL INDUSTR Y}

During the 1990 s, several commercial companies saw an opportunity to use thermal technologies to reduce the volume of spent resins from nuclear power plants prior to disposal and thereby reduce the very high cost of disposal. The technologies used for that purpose included vitrification (ATG Inc), incineration (SEG Inc), Molten Metal Catalytic ProcessingB) (Molten Metal Technologies Inc), and FBSR (Studsvik). Of those, only the Studsvik Processing Facility emerged as a continuing viable operation. GTS Duratek al so offered steam reforming services to treat certain radioactive wastes using a portable drum unit that operated on a batch basis.

In 1999 Studswik built a FBSR facility in Erwin, Tennessee using its THermal Organic Reduction $\left(T H O R^{3}\right.$ ) process to pyrolyze spent ${ }^{23}$ organic resins from commercial nuclear facilities. This was the first continuous radioactive waste steam reformer put into operation (Figure 3-2).

The Studswik plant treats radioactive waste such as spent ion exchange resins, activated charcoal, filter media, and sludge materials originating from commercial nuclear reactor operations. The company reports that it has treated wastes with radiation levels exceeding $400 \mathrm{R} /$ hour; which is several hundred times greater than the typical radiation levels anticipated to be associated with pretreated LAW.

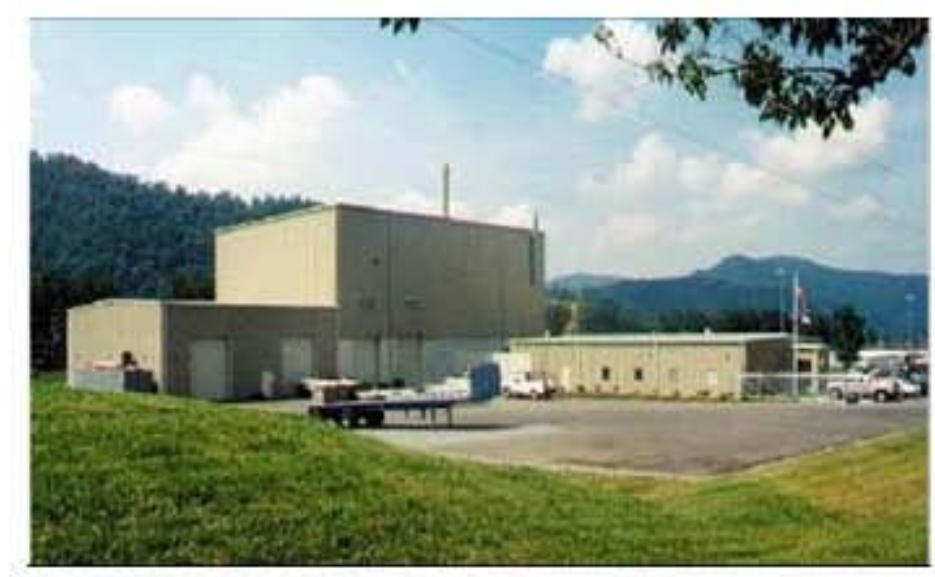

Figure 3-2. Commercial FBSR Resin/Sludge Treatment in Erwin, TN

\footnotetext{
${ }^{n 0}$ Spent resins in this context refer to ion ex change resins that were used to remove radionuclides (such as ${ }^{157} \mathrm{Cs}$ ) from primary coolant and from waste streams in com mercial nuclear power plants. When the resins become loaded with radionuclides a number of utilities chose to send the resins to disposal rather than regener ate (rem ove the radiomuclides from the resins). This is an economic choice that factors in the additional cost of regeneration and the need to neutralize, treat, and dispose of the regeneration wastes.
} 


\subsection{CURRENT STATE OF KNOWLEDGE FOR USING FBSR AT HANFORD}

To date, virtually all that is known about FBSR for treating Hanford LAW or liquid secondary wastes is based on tests conducted using surrogate Hanford wastes (Figure 4-1 reproduced from Jantzen 2010). This includes engineering scale tests conducted at:

- Hazen Research in 2001 in an auto-catalytically heated 6" single reformer,

- SAIC STAR Test Facility in 2003 and 2004 in an externally heated 6" single reformer, and

- Hazen Research in 2006 and 2008 in an auto-catalytically heated 15" dual reformer.

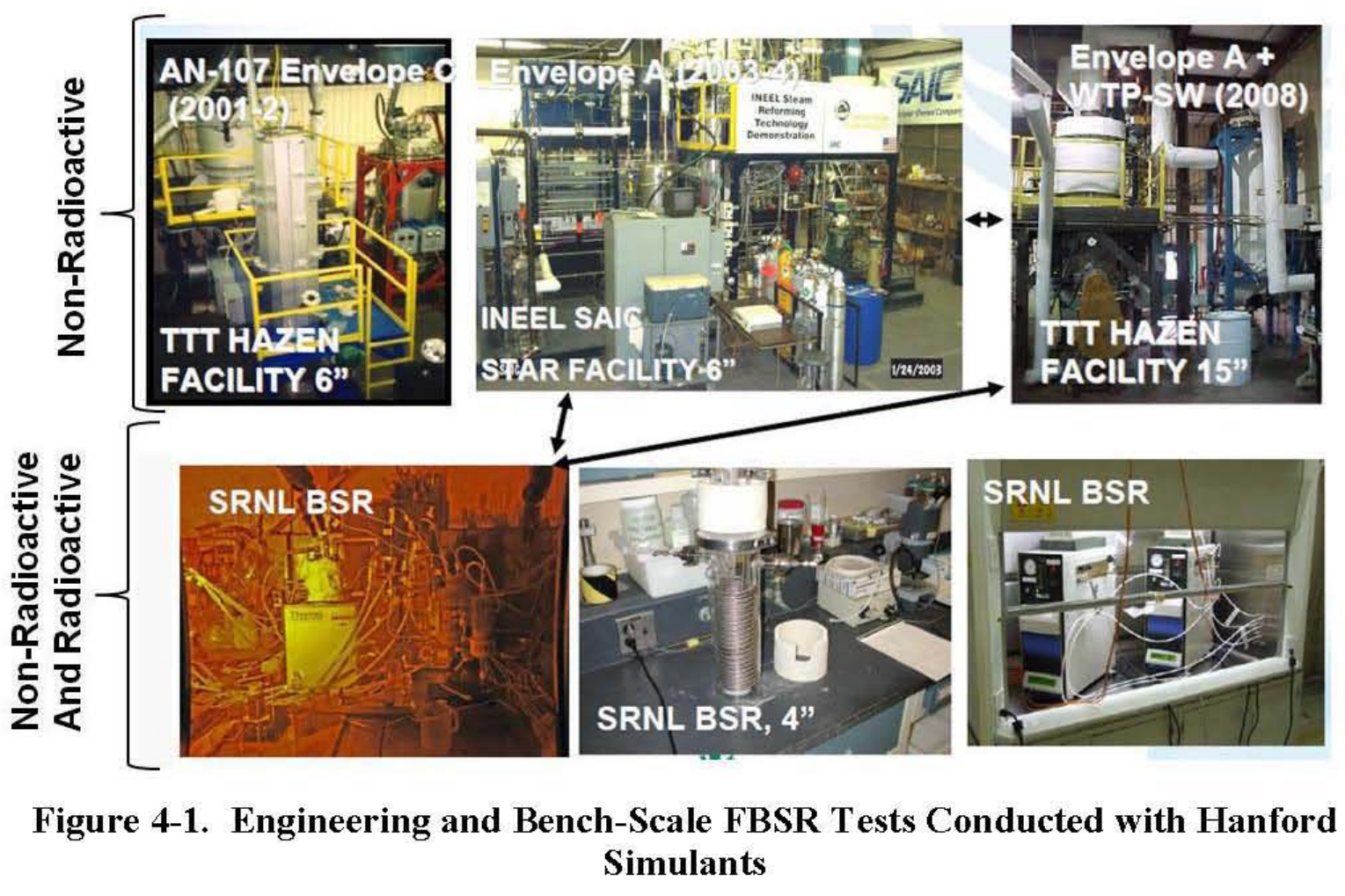

In addition Bench-Scale Reformer (BSR) testing has been conducted at SRNL in an externally heated single reformer and a combination unit in a shielded cell that is externally heated and auto-catalytically heated dual reformer.

The FBSR product (mineral and fines) has been tested using PCT (with and without coal removed), SPFT (with coal removed), and PUF (with coal removed). In FY2011 tests are being conducted using actual SRS and Hanford LAW derived from tank wastes stored in the 222-S Laboratory at Hanford and sent to SRNL for hot BSR treatment. The BSR product will be tested using a combination of PCT, SPFT, and PUF test protocols by SRNL and PNNL. The tests will be conducted on the mineral product (granular and fines) as well as the mineral product converted to a monolith form. These tests will provide DOE with information required to determine the long-term durability of the FBSR waste form. Data from those tests will be used by scientists to develop numerical parameter values for use in the kinetic release rate model. The 
same release rate model that is used in performance assessments to predict radionuclide releases from glass waste forms.

Some scientists (McGrail and Pierce at PNNL; Jantzen at SRNL) have predicted that certain radionuclides and other waste constituents may be captured within sodalite crystal cages as the mineral is formed in the DMR. If that were to be the case, it could make ${ }^{99} \mathrm{Tc}$ and ${ }^{129} \mathrm{I}$ less susceptible to release from the mineral waste form. These predictions are in part based on minerals science and in part based on non-congruent leaching behavior occurring in independent testing at PNNL and SRNL.

The basic process leading to mineral formation is based on clay losing hydroxyls at the nanoscale while at DMR operating temperatures (Figure 4-2 reproduced from Jantzen 2010). Alkali from the waste causes the destabilized clay to form nepheline and sodalite minerals.

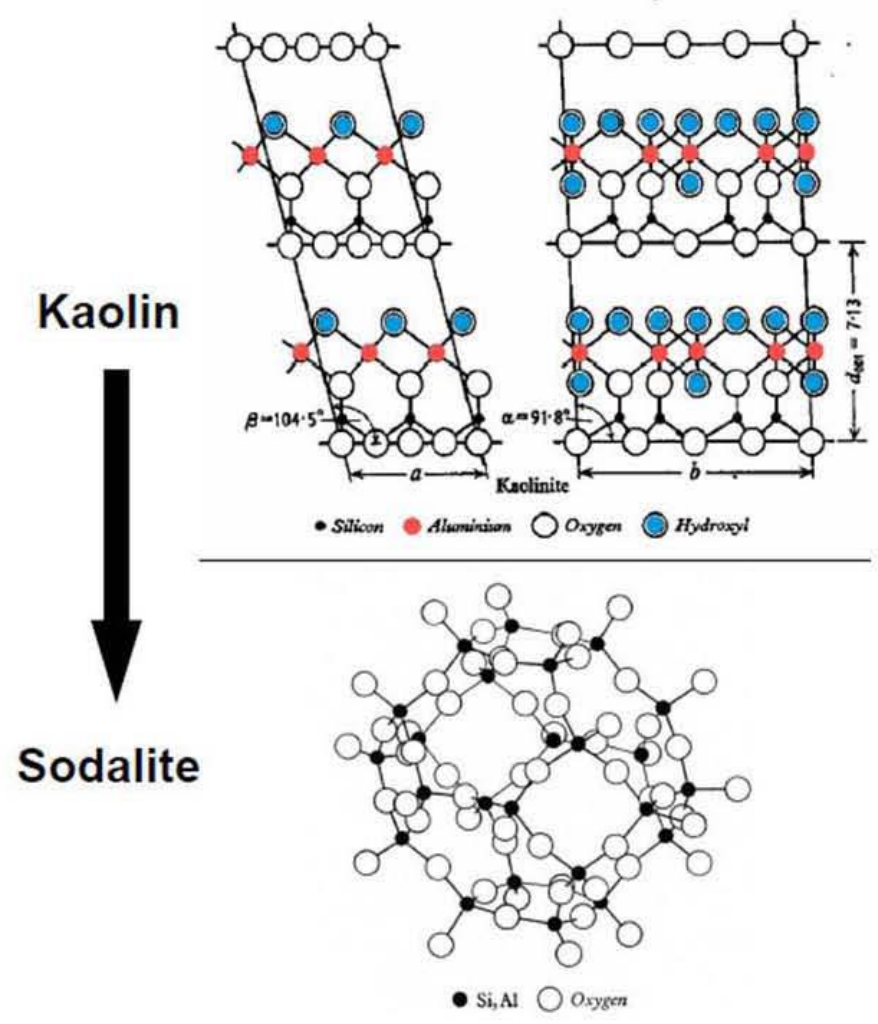

Figure 4-2. Formation of Sodalite from Kaolin Clay during FBSR

The sodalite minerals contain cage-like structures that have the ability to form around sulfates, halides $(\mathrm{Cl}, \mathrm{I}, \mathrm{F})$ and pertechnetate $\left(\mathrm{TcO}_{4}{ }^{-}\right)$. The non-congruent dissolution of the FBSR minerals formed from surrogate wastes suggest that Re is within a sodalite cage. 
Mattigod synthesized a sodalite mineral with $\operatorname{Re}(\mathrm{VII})$ that is depicted in Figure 4-3 (reproduced from PNNL-SA38162,2006 , Synthesis and Structure of Perrhenate Sodalite). Figure 44 dem onstrates the capture of Re by a sodalite. $\mathrm{Re}(\mathrm{VII})$ has an ionic radius of 52 picometers $^{21} \cdot \mathrm{Tc}(\mathrm{VII})$ has a similar ionic radius, i.e., 51 picometers while $\mathrm{Tc}(\mathrm{TV})$ is approximately $50 \%$ larger with an ionic radius of 78.5 picometers ${ }^{22}$. Accordingly, a key question is the oxidation state that the technetium is in when the sodalite is formed during the

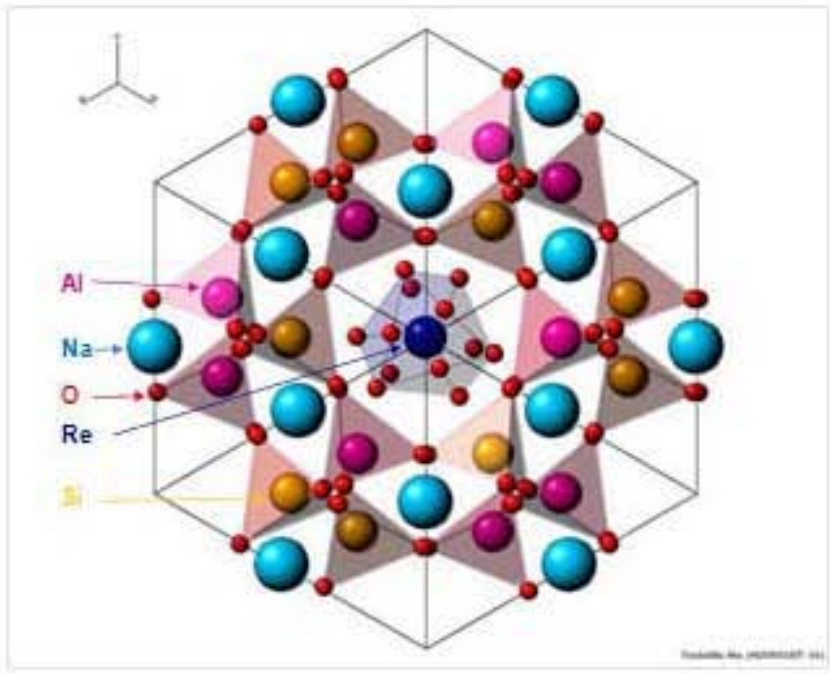

Figure 4-3. Depiction of Rhenium Bonded within the Crystal Lattice of a Single Sodalite Cell FBSR process.

While the Hanford LAW samples that will be used in the FY2011 BSR runs at SRNL contain ${ }^{92} \mathrm{Tc}$ from the Hanford tanks, the surrogate will al so be doped with Re to develop correlations between Re behavior in surrogate LAW and Tc-99 behavior in actual LAW from Hanford tanks. As depicted in Figure 4.4, conducting the BSR tests with actual tank waste provides critical information that is necessary to vali date data obtained through FBSR runs using surrogate LAW waste feeds. The BSR runs with Hanford tank waste LAW during 2011 will aid in buil ding correlations with Hanford surrogate LAW waste tests run at the BSR and engineering scales.

To better understand the location of ${ }^{97} \mathrm{Tc}$ in the FBSR mineral product, DOE plans to conduct a series of $\mathrm{X}$-ray absorption spectroscopy analyses on samples produced from actual Hanford tank waste from the BSR runs being conducted at SRNL during FY2011. Although X-ray

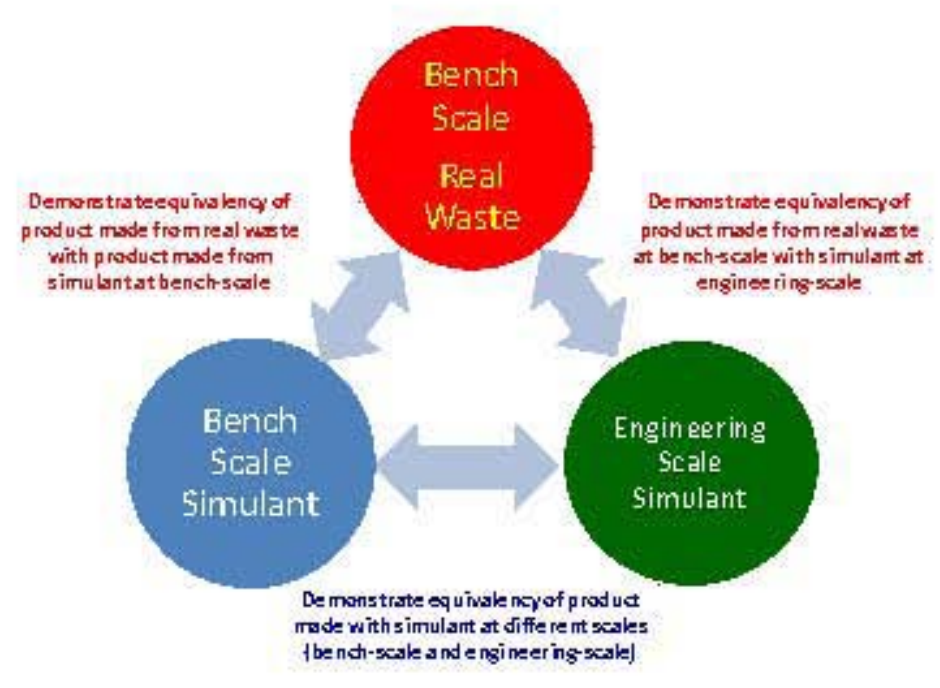

Figure 4-4. T esting with Actual Hanford Tank Waste Provides Important Correlations Necessary to Validate Results Obtained with Surrogate Waste Tests

\footnotetext{
21 "WebElements: the periodic table on the web", http://www webelem ents. com/thenium/atom_sizes.htm1.

2 "WebElements: the periodic table on the web", http//www webelem ents. com/technetium/atom_sizes.htm1.
} 
absorption spectroscopy (XAS) will be used as a primary technique to determine Re and ${ }^{99} \mathrm{Tc}$ speciation, a set of secondary analysis techniques will also be used. These include Scanning Electron Microscopy with Energy-Dispersive Spectrometry (SEM-EDS), Transmission Electron Microscopy with Energy-Dispersive Spectrometry (TEM EDS), and if necessary, Micro X-ray Defraction ( $\mu \mathrm{XRD}), \mathrm{X}$-ray Photoelectron Spectroscopy (XPS), and electron microprobe. These analyses will aide in understanding how ${ }^{99} \mathrm{Tc}$ and ${ }^{129} \mathrm{I}$ behave during the FBSR process.

The long-term fate of ${ }^{99} \mathrm{Tc}$ and ${ }^{129} \mathrm{I}$ in Hanford LAW are of principal interest to DOE, its regulators, and stakeholders. Both of those radionuclides have very long radioactive half-lives, are mobile in groundwater, and have low regulatory limits. While there are other radionuclides in LAW at higher curie concentrations such as ${ }^{137} \mathrm{Cs}$, factors such as short radioactive half-lives or relative immobility in groundwater result in substantially lower calculated risks for such nuclides and, therefore, lower levels of concern.

Since 2001, a progressive series of bench, engineering, and pilot-scale FBSR tests have been conducted with Hanford LAW surrogate wastes at the SRNL; at the Science and Technology Applications Research (STAR) Center in Idaho Falls, ID; and at Hazen Research in Golden, CO. The mineralized waste forms produced have been analyzed by PNNL and by SRNL, and identified as a mixture of various NAS minerals including nepheline and sodalites such as nosean.

The mineralized waste form produced during the FBSR process generally consists of both granular materials and fines, both of which are reported by various researchers (e.g., WSRC-TR2005-00102, 2005, Durability Testing of Fluidized Bed Steam Reformer (FBSR) Waste Forms for High Sodium Wastes at Hanford and Idaho; Jantzen 2006a) to exhibit the same durability characteristics. The durability tests used for the FBSR waste form are, for the most part, the same tests that are used to test the durability of Hanford LAW glass formulations as discussed in Chapter 1. The findings from the tests as reported in numerous scientific journal articles, technical symposia papers, and technical reports consistently indicate two key results as follows:

1. Greater than 99.99 percent of the ${ }^{99} \mathrm{Tc}$ - and ${ }^{137} \mathrm{Cs}$-are reported to be captured in the mineralized FBSR product ${ }^{23}$, and

2. The durability of the mineralized product, within the uncertainties inherent in glass and FBSR testing/measurements, appears to be of the same order of magnitude as indicated by LAW glass tests.

Questions remain with respect to leaching mechanisms that can release the radionuclides of interest. Studies of vitrified waste forms indicate that radioisotopes, such as ${ }^{99} \mathrm{Tc}$ and ${ }^{129} \mathrm{I}$ are released congruently (at the same time) as sodium is released from the waste form matrix. In the case of the FBSR mineralized waste form, it is reported that the dissolution is incongruent which means that sodium would leach from the waste form prior to constituents such as ${ }^{99} \mathrm{Tc}$ and ${ }^{129} \mathrm{I}$. This will be evaluated during upcoming tests with actual Hanford LAW (DOE/ER/14547-1).

Appendix A summarizes key FBSR and FBSR mineral waste form testing that has been conducted over the past several years.

Minerals Formed during the FBSR Process - The minerals formed during the FBSR process depend upon the constituents in the waste feed and the clay additives to the process. Because of

\footnotetext{
${ }^{23}$ Note that nonradioactive rhenium and cesium are used in place of the radionuclides ${ }^{99} \mathrm{Tc}$ and ${ }^{137} \mathrm{Cs}$, respectively.
} 
the variability of Hanford LAW waste feed chemistry (due to the multiple reprocessing and isotope recovery technologies used); the percentages of each mineral type formed from FBSR campaign to campaign can vary.

In general, the principal mineral s form ed have been determined to be the following in order of abundance (WSRC-STI-2008-00268):

- $\mathrm{NaAlSiO}_{4}$ - nepheline (feldspathoid mineral),

- $\left[\mathrm{NaAlSiO}_{4}\right]_{6} \mathrm{Na}_{2} \mathrm{SO}_{4}$ - nosean/sodalite (feldspathoid mineral),

- $\mathrm{A}_{2} \mathrm{O}_{3}$-corundum (startup bed material),

- $\mathrm{Fe}_{2} \mathrm{O}_{3}$ - hematite (sp inel mineral), and

- $\mathrm{Fe}_{3} \mathrm{O}_{4}$ - magnetite (spinel mineral).

Which specific minerals are produced during the FBSR process is influenced by the constituents present in the waste feed that are captured within the NAS structures to form minerals.

For example, the sodalite family of minerals has cage structures that can accommodate Cl, F, I, $\mathrm{SO}_{4}$ or $\mathrm{S}, \mathrm{B}, \mathrm{Mo}, \mathrm{Re}, \mathrm{Tc}, \mathrm{Be}, \mathrm{Zn}, \mathrm{Mn}$, and $\mathrm{P}$ ani ons. From XRD pattems it has been determined that simulants containing high $\mathrm{Cl}$ and $\mathrm{F}$ concentrations (such as found in LAW melter secondary wastes) produce sodalite.

$\mathrm{High} \mathrm{SO}_{4}$ simulants produce nosean. SRNL developed a process control strategy (MINCALC ${ }^{\mathrm{IM}}$ ) to estimate the mole percent and weight $\%$ of each mineral phase in the FBSR product (Jantzen 2010). The influence of the anions present on the mineral form produced is illustrated in Figure 4-5 (reproduced from Jantzen 2010) for LAW secondary waste simulant and a 68 -tank blend of LAW waste simulant converted into mineralized waste forms using the FBSR process. The simulant for secondary waste has high $\mathrm{Cl}$ and $\mathrm{F}$ concentrations ${ }^{24}$ and produces a high sodalite mineral phase while the 68 -
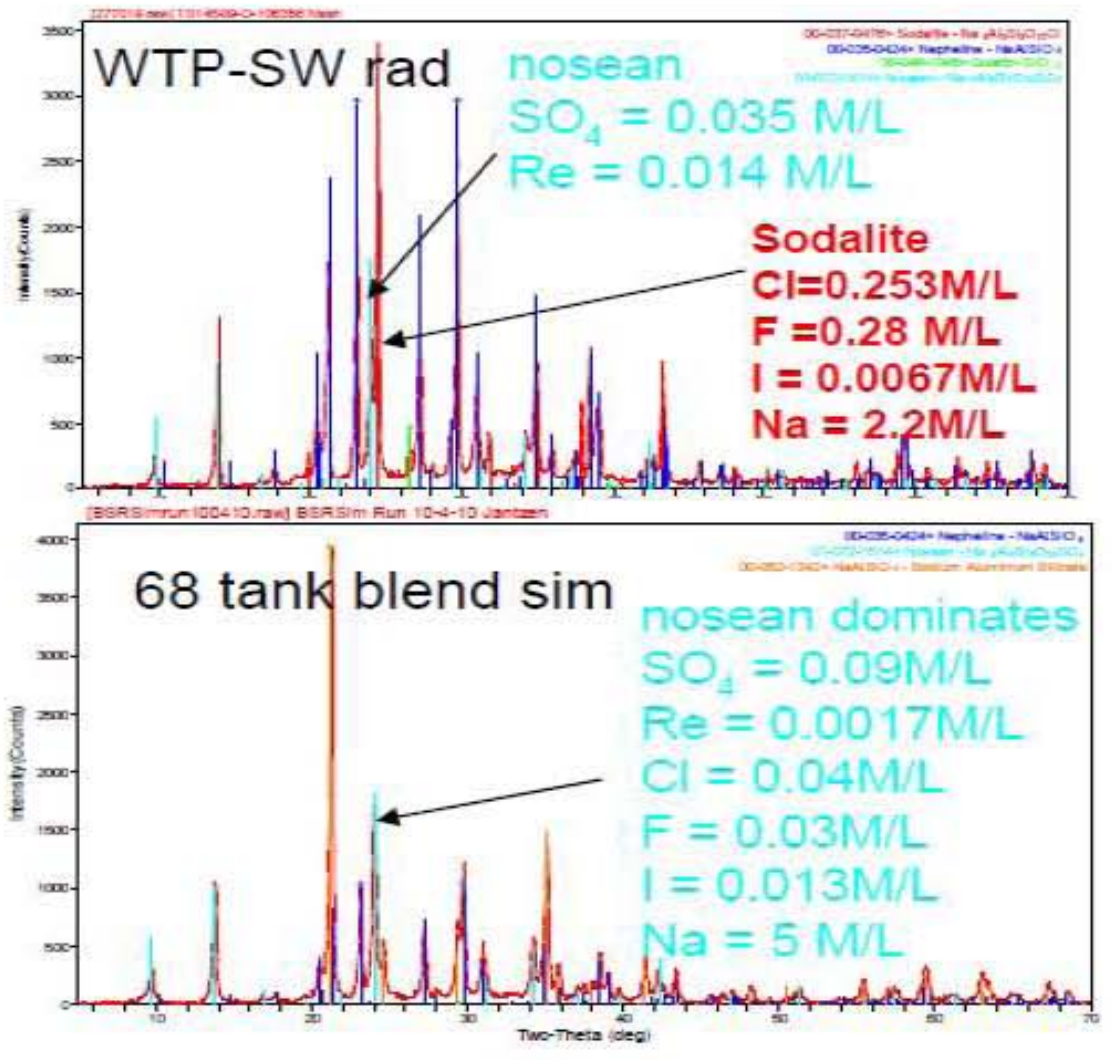

Figure 4-5. Relationship Between Anions in Waste Feed and Mineral Phases Formed during FBSR Processing

\footnotetext{
${ }^{24} \mathrm{The}$ high $\mathrm{Cl}$ and $\mathrm{F}$ in the surr ogate mimicking the recycle from the WTP LAW melter off-gas is attributable to the high volatility of those anions at melter temperatures and the buildup of those anions due to LAW melter submerged bed scrubber recycle.
} 
tank LAW blend, which is richer in $\mathrm{SO}_{4}$, produces a higher nosean mineral phase.

As illustrated in Table 4-1(reproduced from WSRC-STI-2008-00268, mineral phases formed using FBSR to immobilize wastes are similar to mineral phases produced in processes to create high temperature HLW ceramic waste forms and in Argonne National Laboratory testing to produce glass bonded sodalite ceramic waste forms.

\begin{tabular}{|c|c|}
\hline Mineral Phases Identified by TTT [34] & Mineral Phases Identified by SRNL[34] \\
\hline \multicolumn{2}{|l|}{ Feldspathoid Minerals } \\
\hline$\left[\mathrm{NaAlSiO}_{4}\right]_{6} \mathrm{Na}_{2}\left(\mathrm{SO}_{4}\right)$ (Nosean-Sodalite) & {$\left[\mathrm{NaAlSiO}_{4}\right]_{6} \mathrm{Na}_{2}\left(\mathrm{SO}_{4}\right)$ (Nosean-Sodalite) } \\
\hline $\mathrm{NaAlSiO}_{4}$ (Nepheline) & $\mathrm{NaAlSiO}_{4}$ (Nepheline) \\
\hline \multicolumn{2}{|l|}{ Spinel Minerals } \\
\hline \multirow[t]{2}{*}{$\mathrm{Fe}_{2} \mathrm{O}_{3}$ (Hematite) } & $\mathrm{Fe}_{2} \mathrm{O}_{3}$ (Hematite) \\
\hline & $\mathrm{Fe}_{3} \mathrm{O}_{4}$ (Magnetite) \\
\hline \multicolumn{2}{|l|}{ Startup Bed Material } \\
\hline $\mathrm{Al}_{2} \mathrm{O}_{3}$ (Corundum) & $\mathrm{Al}_{2} \mathrm{O}_{3}$ (Corundum) \\
\hline
\end{tabular}

The sodalite structure is flexible and allows monovalent species such as $\mathrm{Cs}^{+}, \mathrm{K}^{+}$, and others to substitute for $\mathrm{Na}^{+}$while anions ${ }^{25}$ can substitute for the $\mathrm{Cl}^{-}$atoms in the sodalite structure. In addition, $\mathrm{I}^{-}, \mathrm{Br}^{-}, \mathrm{OH}^{-}$, and $\mathrm{NO}_{3}{ }^{-2}$ can all substitute for the $\mathrm{Cl}^{-}$atoms in the sodalite structure. Boron and beryllium can substitute for $\mathrm{Al}$ in tetrahedral polyhedra in the sodalite structures as can titanium while elements like iron and zinc substitute for $\mathrm{Na}^{+}$. All bonding in the sodalite/nosean single unit cell is ionic and the atoms are regularly arranged. This is similar to the manner of ionic bonding in glass, but more highly ordered than the atomic arrangements in glass. For example, the $\mathrm{Na}$ atoms in sodalite are tetrahedrally coordinated and bound ionically to one $\mathrm{Cl}^{-}$(or substitutes) and bound ionically to three non-bridging oxygens from the framework $\left(\mathrm{AlO}_{4}\right)^{-5}$ and $\left(\mathrm{SiO}_{4}\right)^{-4}$. In glass, $\mathrm{Na}$ atoms are loosely bound in cavities between the framework $\left(\mathrm{AlO}_{4}\right)^{-5}$ and $\left(\mathrm{SiO}_{4}\right)^{-4}$ and loosely surrounded by ten or twelve oxygen atoms.

Many of the same alkali and alkaline earth substitutions that occur in sodalite can occur in the eight and nine coordinated ring sites in nepheline. The ring structures in nepheline are similar to the ring structures in the sodalites that define the cage structures in the sodalites. Nepheline can be a host mineral for other alkali or alkaline earth elements $\left(\mathrm{Cs}, \mathrm{K}, \mathrm{Ca}_{0.5}\right)$ substituting for $\mathrm{Na}^{+}$, while rare earth elements substitute for $\mathrm{Al}^{3+}$. Iron, $\mathrm{Ti}^{3+}, \mathrm{Mn}, \mathrm{Mg}, \mathrm{Ba}, \mathrm{Li}, \mathrm{Rb}, \mathrm{Sr}, \mathrm{Zr}, \mathrm{Ga}, \mathrm{Cu}, \mathrm{V}$, and $\mathrm{Yb}$ can all substitute in the nepheline lattice. In addition, $\mathrm{BaAl}_{2} \mathrm{O}_{4}, \mathrm{SrAl}_{2} \mathrm{O}_{4},(\mathrm{Sr}, \mathrm{Ba}) \mathrm{Al}_{2} \mathrm{O}_{4}$, $\mathrm{RbAlSiO}_{4}, \mathrm{Cs} \mathrm{AlSiO}_{4}$, and $\mathrm{KFeSiO}_{4}$ all have nepheline/kalsilite structures with similar ring structures (WHC-SD-WM-TI-699, Rev 2, 1996, Technical Basis for Classification of LowActivity Waste Fraction from Hanford Site Tanks).

The spinels readily accommodate many of the transition metals that are hazardous under RCRA. For example, under the reducing conditions in the DMR species such as chromium will be reduced to $\mathrm{Cr}^{+3}$, which will be sequestered within the structure of a spinel as the mineral phases

\footnotetext{
${ }^{25}$ For example, $\left(\mathrm{SO}_{4}\right)^{-2},\left(\mathrm{MoO}_{4}\right)^{-2},\left(\mathrm{AsO}_{4}\right)^{-2},\left(\mathrm{MnO}_{4}\right)^{-1},\left(\mathrm{ReO}_{4}\right)^{-1}$, and presumably [to be evaluated in 2011$]\left(\mathrm{TcO}_{4}\right)^{-1}$
} 


\section{RPP-48903, Rev 0}

form. The spinel group of minerals contains over twenty members, only a few of which are considered common. Spinels have very similar structures. The general formula of the Spinel Group is $\mathbf{A B}_{2} \mathbf{O}_{4}$. The "A" represents a divalent metal ion such as magnesium $(\mathrm{Mg})$, iron (Fe), nickel (Ni), manganese $(\mathrm{Mn})$, and/or zinc $(\mathrm{Zn})$. The " $\mathrm{B}$ " represents trivalent metal ions such as $\mathrm{Al}, \mathrm{Fe}$, chromium $(\mathrm{Cr})$ and/or (manganese) Mn. Note that titanium $\left(\mathrm{Ti}^{+4}\right)$ and lead $\left(\mathrm{Pb}^{+2}\right)$ may also occupy this site. Solid solutioning is common in this group of minerals meaning that they may contain certain percentages of different ions in any particular specimen (The Spinel Group of Minerals, Amethyst Galleries, Inc., 2010).

Other Constituents in the FBSR Product- The primary objective of using the FBSR process to treat Hanford LAW (or secondary waste) is to drive the FBSR reactions in the DMR to form minerals that will sequester the various radioactive and hazardous materials in the waste feed. Coal is added to the process to create the required reducing environment, create the required heat for the process to proceed, and convert organics to $\mathrm{CO}_{2}$ and water (steam). Clay is added to the process to react with the various metals and radionuclides to form the mineralized product.

Excess amounts of both coal and clay are added relative to how much should be required to exactly meet the chemical reaction stoichiometry ${ }^{26}$ requirements for the reactions in the DMR. This is done in order to drive the chemical reactions to the desired endpoints (destruction of organics and conversion of waste into minerals) and ensure that all of the waste feed reacts. The fact that excess coal and clay are present in the product materials is a planned outcome. Excess kaolin clay in the product stream is not anticipated to have an impact on the performance of the waste form and may contribute to Al buffering (positive impact). Whether or not excess coal will be removed from the product is yet to be determined.

\subsection{HOW FBSR MIGHT FIT INTO HANFORD FLOW SHEET}

As previously shown in Figure 1-1 and discussed in Section 1, the Hanford flow sheet requires supplemental LAW treatment and immobilization to provide sufficient overall LAW treatment capacity to enable the WTP HLW processes to run at design throughputs. Regardless of whether that supplemental LAW treatment is met by FBSR, a Second WTP-type LAW vitrification plant, Bulk Vitrification, or Cast Stone; the throughput requirements would be the same.

RPP-CALC-48104, 200-Area Supplemental Treatment and Immobilization System Capacity, indicates the supplemental LAW production capacity required in order to meet a Hanford LAW process completion date by 2042 . The net production capacity is $2,600 \mathrm{MT} \mathrm{Na} /$ year. Assuming a $70 \%$ Total Operating Efficiency (TOE), the design production capacity is $3700 \mathrm{MT} \mathrm{Na} /$ year.

The feed to the FBSR plant would first be pretreated as discussed in Section 1. It is assumed that the feed will be provided from both the existing WTP Pretreatment Plant and from a supplemental pretreatment system located in the tank farms. Assuming the FBSR system will be designed on a modular basis, the FBSR units could be all co-located, or some units could be located in the 200-West Area and some in the 200-East Area. That type of arrangement could

${ }^{26}$ Stoichiometry refers to the quantitative relationships that exist between the reactants and products in chemical reactions. In a balanced chemical reaction, the relations among quantities of reactants and products typically form a ratio of whole numbers. For example, in a reaction that forms ammonia $\left(\mathrm{NH}_{3}\right)$, exactly one molecule of nitrogen $\left(\mathrm{N}_{2}\right)$ reacts with three molecules of hydrogen $\left(\mathrm{H}_{2}\right)$ to produce two molecules of $\mathrm{NH}_{3}$ in the following chemical reaction: $\mathrm{N}_{2}+3 \mathrm{H}_{2} \rightarrow 2 \mathrm{NH}_{3}$. 
help in treating LAW from tanks in the 200-West Area occur several years sooner as it would not require the LAW to be pumped cross-site during the early years of WTP operations when the 200-East Area DSTs would have inadequate free space to handle west to east transfers. If DOE elected to provide FBSR treatment in the 200-West Area, it would be reliant upon tank farmbased pretreatment of the LAW, also located in the 200-West Area.

\subsection{TECHNOLOGY MATURITY}

The Technology Readiness Level (TRL) for FBSR is reported in RPP-RPT-48092, Supplemental Treatment Program Technology Readiness Assessment. The TRL assessment methodology assesses the technical maturity of a technology for its application in the real world. The TRL is rated on a scale of 1 to 9 , where 1 represents a technology in the initial stages of basic research and 9 is the technology that has achieved a full production operating status. Figure -6 (reproduced from RPP-RPT-48092, Rev 0, 2010, Supplemental Treatment Program Technology Readiness Assessment) depicts the relationship between the TRL rating scale and DOE's Critical Decision (CD) project review process.

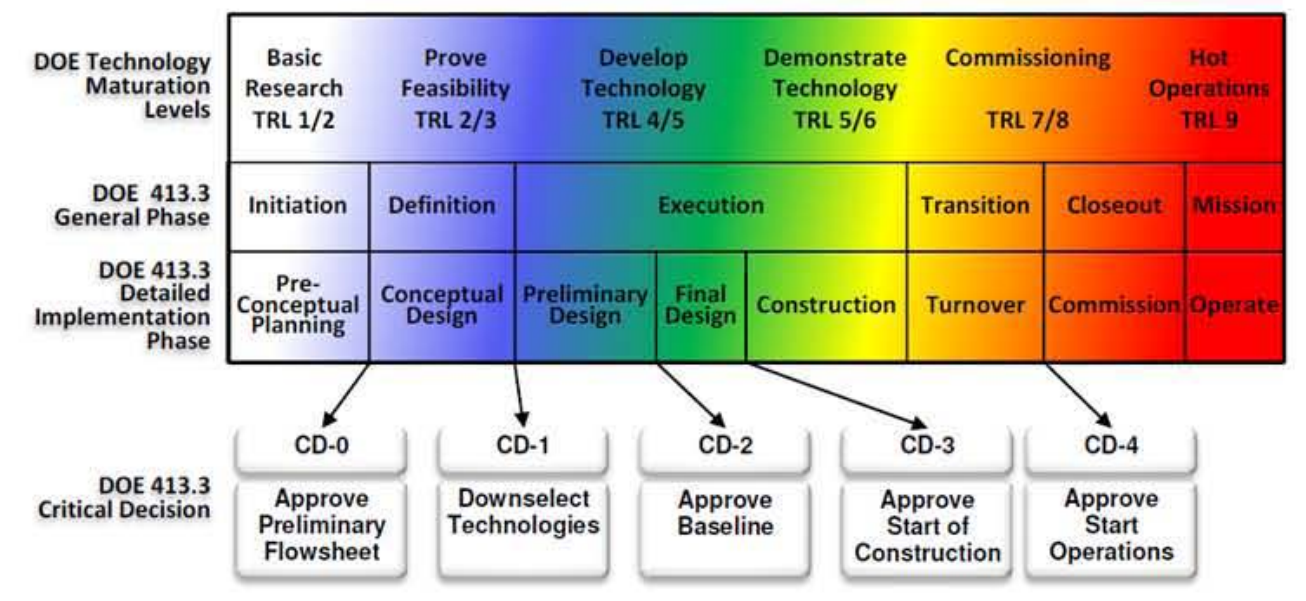

\section{Figure 4-6. Integrated Summary Schedule for Technology Readiness Level and Critical Decision Process}

The FBSR system was divided into three Critical Technology Elements (CTEs) for the purpose of reviewing the technology on a system-wide basis; the Reformer subsystem, the off-gas treatment system, and the monolithing subsystem. The TRL for FBSR was evaluated and assigned TRL4, which is a "Development Technology" as defined by Figure 4-6. Table 4-2 (reproduced from RPP-RPT-48092, Rev 0) shows a summary of the TRL rating developed for each CTE. Note that the CTE for monolithing subsystem had a TRL3 since monolithing may be first used at Hanford if FBSR were to be selected. 
Table 4-2. FBSR Critical Technology Elements Technical Readiness Level

\begin{tabular}{|c|c|c|c|c|}
\hline CTE & TRL & Scale & Fidelity & Environment \\
\hline FBSR system & 4 & $\begin{array}{l}\text { Laboratory: Laboratory- } \\
\text { scale tests accomplished }\end{array}$ & $\begin{array}{l}\text { Similar: Components match } \\
\text { pieces of the final } \\
\text { application }\end{array}$ & $\begin{array}{l}\text { Relevant: Simulant waste } \\
\text { processed and actual } \\
\text { waste tests ongoing }\end{array}$ \\
\hline $\begin{array}{l}\text { Reformer } \\
\text { subsystem }\end{array}$ & 5 & $\begin{array}{l}\text { Laboratory: Bench-scale } \\
\text { testing performed on } \\
\text { several simulants between } \\
2002 \text { and } 2009 \text {; ongoing } \\
\text { tests through } 2011\end{array}$ & $\begin{array}{l}\text { Pieces: Bench-scale } \\
\text { components closely match } \\
\text { pre-conceptual design } \\
\text { configuration }\end{array}$ & $\begin{array}{l}\text { Relevant: Actual tank } \\
\text { waste and additional } \\
\text { simulant testing will } \\
\text { continue in FY } 2011\end{array}$ \\
\hline $\begin{array}{l}\text { Offgas } \\
\text { treatment } \\
\text { subsystem }\end{array}$ & 4 & $\begin{array}{l}\text { Laboratory: Laboratory- } \\
\text { scale testing anticipated in } \\
2010\end{array}$ & $\begin{array}{l}\text { Pieces: Laboratory-scale } \\
\text { components closely match } \\
\text { pre-conceptual design } \\
\text { configuration }\end{array}$ & $\begin{array}{l}\text { Relevant: Actual tank } \\
\text { waste and additional } \\
\text { simulant testing will } \\
\text { occur in FY } 2011\end{array}$ \\
\hline $\begin{array}{l}\text { Monolithing } \\
\text { subsystem }\end{array}$ & 3 & $\begin{array}{l}\text { Laboratory: Laboratory } \\
\text { scale testing completed. } \\
\text { Engineering-scale testing } \\
\text { to be completed in } 2010\end{array}$ & $\begin{array}{l}\text { Pieces: Laboratory- and } \\
\text { engineering-scale } \\
\text { components closely match } \\
\text { pre-conceptual design } \\
\text { configuration }\end{array}$ & $\begin{array}{l}\text { Relevant: Actual tank } \\
\text { waste and additional } \\
\text { simulant testing will } \\
\text { continue in FY } 2011\end{array}$ \\
\hline $\begin{array}{ll}\text { FBSR } & = \\
\mathrm{CTE} & =\end{array}$ & zed & $\begin{array}{l}\text { ed steam reforming. } \\
\text { hnology element. }\end{array}$ & $\begin{array}{l}=\text { fiscal year. } \\
=\text { technology rea }\end{array}$ & adiness level. \\
\hline
\end{tabular}

Converting the FBSR mineral waste form to a monolith to provide compressive strength at Hanford would be a first of a kind application. RPP-RPT-48092, Rev 0 states that:

"While the present technical maturity of the monolithing process is at TRL 3, it is expected that final maturation should occur rapidly once monolithing becomes integrated with the more mature FBSR baseline technology. The binder selection used in monolithing is considered a low risk...".

\subsubsection{Process Scale up Requirements}

A FBSR facility for treating Hanford LAW has not yet been designed. If FBSR becomes one of the final candidates for treating LAW, then a conceptual design of a FBSR facility would be developed. It is not known at this time whether that will occur. Accordingly, the description of what a LAW FBSR facility may consist of is based on historical vendor information.

For preliminary estimation purposes, it is assumed that the design production capacity of the supplemental LAW immobilization facility, regardless of immobilization technology deployed, would be approximately $3700 \mathrm{MT}$ of Na per year. To provide that throughput capacity one or more FBSR facilities that together have approximately four 72-inch DMRs and associated CCRs would be required. Both represent scale-ups from the 45 -inch DMR that has been operating for a decade processing commercial nuclear wastes in Erwin, Tennessee and the 48-inch DMR in the INL IWTU scheduled to be commissioned in 2011. Scale-up correlations for the FBSR process 
can be derived from FBSR pilot and operations runs that have occurred using:

- The 6-inch DMR at the SAIC STAR Center in Idaho Falls, ID,

- The 15-inch DMR at the Engineering Scale Test Demonstration, Hazen Research, Golden, $\mathrm{CO}$, and

- The 45-inch DMR at the THOR Facility in Erwin, TN.

An artist's rendition of a dual 72-inch FBSR treatment train plant for Hanford LAW is depicted in Figure 4-7. That rendition does not include the monolithing facility for simplification.

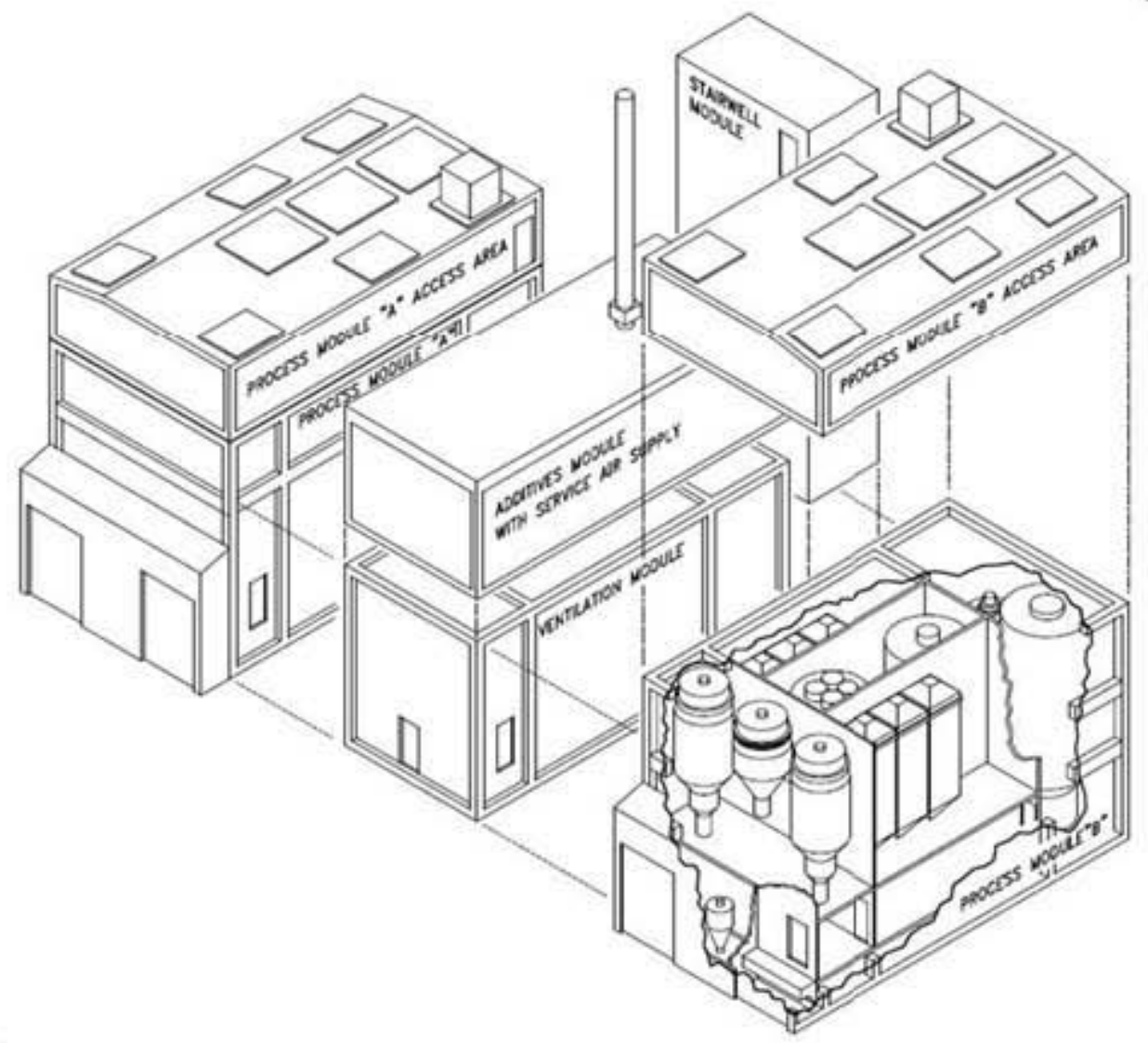

Figure 4-7. Artist Depiction of a Dual Train FBSR Treatment Facility for Hanford LAW

\subsection{PROCESS SAFETY CONSIDERATIONS/CONCERNS}

A hazardous categorization analysis in RPP-RPT-46668, Rev 0, Supplemental Treatment PreConceptual Engineering Review, determined that the FBSR facility would be a Hazard Category 3 facility. The major hazards related to FBSR include:

- Relatively high operating temperatures in the DMR and CCR,

- Superheated steam,

- Finely ground coal used in process, 
- Chemical burns due to leaks and spills during waste transfers,

- Process area fires from incidental combustible materials, and

- Presence of radionuclides and RCRA materials in the process (personnel and public safety and radioactive material confinement).

These are standard types of hazards and subject to mitigation by design, operating procedures, and standard safety protocols used at Hanford.

\subsection{COST CONSIDERATIONS/CONCERNS}

The major factors that influence the overall construction or operating costs for FBSR include:

- Hazard category 3 facilities generally have lower capital costs than hazard category 2 facilities (e.g., decreased shielding costs due to decreased source term),

- Relatively simple process design and moderate facility footprint,

- Container sizing that is cost effective, technically feasible and compliant with DOE, DOT, and NRC regulations,

- Capital and operating costs,

- Waste loading,

- Relatively inexpensive/readily available process consumables (e.g., clay, coal, large carbon steel waste containers),

- Activated carbon bed will likely be added to the off-gas train to mitigate the potential for mercury emissions, and

- Modular nature of process enables replication of design and fabricated process units, simplified spare parts inventory, and standardization of operating and maintenance procedures.

\subsection{WASTE FORM CHARACTERISTICS INCLUDING STRENGTHS, WEAKNESSES, OR UNCERTAINTIES}

The mineral waste form that would be produced if FBSR is selected for deployment at Hanford is thermodynamically stable and highly resistant to weathering. Scientists at PNNL (Pierce 2007) and at SRNL (Jantzen 2007) have reported the waste form to perform on par with glass waste forms based on surrogate Hanford LAW test runs.

The FBSR process is reported to capture very high percentages of radionuclides and key chemical constituents in the waste feed including:

- Over $99 \%$ of the ${ }^{99} \mathrm{Tc}$ and ${ }^{137} \mathrm{Cs}$ with Re as a surrogate for ${ }^{99} \mathrm{Tc}$ (Vora 2009).

- Over 95\% of the sulfur compounds and halogens (Jantzen 2004).

The mineral waste form needs to be converted to a monolith form prior to disposal in the IDF. The monolithic form is required to add compressive strength; not to enhance waste form durability relative to groundwater. The overall waste form/package needs to provide sufficient compressive strength to protect against future subsidence that could adversely affect disposal facility barriers to precipitation. The monolithic waste form will provide the compressive strength necessary to do that. Although monolith testing is still underway, virtually all of the monolith (binder) formulations tested would exceed IDF compressive strength requirements. 
The principal waste form uncertainty is its ability to sequester ${ }^{99} \mathrm{Tc}$ from the environment for tens of thousands of years. To date, all FBSR mineral waste form durability/leach testing have been based on surrogate wastes where Re was used as a surrogate for technetium. Testing at the BSR scale at SRNL in 2011 includes actual Hanford LAW that contains ${ }^{99} \mathrm{Tc}$ and that will be doped with Re. While it is known that sodalite cages can accommodate Re(VII) and Tc(VII) since their ionic radii are 51 picometers and 52 picometers, respectively, which may not be the case if Tc is in the Tc(IV) valence state which has a 50\% larger ionic radius. A likely key to technetium retention within sodalite cages will be controlling the reduction/oxidation (REDOX) conditions within the DMR such that technetium is in the Tc(VII) valance state in the zone where the minerals are formed.

While having technetium within a sodalite cage is a preferable outcome, it is not yet known whether having technetium otherwise chemically bound to the NAS minerals would also provide adequate protection since FBSR tests with ${ }^{99} \mathrm{Tc}$ were not conducted heretofore.

\subsection{OFF-GAS TREATMENT REQUIREMENTS AND CONSTITUENTS RELEASED}

Sulfur in the waste is captured within sodalite formed during mineral formation in the DMR. Other metals present in the waste also become part of the NAS minerals or spinels in the product stream. Accordingly scrubbers are not required for $\mathrm{SO}_{\mathrm{x}}$ or $\mathrm{NO}_{\mathrm{x}}$ removal from off-gas. Nitrogen compounds are reduced to form $\mathrm{N}_{2}$ which is released with the off-gas. Although some estimates indicate relatively high ${ }^{129} \mathrm{I}$ capture in the waste form for a thermal process, further material balance analyses are required to determine the extent to which iodine is captured. The principal off-gas constituents are water vapor, $\mathrm{CO}_{2}, \mathrm{O}_{2}$, and $\mathrm{N}_{2}$. Mercury, if present in the waste, would also follow the off-gas and would be treated using activated carbon absorbers. Similarly, if tritium is present in the waste feed it would be released with the water vapor in trace quantities. The process off-gas is MACT compliant at discharge.

\subsection{SECONDARY WASTE STREAMS}

The process does not generate secondary liquid wastes. Secondary solid wastes would be similar to those generated by other LAW treatment processes. These would generally include moderate volumes of:

- Personal protective equipment and maintenance/decontamination wastes,

- Failed/consumable equipment items, and

- Housekeeping wastes. 
RPP-48903, Rev 0

\subsection{INFORMATION NEEDS}

This section provides a list of existing data gaps that would be addressed in order to advance the FBSR technology to the next TRL if it were to be selected for further study at Hanford.

\subsection{CURRENT DATA GAPS}

In addition to waste form performance and qualification testing and analysis discussed previously, if FBSR were to be selected for further study additional testing and engineering analyses would be conducted to address questions related to:

- Establishing production-scale process controls points and strategies to ensure the desired product output and the actual product outputs coincide within acceptable limits;

- Determining how close to quantities that would be calculated by feed chemistry and stoichiometry can feed additives (e.g., clay and coal) be adjusted to minimize unreacted clay and coal while assuring the complete reaction of waste constituents to mineral endpoints;

- Determining whether carbon carried into process streams should be removed and, if so, to what levels and by what techniques and/or whether alternative means (non-coal) of introducing carbon into the system should be deployed;

- Determining the monolith binder chemistry that will be used to meet disposal requirements, ensure no degradation to the mineral waste form performance, and minimize environmental impacts;

- Designing the monolith facility to ensure production of the monolithed mineral waste forms within establish quality limits while achieving a TOE that will not impact FBSR throughput, and

- Establishing safety protocols and limits for each facility operation to ensure the safety of workers and the general public.

These and other issues will be addressed if FBSR is selected in the future in accordance with DOE Orders, National Environmental Policy Act (NEPA), and the TPA to advance towards deployment at Hanford. 


\subsection{RISKS AND BENEFITS}

The path forward with FBSR as a LAW waste treatment and immobilization technology includes any number of technical, regulatory, and programmatic risks that will need to be fully cataloged and addressed through mitigation strategies. This section provides a general overview of the types of project-related risks that may require mitigation if FBSR moves forward towards at Hanford. The level and detail of risks and the mitigation strategies to address them will increase if FBSR is selected to move forward. Benefits and principal advantages of the FBSR technology are also discussed.

\subsection{KEY TECHNICAL AND PROGRAMMATIC RISKS ASSOCIATED}

\subsubsection{Technical Risks}

Waste Form - The mineralized waste form required for Hanford LAW is not used in other commercial or DOE applications and has not been produced at production scales. At present, the principal technical risk is successfully qualifying the mineral waste form for deployment for Hanford LAW. In 2011 and 2012 additional tests will be conducted with actual Hanford tank wastes as previously described to resolve currently open questions regarding ${ }^{99} \mathrm{Tc}$ incorporation, obtain quantitative values for parameters in the kinetic release rate model, and select an appropriate binder to form final monoliths from the mineral product.

Engineering - As described in Section 5.1, there are engineering gaps that must be filled at appropriate times ranging from scale-up and process chemistry controls to bringing the monolithing process to a state of technical readiness adequate to proceed.

Safety - It should be anticipated that various safety questions will arise as designs progress and additional details solidify. Lessons learned from the FBSR projects at INL and SRS (which handle waste with substantially higher radionuclide concentrations than Hanford LAW) should benefit FBSR design and analysis activities at Hanford.

\subsubsection{Regulatory/Programmatic Risks}

Several parallel regulatory processes need to be successfully addressed for FBSR to be deployed at Hanford. These are briefly discussed below.

$R C R A / T P A$ - RCRA and the TPA will play heavily if FBSR is to be deployed at Hanford. RCRA and the TPA affect the deployment of FBSR in several ways. The primary risks may be associated with delays in executing RCRA/TPA regulatory processes. Those processes include a DET, a TV, and RCRA permits to construct, operate, and dispose of wastes.

$N E P A / S E P A$ - DOE must comply with NEPA requirements in order to develop, build, and operate any supplemental LAW treatment and immobilization facility. Similarly, the State of Washington must comply with its State Environmental Policy Act (SEPA) requirements prior to issuing permits for such facilities. There is a risk that the NEPA coverage provided by current NEPA activities will not be adequate if FBSR were to be selected. 


$$
\text { RPP-48903, Rev } 0
$$

DOE Order 435.1, Radioactive Waste Management - The key risk is obtaining a WIR determination or equivalent ${ }^{27}$ in time to support hot commissioning. Note that this same risk applies to the WTP.

A key programmatic risk is stakeholder and regulatory acceptance which is a common risk for any non-vitrification technology proposed for deployment at Hanford. A second programmatic risk is that since the mineral waste form and monolithing are first of a kind, the risk of currently unforeseen issues affecting cost and schedule can be greater. Conversely, this is more or less a common risk for all four candidate technologies since even if vitrification is selected; differences or enhancements between a 2nd LAW vitrification plant and the existing plant could be emerging.

\subsection{BENEFITS AND PRINCIPAL ADVANTAGES}

The principal advantages of FBSR are:

- It is a mature commercial petrochemical and commercial radioactive waste treatment technology.

- It produces a mineral waste form that preliminary information indicates will perform on par with LAW glass. Additional tests using actual Hanford tank wastes will provide further insights into its long-term waste form performance.

- The mineral product is formed using inexpensive additives and will be mixed with a binder and extruded into large carbon steel containers; thereby reducing consumables cost and product handling.

- It would be deployed in multiple modules, each with the same design and components, which reduces costs and simplifies operations/maintenance.

- It has low sulfur oxide $\left(\mathrm{SO}_{\mathrm{x}}\right)$ and nitrogen oxide $\left(\mathrm{NO}_{\mathrm{x}}\right)$ emission levels in off-gas due to reducing conditions during the reforming process.

- It does not generate secondary liquid wastes.

- It was selected by DOE to treat and immobilize sodium-bearing waste at the INL and SRS. Some engineering and analysis work from these deployments could potentially be applied to Hanford.

- It has moderate lifecycle costs based on rough order of magnitude information available to date.

\subsection{RISK MITIGATION}

The waste form testing and qualification work being performed in accordance with WP-5.2.12010-001, Rev 0.0, "DOE EM-31 Technology Development \& Deployment Program Task Plan, Fluidized Bed Steam Reformer Low-Level Waste Form Qualification”, will mitigate currently

\footnotetext{
${ }^{27}$ Washington could potentially petition Congress to become a covered state pursuant to Section 3116 of the Ronald W. Reagan National Defense Authorization Act for Fiscal Year 2005 (Section 3116) which provides an alternative (but similar) means for DOE to make a determination that the immobilized LAW is LLW.
} 
known waste form risks provided new information is confirmatory of information obtained from surrogate testing and preliminary binder testing. Engineering, safety, permitting, and programmatic mitigation activities will occur if FBSR is selected to proceed at CD-1 and additional engineering design and analysis activities are authorized. 
RPP-48903, Rev 0

\subsection{REFERENCES}

10 CFR Part 61, "Licensing Requirements for Land Disposal Requirement of Radioactive Waste," Code of Federal Regulations, as amended.

10 CFR 61.55, "Waste Classification," Code of Federal Regulations, as amended.

42 USC 6901, et seq., Resource Conservation and Recovery Act of 1976 (RCRA).

62 FR 8693, 1997, Record of Decision for the Tank Waste Remediation System, Federal Register, U.S. Department of Energy, February 1997.

70 FR 242, 2005, "Record of Decision for the Idaho High-Level Waste and Facilities Disposition Final Environmental Impact Statement", Federal Register, U.S. Department of Energy, pp. 75165 - 75172, December 19, 2005.

ANSI/ANS 16.1, 2003, Measurement of the Leachability of Solidified Low-Level Radioactive Waste, American Nuclear Society

ASTM B553-79, Test Method for Thermal Cycling of Electroplated Plastics, ASTM International.

ASTM WK84, Test Method for Measuring Waste Glass Durability by Vapor Hydration Test. ASTM International.

ASTM C1662-10, Standard Practice for Measurement of the Glass Dissolution Rate Using the Single-Pass Flow-Through Test Method, ASTM International. ASTM International.

ASTM G21-96, Standard Practice for Determining Resistance of Synthetic Polymeric Materials to Fungi, ASTM International.

ASTM G22-76, Standard Practice for Determining Resistance of Plastics to Bacteria. ASTM International.

ASTM C39/C39M, Standard Test Method for Compressive Strength of Cylindrical Concrete Specimens, ASTM International.

ASTM C1285-02, 2008, Standard Test Methods for Determining Chemical Durability of Nuclear, Hazardous, and Mixed Waste Glasses and Multiphase Glass Ceramics: The Product Consistency Test (PCT), ASTM International.

ASTM D6527-00, 2008, Test Method for Determining Unsaturated and Saturated Hydraulic Conductivity in Porous Media by Steady-State Centrifugation, ASTM International.

ANSI/ANS 16.1, Measurement of the Leachability of Solidified Low-Level Radioactive Waste, http://www.new.ans.org/store/i_240249.

Bernero 1993, Letter from R.M. Bernero, Director, Office of Nuclear Materials Safety and Safeguards, U.S. Nuclear Regulatory Commission, Washington, D.C., to J. Lytle, Deputy Assistant Secretary for Waste Operations, Office of Environmental Restoration and Waste Management, U.S. Department of Energy, Washington, D.C., March 2, 1993.

IDF 2004 CEES-0134, Rev. B, Integrated Disposal Facility Waste Acceptance Criteria, prepared by Columbia Energy and Environmental Services, Inc. for CH2M Hill Hanford Group, Inc., Richland, WA, August 18, 2004. 
C. Jantzen, N. Bibler, D. Beam, and W. Ramsey, 1994, "Development of an ASTM Standard Glass Durability Test, the Product Consistency Test (PCT), for High Level Radioactive Waste Glass," Proceedings of Spectrum 94 Nuclear and Hazardous Waste Management International Topical Meeting, Am. Nuclear Soc., 164-169.

DOE M 435.1-1, 1999, Radioactive Waste Management Manual, United States Department of Energy, Washington, D.C.

Ecology, EPA, and DOE, 1989, Hanford Federal Facility Agreement and Consent Order - TriParty Agreement, 2 vols., as amended, State of Washington Department of Ecology, U.S. Environmental Protection Agency, and U.S. Department of Energy, Olympia, Washington.

DOE/ER/14547-1, 2002, S. L. Brantley and Pantano, Dissolution Rates and Surface Chemistry of Feldspar Glass and Crystal, Final Technical Report, Pennsylvania State University, University Park, PA, June 2002.

Encyclopedia Britannica On-Line, Article on Crystal Physics, Long and Short Range Order in Crystals, http:/www.britannica.com/EBchecked/topic/145105/crystal/51804/Long-andshort-range-order.

EPA Test Method 1311, TCLP, Toxicity Characteristic Leaching Procedure, http://www.ehso.com/cssepa/TCLP_from\%20EHSOcom_Method_1311.pdf.

Gibbs 1996, Philip Gibbs, "Is glass liquid or solid", Physics FAQ, http://www.desy.de/user/projects/Physics/General/Glass/glass.html

Garman 2006, Garman, David K., DOE Headquarter, to Joel T. Case, DOE Idaho Operations Office, December 29, 2006, "Approval of Performance Baseline (Critical Decision-2) and the Associated Baseline Change Proposal, Long Lead Procurements and Site Preparation (Critical Decision-3B), and the Project Execution Plan for the SodiumBearing Waste Treatment Project."

Grumbly 1995, Settlement Agreement between the Department of Energy (Thomas P. Grumbly), Naval Nuclear Propulsion Program (Bruce DeMars), and the State of Idaho (Phillip E. Batt),' Consent Order signed October 17, 1995 by Edward J. Lodge.

Jantzen 1994, Development of an ASTM Standard Glass Durability Test, the Product Consistency Test (PCT), for High Level Radioactive Waste Glass, Proceedings of Spectrum 94 Nuclear and Hazardous Waste Management International Topical Meeting Am. Nuclear Soc., 164-169 (1994), C.M. Jantzen, N.E. Bibler, D.C. Beam, and W.G. Ramsey.

Jantzen 2004, "Characterization and Performance of Fluidized Bed Steam Reforming (FBSR) Product as a Final Waste Form", Jantzen, C.M., Ceramic Transactions 155, 319-329 (2004) .

Jantzen 2006a, "Durability Testing of Fluidized Bed Steam Reforming (FBSR) Waste Forms (U)", Jantzen, C.M., Lorier, T.H., Marra, J.C., and Pareizs, J.M., WM06 Paper \#6373, February 2006.

Jantzen 2007, Fluidized Bed Steam Reformed (FBSR) Mineral Waste Forms: Characterization and Durability Testing, Jantzen, C.M. , Lorier, T.H., Pareizs, J.M., and Marra, J.C., Scientific Basis for Nuclear Waste Management XXX, D. Dunn (Ed.), 379-386. 
Jantzen 2010, Fluidized Bed Steam Reformer (FBSR) Na-Al-Si (NAS) Waste form for Hanford $L A W$ and Secondary Waste, C.M. Jantzen, Savannah River National Laboratory, and E.M. Pierce, Oak Ridge National Laboratory, November 17, 2010 (PowerPoint Presentation to DOE Office of Environmental Management, Washington, D.C.).

Lutze 1988, "Radioactive Waste Forms for the Future," edited by W. Lutze and R.C. Ewing, Elsevier Science Publishers, Amsterdam, The Netherlands, 778pp, http://www.geo.lsa.umich.edu/relw/publications/books/radwasteform.htm

LWO-SPT-2007-00249, Rev. 1, 2007, "Technology Maturation Plan (TMP) Fluidized Bed Steam Reforming (FBSR) For Tank 48H Treatment Project (TTP)", Savannah River Site, Aiken, South Carolina, November 2007.

McGrail 1997, McGrail, B. P., P. F. Martin, and C. W. Lindenmeier, 1997, "Accelerated Testing of Waste Forms Using a Novel Pressurized Unsaturated Flow (PUF) Method', Mat. Res.Soc. Symp. Proc. 465:253-260.

NWPA 1983, Nuclear Waste Policy Act of 1983, Public Law 97-425; Stat. 2201.

NRC 1991, Technical Position of Waste Form, Rev. 1, United States Nuclear Regulatory Commission, Office of Nuclear Material Safety and Safeguards, Technical Branch, Division of Low-Level Waste Management and Decommissioning, Washington, D.C., January 1991.

Pierce 2007, "Accelerated Weathering of Fluidized Bed Steam Reformation Material Under Hydraulically Unsaturated Conditions", E.M. Pierce, PNNL, Materials Science and Technology, presented at ENERGY: Encapsulation and Immobilization of Hazardous and Nuclear Wastes Using Ceramics, Glass, and Other Materials, Detroit, Michigan, September 16-20, 2007.

PNWD-3288, 2003, Initial Evaluation of Steam-Reformed Low-Activity Waste for Direct Land Disposal, McGrail, B.P.; Schaef, H.T.; Martin, P.F.; Bacon, D.H.; Rodriguez, E.A.; McCready, D.E.; Primak, A.N.; Orr, R.D..

PNNL-SA-38162, 2006, "Synthesis and Structure of Perrhenate Sodalite", Mattigod, Shas V. ; McGrail, B. Peter ; McCready, David E. ; Wang, Li Q. ; Parker, Kent E. ; Young, James S., Pacific Northwest National Laboratory, Microporous and Mesoporous Materials, 91(1-3):139-144, April 15, 2006.

RPP-15834, Revision 0, 2001, Integrated Disposal Facility Risk Assessment, F.M. Mann, R.J. Puigh, S.H. Finfrock, R. Khaleel, M.I. Wood, CH2M Hill Hanford Group, LLC, Richland, WA, August 2001.

RPP-48395, 2011, A Joule-Heated Melter Technology for the Treatment and Immobilization of Low-Activity Waste, Rev. 0, Washington River Protection Solutions, LLC, Richland, Washington.

RPP-49062, 2011, Cast Stone Technology for the Treatment and Immobilization of Low-Activity Waste, Rev. 0, Washington River Protection Solutions, LLC, Richland, Washington.

RPP-48703, 2011, Bulk Vitrification Technology for the Treatment and Immobilizaton of Radioactive Waste, Rev. 0, Washington River Protection Solutions, LLC, Richland, Washington. 
RPP-48903, Rev 0

RPP-RPT-46668, Rev 0, 2010, Supplemental Treatment Pre-Conceptual Engineering Review, T.H. May, Washington River Protection Solutions, LLC, Richland, WA, August 19, 2010.

RPP-RPT-48092, Rev 0, 2010, Supplemental Treatment Program Technology Readiness Assessment, C.C. Haass, E.J. Dysland, E.L. Webb, and G.R. Golcar, prepared by AEM Consulting LLC for Washington River Protection Solutions, LLC, Richland, WA, December 2010.

RT-21-002, 2009, Report for Treating Hanford LAW and WTP SW Simulants: Pilot Plant Mineralizing Flowsheet, Prepared for US DOE Environmental Management Consolidated Business Center by THOR Treatment Technologies, LLC, Denver, CO, April 2009.

RT-21-002, 2009, "Report for Treating Hanford LAW and WTP SW Simulants: Pilot Plant Mineralizing Flowsheet", Prepared for US DOE Environmental Management Consolidated Business Center by THOR Treatment Technologies, LLC, Denver, CO, April 2009.

RT-21-002,2009, "Report for Treating Hanford LAW and WTP SW Simulants; Pilot Plant Mineralizing Flowsheet", THOR Treatment Technologies, Denver, CO, April 2009.

Ryan 2008, "Steam Reforming Technology Demonstration for Conversion of DOE SodiumBearing Tank Wastes at Idaho National Laboratory into a Leach-Resistant Alkali Aluminosilicate Waste Form - 8282", Kevin Ryan, J. Bradley Mason, Brent Evans, Vishal Vora (THOR Treatment Technologies), A. Olsen (CH2M WG Idaho), WM2008 Conference, February 24-28, 2008, Phoenix, AZ

SPD-07-195, 2007, Savannah River Site Tank 48H Waste Treatment Project Technology Readiness Assessment, Harmon, H.D., Berkowitz, J.B., DeVine, Jr., J.C., Sutter, H.G., and Young, J.K., U.S. Department of Energy, Savannah River Operations Office, July 31, 2007.

The Spinel Group of Minerals, 2010, Amethyst Galleries, Inc., http://www.galleries. com/ minerals/oxides/spinel.htm .

Vora 2009, Steam Reforming Technology Demonstration for Conversion of Hanford LAW Tank Waste and LAW Recycle Waste into a Leach Resistant Alkali Aluminosilicate Waste Form, Vishal Vora, Arlin Olson, Brad Mason, Brent Evans, Kevin Ryan (THOR Treatment Technologies), Hoyt Johnson (US Department of Energy, EM-21),WM '09 Conference, March 1-5, 2009, Phoenix, AZ

WHC-SD-WM-TI-699, Rev 2, 1996, "Technical Basis for Classification of Low-Activity Waste Fraction from Hanford Site Tanks", Westinghouse Hanford Company, Los Alamos Technical Associates, Inc., BNFL, Inc., September 1996.

Williams 2010, “2009 Pilot Scale Fluidized Bed Steam Reforming Testing Using the THOR (THermal Organic Reduction) Process: Analytical Results for Tank $48 H$ Organic Destruction - 10408”, M.R. Williams, C. M. Jantzen, P.R. Burket, C.L. Crawford, W.E. Daniel, C. Aponte and C. Johnson, WM2010 Conference, March 7-11, 2010, Phoenix, AZ.

WP-5.2.1-2010-001, Rev 0.0, 2010, "DOE EM-31 Technology Development \& Deployment Program Task Plan, Fluidized Bed Steam Reformer Low-Level Waste Form Qualification", U.S. Department of Energy, Washington, D.C., 2010. 
WSRC-TR-2005-00102, 2005, "Durability Testing of Fluidized Bed Steam Reformer (FBSR) Waste Forms for High Sodium Wastes at Hanford and Idaho", Pareizs, J.M., Jantzen, C.M., Lorier, T.H., U.S. DOE Report.

WSRC-STI-2006-00033 Revision 1, 2006, "Fluidized Bed Steam Reformer (FBSR) Product: Monolith Formation and Characterization", C.M. Jantzen, Savannah River National Laboratory, Aiken, SC, June 2006

WSRC-STI-2008-00268, 2008, "Mineralization of Radioactive Wastes by Fluidized Bed Steam Reforming (FBSR); Comparisons to Vitreous Waste Forms and Pertinent Durability Testing”, Jantzen", C.M., Savannah River National Laboratory, Aiken, SC 29808.

WTP-RPT-097, Rev 0 ,2003, "Initial Evaluation of Steam-Reformed Low-Activity Waste for Direct Land Disposal", McGrail, B.P.; Schaef, H.T.; Martin, P.F.; Bacon, D.H.; Rodriguez, E.A.; McCready, D.E.; Primak, A.N.; Orr, R.D. 
RPP-48903, Rev 0

\subsection{GLOSSARY OF TERMS}

Brunauer-Emmet-Teller (BET) Technique refers to a method of estimating the surface area of finely divided and porous solids that was developed by Stephen Brunauer, P.H. Emmet, and Edward Teller in 1938 while working on ammonia catalysts. It has since become the standard method used for determining the reactive surface area of irregular and porous solids and other materials not amenable to simple geometric measurement techniques.

Catalysts are substances that enable certain chemical reactions to proceed at a usually faster rate or under different conditions (as at a lower temperature) than otherwise possible.

Comprehensive Environmental Response, Compensation, and Liability Act (CERCLA) is a Federal "Superfund" enacted by Congress on December 11, 1980 to clean up uncontrolled or abandoned hazardous-waste sites as well as accidents, spills, and other emergency releases of pollutants and contaminants into the environment. Hanford is a CERCLA site.

Carbon Reduction Reformer (CRR) is the second reformer in the FBSR process train. It is used to oxidize off-gas from the Denitration Mineralization Reformer prior to processing through the off-gas system.

Fluidization refers to a process by which finely divided solids are suspended in a rising current of gas and take on the properties of a fluid rather than solids.

Denitration Mineralization Reformer (DMR) is the first reformer in the FBSR treatment train. The DMR converts the waste feed and additives into a mineral waste form.

Hanford Integrated Disposal Facility (IDF) is a LLW and mixed LLW disposal facility on the Hanford site that will be used to dispose of immobilized LAW as well as secondary wastes produced by tank farm and treatment operations.

HLVIT Standards (not an acronym) is a RCRA Universal Treatment Standard (UTS) that requires the vitrification of high-level radioactive waste generated during the reprocessing of fuel rods mixed with characteristic metal wastes. It was promulgated in the Third Rule at $55 \mathrm{FR}$ 22626 (June 1, 1990). The Third Rule stated that all the promulgated treatment standards in that rule for RCRA listed and characteristic wastes apply to the RCRA hazardous portion of mixed radioactive (high-level, TRU, and low-level) wastes, unless EPA has specifically established a separate treatability group for a specific category of mixed waste. Thus, that rule required that radioactive waste mixed with metal characteristic waste would have to comply with the LDR treatment standard for the metal characteristic waste, as well as any requirements set forth by the $\mathrm{NRC}$ for the radioactive component of the mixed waste.

High-Level Radioactive Waste (HLW) means (A) the highly radioactive material resulting from the reprocessing of spent nuclear fuel, including liquid waste produced directly in reprocessing and any solid material derived from such liquid waste that contains fission products in sufficient concentrations; and (B) other highly radioactive material that the [Nuclear Regulatory] Commission, consistent with existing law, determines by rule requires permanent isolation.

Low-Activity Waste $(L A W)$ refers to Hanford tank waste that has been treated to remove key radionuclides to the maximum extent technically and economically practical, converted to a solid form that meets 10 CFR Part 61.55 Class C concentration limits, and demonstrated through 


$$
\text { RPP-48903, Rev } 0
$$

a formal performance assessment to meet performance objectives comparable to those set forth in 10 CFR Part 61, Subpart C. LAW is a specific DOE-unique subset of low-level waste (LLW).

Low-Level Waste ( $L L W)$ is defined as radioactive material that is not high-level radioactive waste, spent nuclear fuel, or byproduct material as defined in section 11e(2) of the Atomic energy Act of 1954 (Source: Low-Level Radioactive Waste Policy Amendments Act of 1985).

Microporosity refers to extremely fine porosity of a solid material such that the pores are visible only with the aid of a microscope.

Non-Congruent Dissolution means that the chemical constituents in a waste form are released at different times. Non-congruent dissolution is associated with minerals and ceramics while congruent dissolution is associated with glass.

Performance Assessment (PA) refers to detailed analyses conducted to determine whether the protection provided by disposal sites, engineered barriers, and active and passive institutional barriers is adequately protective of human health and the environmental relative to applicable laws and regulations pertaining to the disposal radioactive and/or hazardous materials considering natural and human-caused processes and events that could affect that protection.

Polyhedron refers to a geometric solid in three dimensions with flat faces and straight edges.

Pyrolysis is a technical term that refers to the thermo-chemical decomposition of organic materials at elevated temperatures in the absence of oxygen. Pyrolysis typically occurs under pressure and at operating temperatures above $430^{\circ}$ Celsius.

Resource Conservation and Recovery Act (RCRA), enacted by Congress in 1976, is the principal Federal law in the United States governing the disposal of solid waste and hazardous waste. The Hanford tank wastes and systems used for the treatment of those wastes are regulated by the Washington Department of Ecology under RCRA.

Steam Reforming is a process that creates a reaction between high temperature steam and organic materials in an oxygen deficient environment. The reforming reaction breaks down the organic materials without combustion.

Stoichiometry refers to the quantitative relationships that exist between the reactants and products in chemical reactions. In a balanced chemical reaction, the relations among quantities of reactants and products typically form a ratio of whole numbers.

Subsidence in the context of this report refers to the creation of a surface depression within a waste disposal site that is created by the setting and compaction of materials within the site attributable to voids, compactable waste materials, and similar factors. Subsidence has the potential to diminish the long-term performance of surface barriers intended to reduce the amount of precipitation that enters subsurface areas and that could contribute to the mobility of soluble waste constituents.

Tetrahedra refers to a polyhedron composed of four triangular faces, three of which meet at each vertex, i.e., at each corner or intersection of the geometric shape. 
APPENDIX A
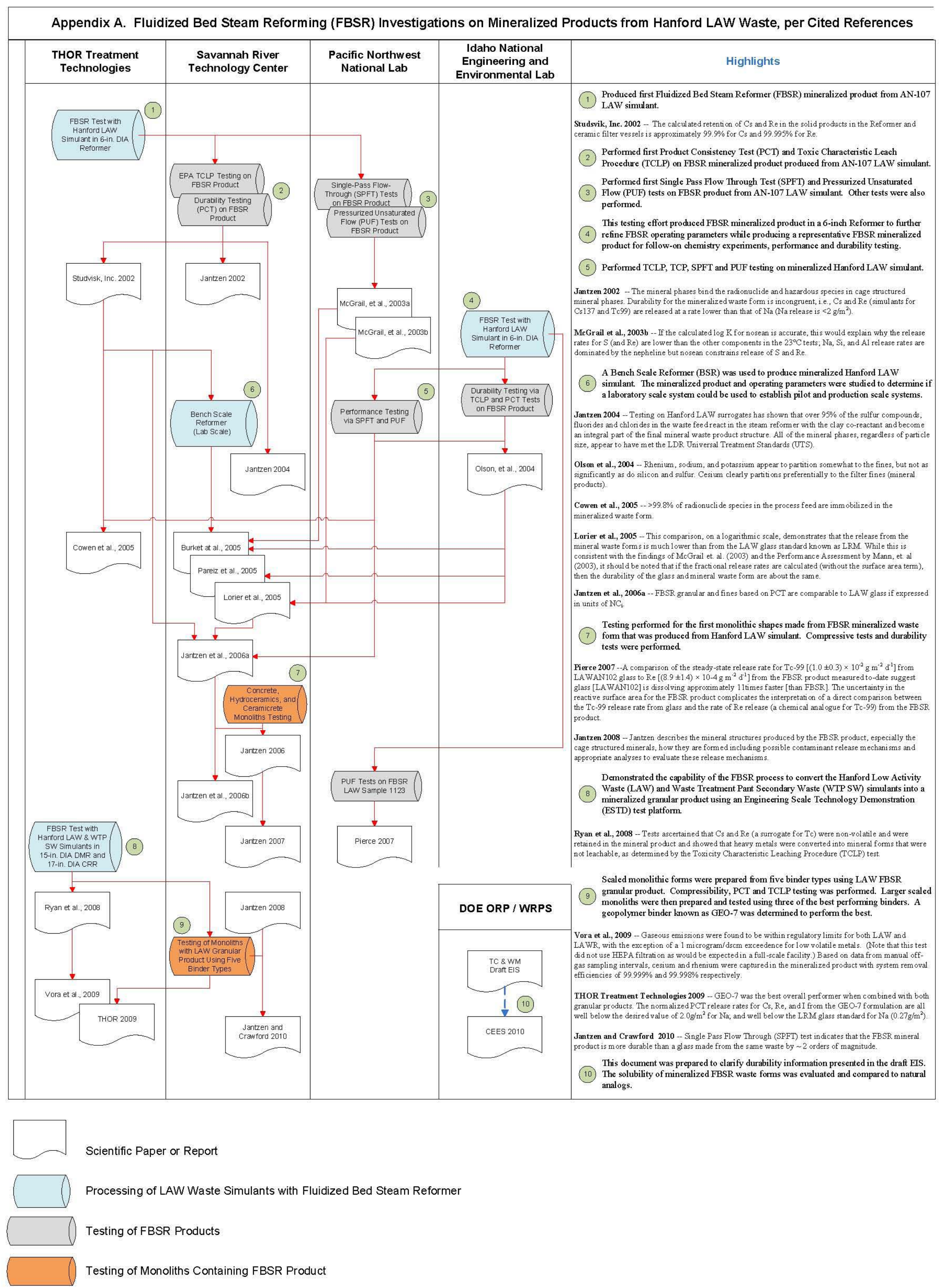


\section{Appendix A References}

Studsvik, Inc. 2002, Hanford LAW Waste THORsm Steam Reforming Denitration and Sodium Conversion Demonstration, Final Report, TR-SR01-1, Rev 0, Bechtel National, Inc, Richland, WA, Studsvik, Inc., Erwin, TN, 2002.

Jantzen 2002, Engineering Study of the Hanford Low-Activity Waste (LAW) Steam Reforming Process (U), WSRC-TR-2002-00317, Rev. 0, C. M. Jantzen, Savannah River Technology Center, Aiken, S.C., July 12, 2002.

McGrail 2003b, Laboratory Testing of Bulk Vitrified and Steam Reformed Low-Activity Waste Forms to Support a Preliminary Risk Assessment for an Integrated Disposal Facility, PNNL-14414, B. P. McGrail, J. L. Steele, E. M. Pierce, A. T. Owen, H. T. Schaef, D. M. Wellman, E. A. Rodriguez, Pacific Northwest National Laboratory, Richland, WA, September 2003.

Jantzen 2004, "Characterization and Performance of Fluidized Bed Steam Reforming (FBSR) Product as a Final Waste Form;"Jantzen, C.M. Ceramic Transactions 155, 319-329, 2004.

Olson 2004, Fluidized Bed Steam Reforming of Hanford LAW Using THORSM Mineralizing Technology, INEEL/EXT-04-02492, L. Olson, N.R. Soelberg, D.W. Marshall, G.L. Anderson, Idaho National Engineering and Environmental Laboratory, Idaho Falls, Idaho, November 2004.

Cowen 2005, "Steam Reforming Technology for Denitration and Immobilization of DOE Tank Wastes", Michael Cowen, J. Bradley Mason, Kevin Ryan, Duane Schmoker, WM-5451, WM '05 Conference, February 27-March 3, 2005, Tucson, AZ.

Lorier 2005, "Single Pass Flow Through (SPFT) Testing of Fluidized Bed Steam Reforming (FBSR) Waste Forms", Lorier, T.H., Pareizs, J.M. and Jantzen, C.M. U.S. DOE Report, WSRC-TR-2005-00124, 2005.

Jantzen 2006a, "Durability Testing of Fluidized Bed Steam Reforming (FBSR) Waste Forms (U)", Jantzen, C.M., Lorier, T.H., Marra, J.C., and Pareizs, J.M., WM06 Paper \#6373 (February 2006).

Pierce 2007, "Accelerated Weathering of Fluidized Bed Steam Reformation Material Under Hydraulically Unsaturated Conditions", E. M. Pierce, PNNL, Materials Science and Technology 2007, September 16 - 20, 2007, Detroit, Michigan.

Jantzen 2008, Mineralization of Radioactive Wastes by Fluidized Bed Steam Reforming (FBSR); Comparisons to Vitreous Waste Forms and Pertinent Durability Testing, Jantzen, C.M., WSRC-STI-2008-00268, 2008.

Ryan 2008, "Steam Reforming Technology Demonstration for Conversion of DOE SodiumBearing Tank Wastes at Idaho National Laboratory into a Leach-Resistant Alkali Aluminosilicate Waste Form - 8282", Kevin Ryan, J. Bradley Mason, Brent Evans, and Vishal Vora, (THOR Treatment Technologies), A. Olsen (CH2M WG Idaho), WM2008 Conference, February 24-28, 2008, Phoenix, AZ.

THOR Treatment Technologies 2009 , Report for Treating Hanford LAW and WTP SW 


\section{RPP-48903, Rev 0}

Simulants; Pilot Plant Mineralizing Flowsheet, RT-21-002, THOR Treatment Technologies, Denver, CO, April 2009.

Jantzen and Crawford 2010, Mineralization of Radioactive Wastes by Fluidized Bed Steam Reforming (FBSR): Radionuclide Incorporation, Monolith Formation, and Durability Testing - \#10467,C.M. Jantzen and C.L. Crawford, C.M. Jantzen and C.L. Crawford, Savannah River National Laboratory, Aiken, SC 29808, Waste Management 2010, Phoenix, AZ, February 2010. 